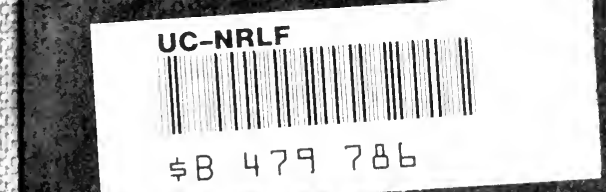




\section{GIFT OF JANE K.SATHER}
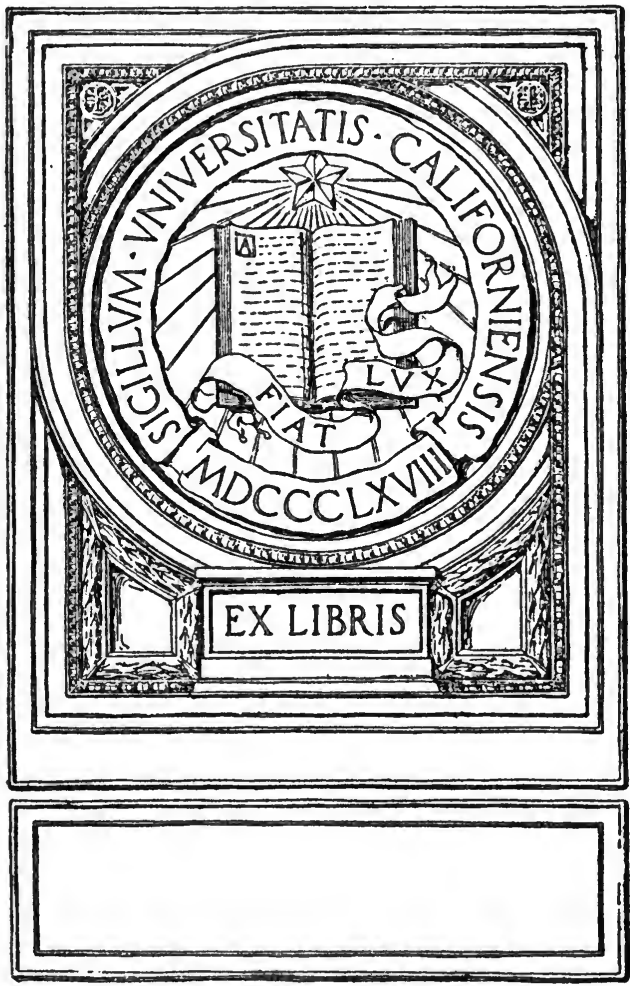
Digitized by the Internet Archive in 2007 with funding from Microsoft Corporation 



\section{THE PATRIMONY OF THE ROMAN CHURCH}




\section{CAMBRIDGE UNIVERSITY PRESS}

C. F. ClAY, MANager

LONDON : FetTer LANe, E.C. 4

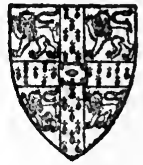

NEW YORK: G. P. PUTNAM'S SONS

BOMBAY, CALCUTTA, MADRAS: MACMILLAN AND CO., LTD. TORONTO: J. M. DENT AND SONS, LTD.

TOKYO: THE MARUZEN-KABUSHIKI-KAISHA

All rights reserved 


\title{
THE PATRIMONY OF THE ROMAN CHURCH IN THE TIME OF, GREGORY THE GREAT
}

\author{
BY \\ EDWARD SPEARING, B.A., LL.B. \\ (LIEUTENANT, KING'S OWN ROYAL LANCASTER REGIMENT)
}

EDITED BY

EVELYN M. SPEARING, M.A. (LoND.) (LATE FELLOW OF NEWNHAM COLLEGE, CAMBRIDGE)

\section{CAMBRIDGE}

AT THE UNIVERSITY PRESS

I 9 I 8 


$$
\begin{aligned}
& 3 \times 1950 \\
& 57
\end{aligned}
$$

औओ

Fistany-Sather 


\section{PREFACE}

E DWARD SPEARING was killed in action near Delville Wood on September II, I9I6, at the age of twenty-six. He was educated at the Perse Grammar School, under Dr W. H. D. Rouse, and at Emmanuel College, Cambridge, where he studied History and Law. He was a Scholar of his college, and obtained a first class in Part I of the Historical Tripos, I9Io, and a second class in Part II, IgIr. In I9I2 he was placed first in order of merit in Class II of Part II of the Law Tripos. For the next two years he continued the study of law, and was articled to a Cambridge firm of solicitors.

As soon as war broke out he volunteered for service, and was gazetted to a commission in the King's Own Royal Lancaster Regiment on August I8, I9I4. He trained with his battalion in England till the following spring, and in May, I9I5, went with it to France. In August of the same year he was promoted-lieutenant. He saw heavy fighting round Festubert that summer, and one of his brother officers wrote to a mutual friend: "Spearing is in great form, and is extraordinarily good in the trenches and when there is trouble afoot. He knows everything about the lie of the land and can size up a position in an instant. His platoon thinks the world of him, and during the engagement we were in I am told he did awfully 
well." On December 30, I9I5, he was wounded in the right shoulder by a rifle grenade, and was sent to hospital in England, and then home on sick leave. He made an excellent recovery, and, when he was given the choice of remaining in England with the reserve battalion, preferred to return to the front. For some time he was Regimental Intelligence Officer, and his fearlessness and cleverness at the job caused him to be given the post of Brigade Intelligence Officer. He had only held this post for a short time before an attack of trench fever caused him to be sent to hospital for some weeks. During his illness his battalion suffered very heavily in the Somme fighting, and though the Brigade Staff wished him to return to them he could not be spared from the trenches. He was given the command of a company, though he had not yet been gazetted captain, and on the morning of September II, I9I6, he was ordered to lead it in an attack against heavy odds. In the fighting that ensued he was reported missing, but a few days later his body was found near the German trenches. He had been last seen some yards in front of his men, when the attack was held up. A junior subaltern who belonged to his company and who was wounded in the same fighting wrote thus of him: "The King's Own have lost a splendid officer and all ranks will regret his death. As the officer commanding the company to which I was attached I saw in the few days I was with him how he put forth all that was best in him for his company, battalion, and the end to which we are all aiming... 
Odds were against us, but he unflinchingly led out his company on the morning when so many gallant fellows gave up their lives." His colonel died of wounds a few days afterwards, but the officer who then took command wrote: "Spearing was commanding the company and pulling it together awfully well. $\mathrm{He}$ was a splendid fellow and had no idea of fear."

Brilliant as his abilities certainly were, perhaps his most distinctive characteristic was his genius for friendship. His simplicity, modesty and gentleness won the love and admiration of very different types of men. One of his Cambridge friends wrote of him: "I can truly say I think he was one of the best liked men in college. He seemed to know the most diverse kinds of people, and yet they all liked him and esteemed him." "I loved him as much as if he had been my brother," said another Emmanuel man. "Stauncher friend no man could have had, nor more delightful companion," was the testimony of a college friend who himself fell in the Somme fighting a few weeks later. The Master of Emmanuel wrote of him: "In college everyone liked him because he was so straight, and everything that a scholar ought to be," and a graduate of another college described him as "a thorough sportsman of the best type."

When he entered the army he carried with him this power of making friends. "He was one of my best pals. We all miss him very greatly," said an officer whose friendship with him dated from the time when they both joined the battalion as junior subs. It would take too much room to insert here 
the tributes of other brother-officers, some of whom had known him previously at school or college, but it should be noted that the feeling he aroused was not the mere surface-popularity of an ordinary "good fellow." "We were such close friends as I think rarely happens," wrote the friend who knew him best, "and the soldiering we had together strengthened the tie perhaps more than anything else could have done." He endeared himself greatly to those with whom he was billeted, and even in the last few weeks of his life, during his convalescence from trench fever, he made new friendships.

This monograph on the Patrimony of the Roman Church was written by my brother during the years I9I2-IgI4, when he was between twenty-two and twenty-four years old. He had then just left college and was studying law with a view to becoming a solicitor, and it was only his spare time that he could devote to the writing of this essay. It was, however, a subject in which he had been interested during his college days, when the study of early church history occupied much of his time, and Gregory the Great had long been one of his favourite historical characters.

As originally planned by my brother the essay was to have had a wider scope, and to have furnished an account of the history of the Roman patrimony during the first six centuries A.D. When, however, his papers were examined after his death, it became evident that a considerable amount of further work would be necessary if this wider survey were to be 
completed satisfactorily. He himself had been aware that the essay was not ready for publication, and had remarked when he was home on leave that certain portions of it needed re-writing. Under these circumstances it seemed better to narrow the scope of the book and to confine it to the period of Gregory the Great, with which he was more thoroughly conversant than with the earlier period. I have therefore compressed a number of pages dealing with the patrimony in earlier times into the short sketch of its development given at the beginning of Chapter I, and have omitted various references to certain disputed points, such as the history of the payment of tithes, which needed much fuller treatment if they were to be introduced at all. The book as it stands, therefore, consists entirely of my brother's work, but in a somewhat shortened form, and my own share in it has been confined to this compression and to the addition of a certain number of references and notes. The most valuable part of the work certainly consisted in the careful study which my brother had made of all references to the patrimony in Gregory's letters, and of the comments of Ewald and Hartmann, Grisar, and Zaccaria on these references, and this has been retained in full.

My thanks are due to Mr G. G. Coulton, of S. Catharine's College, Cambridge, for his help and unfailing kindness to me in the work of revision, and also to the Rev. W. H. Frere, D.D., of the Community of the Resurrection, Mirfield, who made some valuable suggestions. I should like also to express my gratitude 
to the staff of the University Press, for the help which they have given me in proof-reading-a task which, owing to my present duties in a military hospital, I have not been able to perform as carefully as I should have wished.

Doubtless there are many imperfections in the book as it now stands, but I think that there are many students of the period who will welcome this attempt, however imperfect it may be, to bridge a gap which exists in the English historical studies of this time, and that they will be glad to have this small volume -which might have been the firstfruits of a plenteous harvest-from one who in his life sought Truth carefully and diligently, and in his death loved liberty more than life.

EVELYN M. SPEARING

I3 February, 1918. 


\section{CONTENTS}

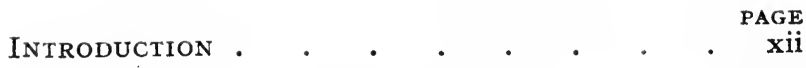

CHAPTER I

The Growth of the Patrimony and its extent UNDER GREgoRY THE GREAT . . . . . I

CHAPTER II

The Government of the Patrimony . . . 2 I

CHAPTER III

The Organisation of the Patrimony . • 40

CHAPTER IV

Relations with the State . . . . . . 93

\section{CHAPTER V}

The Collection of the Revenue • • • Io7

\section{CHAPTER VI}

The EXPENDItURe of THe Income

II4

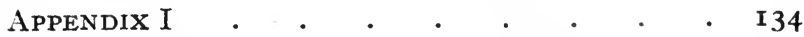

APPENDIX II . . . . . . . . . $\quad$ I 38

INDEX $\quad . \quad+\quad \cdot \quad \cdot \quad \cdot \quad \cdot \quad \cdot \quad \cdot$ I 40 


\section{INTRODUCTION}

THE consideration of the organisation and ad1 ministration of the Patrimony of the Roman Church forms a subject nearly as vast in its extent as was that patrimony itself in geographical area, and one as fruitful in thorny questions and unsolved problems as was the land itself in the more material fruits of the earth. But while the lands and territories which formed the inheritance of S. Peter are thickly populated, covered with flourishing towns and villages, and accurately mapped down to the last square foot of ground, the space which the patrimony occupies in the realm of history is yet largely unexplored, only its main outlines are known, and much remains to be discovered before History can claim this territory as another slice added to her realms from the vast terrae incognitae which still remain.

The possession by the Roman Church of that great collection of estates, rents and rights which formed the Patrimony of S. Peter, though it is a subject which has received but little attention, was nevertheless a fact of great importance, for it formed the material (as opposed to the moral) foundation on which rested the fabric of the medieval Papacy. The ownership of this enormous mass of scattered estates and districts became in time insensibly converted into sovereignty; and though the Papacy in 
the end lost most of its outlying estates in Africa, the Balkans and Sicily, yet the possession of these afforded a precedent, and their loss a reason, for the acquisition from the generosity of Frankish kings of new provinces in Italy. The sovereignty of these provinces and estates gave to the Papacy an independence and power which it could never have attained had the Pope remained the subject of any temporal ruler. It was the possession of independence and temporal power which alone rendered the position of Hildebrand or Innocent III possible. Had the Pope been in any real sense the subject of the Emperor, or had the imperial power in Rome been anything less than a shadow, it can hardly be doubted that the position of the Pope would not have differed much from that of the Patriarch of Constantinople or greatly exceeded that of an archbishop of Cologne or Mainz. But while it was the conversion of the Pope from a landlord into a sovereign, and the consequent possession of temporal power, which rendered the mighty position of the medieval Papacy possible, it ${ }_{2}$ was also the possession of the patrimony which, in the main, had protected the Pope from the aggression of temporal kings and enabled the Papacy to preserve and assert that independence which in its early stages was often threatened. It was due to the revenues and provisions drawn by the Church from Sicily that Gregory the Great was enabled to defend Rome successfully against the Lombards, and Gregory II to repel an even more dangerous Lombard attack under King Luitprand. If either of these attacks had

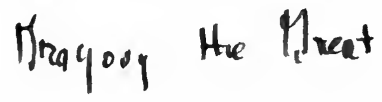


succeeded, Rome, and much of what Rome stood for, would have gone, and the independence of the Papacy with it.

It was not only in temporal matters that the possession of the patrimony rendered the Papacy powerful and independent. The fact that the component parts of the patrimony were scattered over many districts and countries rendered necessary the residence of papal representatives in these places and constant communication with Rome, and this-as will be shown later-afforded many opportunities for papal interference in the ecclesiastical affairs of these districts; while the papal representatives spared no pains to increase the prestige of Rome and assert her authority wherever possible. The civil service-to use a modern parallel-which the government of the patrimony thus rendered necessary was a potent influence in increasing and maintaining her spiritual authority in the west, and formed an instrument ready to hand for that undermining of episcopal authority which everywhere accompanied an increase of papal influence.

The existence of the patrimony of the Roman Church is thus a fact of the first importance in explaining the development of the Papacy, and there can be but little doubt that the modern papal apologists of the temporal power, however much they may be in error in applying their conclusions to the present day, are at any rate not far from the truth when they assert that during the past ages of history the temporal power of the Papacy has been a 
condition precedent to the exercise of its spiritual authority.

Since the patrimony of the Roman Church is thus a fact of great importance, it may be presumed that a discussion of its origin, and organisation, even though neglecting the larger issues above referred to, may yet be of interest from the importance of its subject, as the childhood of great men and even the trivialities of their daily life become important through their future achievements.

This alone, perhaps, might hardly seem to warrant a detailed account of the patrimony, its organisation and government, but such an account and discussion is valuable not only for the importance of its subject matter: it throws light in addition on many other facts and problems.

The papal patrimony formed an integral part of the imperial portion of Italy, and the details of its administration and its condition at any one period give a valuable insight into the general condition of Italy. The documents which are authorities for the administration of the patrimony are also frequently. authorities for the general history of Italy. This is especially true of the letters of Pope Gregory the Great and many details of importance for general Italian history can be gleaned even from those letters which deal more specially with the patrimony.

But it is on the social conditions of the time that a discussion of the conditions prevailing in the patrimony naturally throws most light. The position of the cultivators of the soil or "coloni" and "servi," 
of the farmers or "conductores," and of the independent land-owners or "possessores," is fully illustrated in the documents dealing with the patrimony; and in fact these documents are almost the only sources of information on these subjects. Much light is also thrown on the land holding system of the time and on the fiscal methods of both the Church and the Empire. And occasionally one of these documents will throw a beam of light through the almost impenetrable darkness that hides that far-off time and show us one or two sharply defined scenes from the daily life of the people.

But perhaps the most interesting subject among the many which a discussion of the patrimony brings into prominence is that of the relation of the Church to the poor and the efforts made by the Church to build up a system of organised poor relief. This is a subject which has been almost entirely neglected by scholars, a rather strange fact in view of the great intrinsic interest of the subject itself and the importance which the problem of poverty and systematic poor relief has assumed in the present day; but a comprehensive history of sociological effort is one among the many histories which still remain to be written.

Much information is also to be gleaned from the documents dealing with the patrimony on the relations of the Church to the decaying Byzantine Empire. A lurid light is thrown on the incompetence and rapacity of the imperial officials, and Gregory I's letters show a great contrast between the miserable 
inefficiency of the imperial government and the smooth and efficient working of the papal administration. It is quite evident from these letters that the Church was bound to increase at the expense of the State and that the papal ownership of land could not but develop into sovereignty. Contemporaneous with this decline of imperial government is seen the beginning of civic independence and the first foreshadowings of the coming feudalism.

Enough has been said to show that a discussion of the origin and organisation of the patrimony of the Roman Church is not without interest or value, but very few writers have treated the subject with any fulness. No English writer, so far as I am aware, has dealt with the patrimony at all, with the exception of the Rev. F. H. Dudden, who in Volume I of his book on Gregory the Great devotes twenty-four pages to its condition during Gregory's papacy. There exist, however, certain treatises on the subject by foreign authors, of whom Borgia, Zaccaria and Grisar are the most noteworthy'. Borgia's treatise deals almost entirely with the history of the patrimony in the Two Sicilies from the year 800 onwards, and therefore touches only incidentally on the subject of the present essay. Zaccaria's work covers an earlier period, and has proved extremely useful and valuable.

1 Borgia, Breve istoria del dominio temporale nelle due Sicilie. Grisar, Rundgang durch die Patrimonien des heiligen Stuhles um das Jahr 600, and Verwaltung und Haushalt der päpstlichen Patrimonien um das Jahr 600, in Zeitschrift für katholische Theologie, 1877.

Zaccaria, De rebus ad historiam atque antiquitates Ecclesiae pertinentibus, Dissertatio x. De Patrimonio. 
But it is marred in places by the fact that the writer is not altogether unprejudiced and takes up a somewhat partisan attitude on certain disputed points of minor interest, and he is at times too apt to allow the desire of making points against an adversary to run away, with him. Thus he spends quite a disproportionate amount of time in defending the view that the patrimony, even in the time of Gregory I, included whole towns, and necessitated as a consequence the exercise of practical sovereignty over such towns -a view controverted by Muratori, Johannes de Johanne and other writers. $\mathrm{He}$ also spends too much time on the discussion of small points, such as the proper succession of rectors in the various patrimonies, while he passes over the more important matters connected with the revenue and administration with but little attention.

The two articles by Dr Hartmann Grisar in the Zeitschrift für katholische Theologie are of the very greatest interest, especially as coming from an acknowledged authority on Gregory the Great. I have frequently relied on the first article in my treatment of the various estates forming the patrimony. In the second article the section dealing with the officials of the patrimony has formed the basis of my chapter on the organisation of the patrimony. The position of the "coloni" on the church estates, and the protective measures undertaken by Gregory on their behalf are very ably dealt with, as are also the condition of the church slaves and the attitude of the Church towards slavery. The position of the 
"conductores," however, and their relations with the "coloni" are passed over very lightly. If it be not presumptuous to say so, it seems to me that, like Zaccaria, Grisar has spent rather too much time on details, especially on the names of the rectors who presided over the various patrimonies-a subject treated very fully in the first of Grisar's articles, which is largely borrowed, as he admits, from Zaccaria's book-while he gives but scant notice to certain more important matters, such as the expenditure of the revenue and the question of poor relief. It must be noted, however, that all these three writers are members of the Roman Church, and priests as well, and therefore matters of ecclesiastical organisation and rights, which may seem to others of but subsidiary importance, naturally bulk larger in their eyes in discussing a matter such as this.

There are two other authors whom I have found useful in a few points. The book on the Roman Campagna by G. Tomassetti contains one or two useful pages dealing with the sub-divisions of the patrimony, the "massae" and "fundi," and the essay by Savigny entitled Der römische Colonat in Volume II of his Vermischte Schriften has been very valuable in connection with the whole question of the colonate.

\section{EDWARD SPEARING}





\section{CHAPTER I}

\section{THE GROWTH OF THE PATRIMONY AND ITS}

\section{EXTENT UNDER GREGORY THE GREAT}

W

$\mathrm{E}$ possess very little authentic information as to the origin and growth of the Patrimony of the Church during the first four centuries. It is not until the pontificate of Gelasius (492-496) that references to the Patrimony in papal letters or other documents become frequent, and when in the letters of Gelasius the veil is at last lifted, it is only to show us a Patrimony already fully developed, and an organisation similar even in small details to that which prevailed a century later under Gregory the Great. This almost unbroken silence maintained by the early Christian writers with regard to the estates and worldly wealth possessed by the Church, though it may be regretted by the historian, is yet hardly surprising. Until the time of Constantine the various churches were bodies unrecognised and even proscribed by law, and it would plainly have been an act of great folly on the part of its members to call attention in any way to the landed property which the Church possessed. That references to the Patrimony are not more numerous after the recognition of Christianity by Constantine is matter for more surprise, but it must be remembered that during the whole of the fourth century men's minds were occupied by the great contest between Arianism and

S. P. 
Catholicism to the exclusion of all smaller matters, and the Church had not as yet reached a position of so secure importance as to ensure the preservation of even routine and business documents referring to its affairs.

It is possible, however, to piece together a certain amount of information from scattered allusions and to make some reasonable conjectures concerning the origin and early growth of the Patrimony ${ }^{1}$. Thus it may be shown that the Christian Church in Rome was distinguished even in early days for its wealth and generosity. Eusebius quotes a splendid eulogy contained in a letter written by Dionysius, bishop of Corinth, to the Romans in the year I6r: "This has been your custom from the very beginning of our religion to shower benefits of every kind on all the brethren, and to send help for the necessities of life to many churches in many cities ${ }^{2}$."

It is probable that these gifts were raised at first by subscription among the members of the Church, but it would be natural, as soon as the Church attained a stable constitution and the episcopal organisation had become permanent, that men should wish not merely to subscribe for special objects, but to make over property to the Church, by deed or will, in order to form

1 For a list of authorities dealing with the early history of the Patrimony and for a discussion of its later development, see the article on Patrimonium Petri in Hauck-Herzog, Realencyklopädie für protestantische Theologie und Kirche, vol. xIv. pp. 767 seq. and that on Kirchenstaat in Wetzer-Kaulen, Kir. chenlexikon oder Encyklopädie der katholischen Theologie, vol. vir. pp. 668 seq.

2 Euseb, Hist. Eccles, lib. Iv. c. 23. 
a permanent fund for the exercise of hospitality and the relief of the poor, and the control of this property would naturally be in the hands of the bishop.

The persecutions which the Church endured during the first three centuries did much to prevent the acquisition of permanent property, especially land, since during that time it was always liable to confiscation. The conversion of Constantine gave a great impetus to the growth of the Church, and converts flocked into it from all sides. An edict of the Emperor $^{1}$ now made it legal for property to be left to the Church, and it is from this date that the great expansion of the Patrimony begins. Enormous donations seem to have been made to the Church by the Roman nobles, and it was during the fifth century, probably, that these gifts reached their largest extent, as by that time the influence of the Church and its hold over the minds of men had grown very great, while the unsettled conditions prevailing in Italy rendered the possession of property in many cases a burden rather than a profit ${ }^{2}$.

It seems probable that in addition to these private

1 Cod. Theod. xvi. 2. 4.

2 Some persons seem to have "commended" themselves to the Church, that is made over their lands to the Church, on condition of receiving an annuity during their lives. See the case of the merchant Liberatus mentioned in Greg. Reg. I. 42. Even where land was made over absolutely to the Church a nominal reservation of the usufruct was made for a short period. Examples of deeds of gift of this period are not numerous, I give one good example of a gift to the Church of Ravenna in Appendix $\mathrm{I}$. I have not referred to the conveyance made by Gregory to the monastery of S. Andrew on the Coelian (given in Greg. Reg.) as it is supposed by some to be spurious. 
donations the Church also benefited by the imperial bounty. The donation of Constantine and the Acta Sylvestri must of course be rejected as spurious, but Zaccaria has noted that there is in many ways a curious parallelism between the Patrimonium Ecclesiae and the Patrimonium Principis, and it seems not unnatural to suppose that after the removal of the imperial court to Constantinople portions of the imperial patrimony may have been made over to the Church. It may be noted in this connection that the Liber Pontificalis records that on the condemnation of Bassus, the false accuser of Pope Xystus, his lands were declared forfeited and given by the Emperor Valentinian to the Church ${ }^{1}$.

The Patrimony was also increased by a small but continuous stream of goods and estates which came to it on the death of certain church dignitaries, monks, and slaves. In the case of bishops all property acquired by them after elevation to their sees, except that coming to them by will from relatives, belonged to the church over which they presided, but this rule did not apply to priests or the inferior clergy ${ }^{2}$. As to slaves belonging to the Church, their "peculium" or property, as in the case of slaves of private owners, belonged in law absolutely to their master ${ }^{3}$, and they were consequently incapable of making a valid will. Occasionally, to adopt S. Gregory's own words, "the purse of the Church was defiled by ill-gotten gains."

1 Lib. Pont. ed. Duchesne, vol. r. p. 232.

- Cf. Greg. Reg. v. 23, Ix. 8, I37, 142.

3 Note the gift of their "peculium" made by Gregory I to two slaves on their manumission. Greg. Reg. VI. I2. 
In his famous letter to Peter the sub-deacon ${ }^{1}$ Gregory refers to the attempts made to claim for the Church the property of church farmers (conductores) who died intestate, and he forbids for the future such attempts to deprive the relatives of their succession. He refers in another letter ${ }^{2}$ to the many estates unjustly seized during the previous ten years in Sicily by Antoninus, the defensor of the patrimony there, and orders them to be at once restored to their owners, and there are frequent references in his letters ${ }^{3}$ to complaints made respecting the rapacity of the church officials. Of all these sources, however, the first-mentioned-the gifts of the faithful-was by far the most important, and it was to this that the Church of Rome rightly looked in later times as the origin of its wealth.

Though there can be little doubt as to the great extent and wide distribution of the estates belonging to the Roman Church during the fifth and sixth centuries, detailed information as to their situation is very meagre 4 , and it is not until the end of the sixth century that the information contained in the letters of S. Gregory enables a fairly comprehensive survey of the estates of the Church to be taken.

These estates were known collectively as the Patrimonium Ecclesiae or Patrimonium S. Petri, but the use of the word patrimony was not confined to this

1 Greg. Reg. I. 42.

2 Ibid. I. 39 a.

3 Ibid. 1. 53, 63, 71, IX. I92.

4 There are frequent references to the Patrimony in the letters of Pope Gelasius (492-496) and some years later in those of Pelagius I, but the only papal estates mentioned by name, so far as I am aware, are those in Dalmatia (Jaffé, Reg. 686), Picenum (ibid. 633, 953), and Gaul (ibid. 943, 947). 
sense. For purposes of administration the estates situated in different provinces or countries were grouped together to form large territories, and to each of these the term was applied. These patrimonies were distinguished from each other by the addition of the name of the province in which they were situated or of the central town round which they were grouped. Thus the estates situated in Apulia formed the Patrimonium Apuliae, and those near Palermo the Patrimonium Panormitanum.

The largest portion of the Church estates was situated, as was natural, in Italy and Sicily, and the Sicilian patrimony was probably the largest and most important of all in the time of Gregory the Great. Unlike Italy, Illyria, or Gaul, where other patrimonies were situated, Sicily had not suffered at all from Lombard or Slav invasions, and had enjoyed unbroken peace since the end of the Gothic war. Moreover the island was noted for its fertility, and it had been one of the chief granaries of Rome ever since the days of the Republic. The imperial grants of corn to the city still continued in the time of Gregory and were drawn from Sicily ${ }^{1}$, and in addition the Roman Church purchased annually a large amount of corn from the cultivators of its estates there ${ }^{2}$.

The extent of the Church estates in Sicily must háve been very great, and they seem to have been situated in every part of the island. Mention is made in Gregory's letters of estates in the districts of Messina, $\checkmark$

1 Greg. Reg. I. 2, IX. I I5.

2 Ibid. I. 42. 
Catane $/$ Syracuse, Agrigentum $/$ and Palermo $\checkmark$ and another letter shows that they comprised at least 400 farms $(\text { fund } i)^{2}$. The relative importance of the Sicilian as compared with the other patrimonies may be estimated by the fact that the letters written by Gregory to the rectors of the Sicilian patrimony exceed in number the total of those written by him to the rectors of all the other patrimonies.

This patrimony was of such size and importance that though, as a rule, the general administration was in the hands of one "rector ${ }^{\mathbf{3}}$," it was found necessary to give him the aid of two assistants, one stationed at Panormus (Palermo) and the other at Syracuse. Under Pelagius II the rector of the whole island had been the deacon Servus-dei, who seems to have been a weak man, unable to check the avarice of his subordinates. Gregory I on his accession in 59r replaced Servus-dei by Peter the sub-deacon ${ }^{4}$, who in turn was replaced in 593 by Cyprian the deacon ${ }^{5}$, who remained till 598. On Cyprian's recall in that year Gregory seems to have thought that the administration of the whole of Sicily was too much for one rector. $\mathrm{He}$ ceased therefore to appoint a rector for the whole island, and divided the administration between the two sub-rectors ${ }^{6}$.

1 Greg. Reg. I. 9, viII. 23, Ix. 28.

2 Ibid. II. 38.

3 For an account of the duties of a rector see pp. 23-32.

4 Greg. Reg. I. I.

5 Ibid. III. 55 .

- Ibid. VIII. 23, Ix. 22. The later history of the Sicilian patrimony does not concern us here, but we may note that together with the patrimonies in Bruttium and Calabria proper it was finally lost to the Roman Church at the beginning of the eighth century, when it was seized by the Emperor Leo the Iconoclast and confiscated to the imperial treasury.

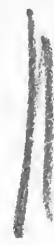


In Italy itself the Church possessed numerous estates.' Starting in the south, we find that there was a patrimony in the territory of Bruttium and Lucania ${ }^{\mathbf{1}}$. This district was famous for its forests, and from it timber was sent to Rome for the repair and building of churches. On one occasion S. Gregory ordered twenty great beams for the repair of the roof of $S$. Peter's ${ }^{2}$, and several letters of his remain in which he requests the various large landed proprietors and the bishops of the neighbouring towns to lend men and oxen to the rector to help in the transport of these beams down to the coast ${ }^{3}$. John the deacon, in his list of the patrimonies in the time of S. Gregory and of the rectors who presided over them during Gregory's pontificate 4 , omits any mention of Bruttium. This seems to have arisen from the fact that in his time the name Calabria had been transferred from the old Calabria (in the heel of Italy) to Bruttium, and he therefore only mentions the Calabrian patrimony, not grasping the fact that in Gregory's time Calabria and Bruttium were distinct ${ }^{5}$. Savinus a sub-deacon is mentioned several times by Gregory ${ }^{6}$ as the rector.

The patrimony in Calabria proper was situated. round the towns of Hydruntum (Otranto) and Calli-

1 Greg. Reg. Ix. 88, 89.

3 Ibid. Ix. 124, 125, I26.

2 Ibid. Ix. I25.

4 Johannes Diac. Vita S. Greg. lib. I.

5 Here and in the rest of this chapter I follow the authority of Grisar, who has thoroughly discussed the position of the various patrimonies at the time of Gregory's pontificate, and the names of the rectors who presided over them (Rundgang durch die Patrimonien des heiligen Stuhles um das Jahr 600. pp. 32I-360 of Zeitschrift für katholische Theologie, 1877).

6 Greg. Reg. IX. I20, I22, X. 2. 
polis (Gallipoli). Zaccaria and Grisar ${ }^{1}$ think that these towns themselves formed part of the patrimony, and base this opinion on two letters of Gregory, one to Occelanus, the tribune of Otranto, and the other to Savinus, bishop of Gallipoli. The letter to Occelanus merely asks him not to overtax the "coloni" of the Roman Church there, but that to Savinus states definitely that the " castrum" or fort of Gallipoli belonged to the Roman Church, as did also the estates round the town ${ }^{2}$. The specific mention of the fort might, however, imply that it alone, and not the whole town, belonged to the Church. The bishop Savinus, and after him Sergius ${ }^{3}$, a "defensor," seem to have been the rectors of this patrimony under Gregory. Calabria and Bruttium were both menaced by the Lombards. In his letter to Occelanus Gregory expresses his fear that if the coloni are overtaxed they will desert to the enemy, and the city will be left undefended ${ }^{4}$.

In the list given by John the deacon mention is made of a patrimony in Apulia, and Romanus, a notary, is named as rector. There is, however, no mention of either Apulia or Romanus in Gregory's letters, and the patrimony seems afterwards to have disappeared in the incursions of Greeks and Lombards.

John also mentions the patrimony of Samnium and gives the name of Benenatus the notary as rector. No

1 Zaccaria, De Patrimonio, p. 105. Grisar, op. cit. p. 336.

2 Greg. Reg. IX. 205.

3 Ibid. Ix. 206. The office of "defensor" is explained below, p. 32 et sqq.

Ibid. IX. 205. 
mention is made of this patrimony by Gregory, though a reference is made by him to Ortona, a town situated there, in a letter ${ }^{1}$ addressed to Scholasticus a defensor, who may have been rector before Benenatus.

An important patrimony existed in Campania. This was administered during the whole of Gregory's pontificate by Anthemius the sub-deacon, except for the years 593-4 when Peter the sub-deacon (previously in Sicily) was rector ${ }^{2}$.

Naples was the natural centre of this patrimony and John the deacon in his list mentions a patrimony of Naples as well as that of Campania. This and the fact that Gregory on one occasion appointed a military officer in the town and generally took great interest in its government have led some to suppose that the whole town belonged to the Roman Church ${ }^{3}$. There does not seem much foundation however for this view; Gregory, when he took the step of appointing the military tribune, took care to explain that he was acting out of consideration for the good of the State and in the name of the Emperor ${ }^{4}$, and his general interest in the welfare of the city seems to have been prompted by the same motives, and by the fact that Naples, being isolated by Lombard territory from the remaining imperial possessions, was beyond the effective control of the exarch at Ravenna. It is probable that the Roman Church possessed some land and houses in Naples, but during Gregory's pontificate at any rate

1 Greg. Reg. Ix. 194.

2 Ibid. III. I.

3 Zaccaria, op. cit. pp. $\operatorname{xI} \mathrm{I}-\mathrm{I} 13$. For arguments against this view see Dudden, Gregory the Great, 1. 297.

4 Greg. Reg. Ir. 34. 
all business in connection with Naples was conducted by the rector of Campania ${ }^{1}$, and Naples seems to have formed an integral part of that patrimony.

This patrimony included some of the small islands lying in the bay of Naples and off the Campanian coast; some of these seem to have produced minerals, and in one of Gregory's letters reference is made to a large quantity of lead in the island of Eumorfiana ${ }^{2}$. These islands formed places of refuge for the clergy and monks flying from the Lombard invasions; and the enforcement of monastic discipline among these refugees gave Gregory considerable difficulty. Campania suffered much from the Lombard invasions, and in some years the revenue arising from the patrimony there was almost entirely expended in the redemption of captives taken by them in their raids ${ }^{3}$.

Mention is made in one of Gregory's letters 4 of a patrimony in the territory of Sabina, and of a certain Urbicus, a defensor, who had been rector there under Pelagius II; but nothing else is known concerning it. There was also a patrimony in the adjoining district of Nursia, and during the early years of Gregory's pontificate this seems to have been administered, together with a patrimony round Carsoleum, by one rector, Optatus the defensor ${ }^{5}$; but according to John the deacon Carsoleum was afterwards detached and put under a rector of its own, Benedict the notary.

1 Greg. Reg. III. I, IX. 82.

2 Ibid. I. $4^{8}$. This island has not been identified with certainty.

3 Ibid. vi. 32.

5 Ibid. XIII. $3^{8}$.

4 Ibid. III. 2 I. 
Another patrimony of some importance was the Patrimonium Appiae. This extended down both sides of the Appian Way and into Latium. Various estates here supplied the basilicas of SS. Peter and Paul with oil and lamps ${ }^{1}$. Felix the sub-deacon is the only rector of whom we have mention ${ }^{2}$. During Gregory's pontificate the whole of Latium was continually raided by, the Lombards. They are mentioned as having occupied the country near Velletri, and as having threatened Tres Tabernae and destroyed Fundi near Terracina $^{3}$. Gregory wrote to the bishop of Terracina 4 to order him to make every citizen take his turn at guarding the walls, and also stated that there were "tree worshippers" near Terracina whom the bishop ought to punish.

A small patrimony-the Patrimonium Tusciaewas situated in Tuscany, but it cannot have been of much importance as the greater part of that district was occupied by the Lombards. Candidus the defensor $^{5}$ and Eugenius ${ }^{6}$ seem to have been the rectors there.

The Roman Church had possessed, for more than a century, a patrimony in Picenum, but though it is mentioned in letters of Pelagius I and Gelasius ${ }^{7}$, no reference to it is made in Gregory's letters or in the list of patrimonies given by John the deacon. It was therefore in all probability occupied by the Lombards during Gregory's pontificate.

1 Greg. Reg. XIV. I4.

3 Ibid. II. I 7, 48, III. I3.

5 Given by John the deacon.

7, Jaffé, Reg. 953 and 633.
2 Ibid.

4 Ibid. virI. I9.

6 Greg. Reg. Ix. 96. 
Patrimonies of the Roman Church were also situated near Ravenna and in Istria ${ }^{1}$. John the deacon mentions a certain Castorius, a chartulary, as rector of the former and a Castorius, a notary, as rector of the latter. The titles chartulary and notary were however interchangeable and probably both patrimonies were united under the same Castorius who is referred to by Gregory as his "apocrisiarius," or nuncio, to the Archbishop of Ravenna ${ }^{2}$. This is extremely likely, as the patrimony in Istria can have been of little value, owing to the constant raids of the Slavs and Avars and to the fact that the Istrian Churches were in schism over the question of the Three Chapters. Castorius was succeeded by John a sub-deacon.

The patrimony in Liguria and round Genoa was probably of little value and had been much reduced by the Lombards. Gregory refers to it as "the little estates" (possessiuncula) of the Roman Church ${ }^{3}$. For a long time no proper rector supervised them but they were looked after by Magnus a priest of the Church of Milan 4. However in the year 600 the Roman notary Pantaleo was sent as rector ${ }^{5}$.

John the deacon mentions another patrimony in the same part of Italy, that of the Cottian Alps, of which Hieronymus the defensor was rector. No mention is made of this however by Gregory, and some

1 For letters referring to Ravenna see Greg. Reg. v. 24, 25 , Ix. 168,178 , and to Istria ibid. 56 .

2 Castorius is referred to in all the letters given in the above note. He is generally called a notary but is termed chartulary in $1 x .151,153$.

3 Greg. Reg. xI. 6.

4 Ibid.

5 Ibid. XI. 14. 
have refused to believe in its existence ${ }^{1}$. Mention is made of this patrimony however by Bede and Paulus Diaconus, who relate that it was restored by Luitprand to the Holy See after having been long occupied by the Lombards.

This completes the number of the patrimonies in Italy with the exception of the estates, houses and gardens possessed by the Church in Rome itself. These formed the patrimonium urbanum and were administered by the seven regionary sub-deacons presided over by one of their number who was called the "primicerius" or chief. The regionary sub-deacons were assisted by regionary defensors and notaries ${ }^{2}$.

We must now turn to the patrimonies possessed by the Roman Church outside Italy. In the south of Gaul there were situated a few estates belonging to the Church, and these were at the time of S. Gregory the only estates which it possessed outside the boundaries of the Empire. These estates, though not of much value in themselves, were the object of considerable attention from Gregory, as they offered a means of getting into closer communication with the Frankish kingdoms, and thus of spreading the influence of Rome in the west. They were divided into two parts, centring respectively round Arles and Marseilles, and were, as a rule, administered by local officials or bishops. In the time of Pelagius I Placidus ${ }^{3}$ the father of Sapaudus bishop of Arles had administered them. Under Pelagius II Licerius bishop of

1 Zaccaria, De Patrimonio, p. I20.

2 Greg. Reg. viII. I6. See also II. Io, III. I7.

3 Jaffé, Reg. 943, 947. 
Arles was rector ${ }^{1}$, and he was succeeded by a certain Dynamius $^{2}$, a patricius. Dynamius however, who was a count under one of the Frankish kings, incurred royal displeasure ${ }^{3}$ and on his fall Gregory seized the opportunity of bringing this patrimony into line with the others and sent the Roman priest Candidus to be rector. It may be noticed that Candidus was the only rector under Gregory who was a priest ${ }^{5}$, and that he received numerous letters of recommendation ${ }^{6}$ to all the chief men of Gaul. It is plain that Gregory intended to employ him for higher purposes than those of mere administration, and he made endeavours to induce the Gallic bishops to hold councils for the reform of the Gallic Church at which Candidus was to be present as papal representative. A curious fact. may be noted in passing about the Gallic patrimony. The money current in Gaul was of a different weight from that current in Italy, and so Gregory instructed ? Candidus not to remit the rents from the patrimony to Rome in money but to expend them on the poor of the Gallic patrimony itself or in the purchase of English slaves who were to be sent to Rome to be

1 Greg. Reg. VI. 5I.

3 Ibid. vir. 33. See Ewald's note on III. 33.

4 Ibid. vi. 5, I0, 5 I.

5 The maiority of the rectors were defensors or sub-deacons.

6 Greg. Reg. vi. 6 (to King Childebert), 49 (to Kings Theuderich and Theudebert), 50 (to Pelagius of Tours and Serenus of Marseilles), 5I (to Vergilius of Arles), 52 (to Desiderius of Vienne and Syagrius of Autun), 53 (to Protasius of Aix), 56 (to Arigius, patrician), 57 (to Queen Brunhild); see also XI. 43 and 44 .

7 Ibid. vi. Io. The Gallic solidi were probably lighter than the Roman by $\frac{1}{8}$, i.e. they contained about 21 siliquae, and 84 went to the libra. 
educated there in preparation for Augustine's mission to England.

The Roman Church also possessed estates in Corsica $^{1}$ and Sardinia ${ }^{2}$. These islands seem to have been especially backward and to have suffered more than was usual from the rapacity of the imperial officials.

There were considerable numbers of pagans still left among the wild tribes of the interior of these islands-in Corsica some of the coloni on the patrimony of the Roman Church were still pagan ${ }^{3}$-and Gregory made great efforts for their conversion, sending a special mission for this purpose and calling in the help of the officials 4 . He made efforts also to protect the unfortunate provincials from the tyranny and oppression of the imperial officials there, complaining both to the Empress Constantia ${ }^{5}$, and to the Exarch of Africa ${ }^{6}$ in whose jurisdiction the islands. were included, while on one occasion he instructed Vitalis the rector in Sardinia to go himself if necessary to Constantinople to lay the grievances of the inhabitants before the Emperor ${ }^{7}$. The Lombards, though not as a rule a seafaring people, seem to have made some attempts on Sardinia, and Gregory on one occasion wrote to the Archbishop of Cagliari, the metropolitan of the island, warning him to insist on the citizens of every city performing their duties of watch and ward ${ }^{8}$, and refused to allow a new monastery to be founded near the coast ${ }^{9}$. These Lombard raids

1 Greg. Reg. I. 5 O.

3 Ibid. vill. 1 .

5 Ibid. v. 38 .

7 Ibid. xIv. 2.
2 Ibid. III. 36.

4 Ibid. IV. 23, 26, XI. I2.

6 Ibid. XI. 7 .

8 Ibid. IX. I $\mathbf{r}$.
Ibid. 1. 50. 
seem to have had some success, as Gregory afterwards reproached both the Archbishop and the Exarch with their neglect of their duties. The patrimony in both islands was first administered by Symmachus the defensor ${ }^{1}$, but they were then separated, and Boniface the deacon was appointed to Corsica ${ }^{2}$, while Sardinia was assigned to Sabinus ${ }^{3}$, and after him to Vitalis the defensor ${ }^{4}$.

The Roman Church possessed also a small patrimony in Africa. This is called by John the deacon "that of Germanicia," and was probably situated near the town of that name in the region of Hippo. These estates were probably given to the Roman Church during the fourth centuryfor at the beginning of the fifth, before the Vandal invasion, and were restored to the Church on the reconquest of Africa by Belisarius in the reign of Justinian. Owing to the constant wars with the native tribes and with the Donatists, these lands can have been of little value. The Exarch of Africa in Gregory's time was a certain Gennadius who was on good terms with the Pope and recolonised the depopulated lands of the Church with barbarians who had commended themselves to the protection of the Empire. Gregory warmly thanked Gennadius for his care for the property of the Church, and recommended to him the deacon Hilary, whom he sent as rector to Africa ${ }^{5}$.

Lastly, the Roman Church possessed two small

1 Greg. Reg. I. 50.

3 Ibid. III. 36.

5 Ibid. I. 73. In Reg. I. 74 Gregory commended Hilary also to Gaudiosus, the magister militum.

S. P. 
patrimonies in the Balkan peninsula, one in Dalmatia and the other in Illyriav The Dalmatian patrimony had existed in the time of Gelasius, who referred to it as reculam beati Petri apostoli inter Dalmatias constitutam $^{1}$. Gregory terms it "a tiny little patrimony" (exiguum patrimoniolum) ${ }^{2}$. A local bishop named Malchus was rector there at the beginning of Gregory's pontificate, but his conduct was unsatisfactory, and he was summoned to Rome to explain his accounts, as he was suspected of embezzlement. While there he died $^{3}$, and Gregory appointed as the new rector the defensor Antoninus ${ }^{4}$, thus following the same policy as in Gaul of replacing local officials or ecclesiastics by Roman clerics.

There is no direct mention in Gregory's letters of the patrimony in Illyria ${ }^{5}$, but John the deacon gives the name of the rector there as John the notary. This was probably the same as that referred to by Vigilius as the patrimony of Praevalitana, since that province was in the diocese of Illyricum. Both this patrimony and the one in Dalmatia suffered severely from the invasions of the Avars and Slavs, and there are frequent references in Gregory's letters to their depredations ${ }^{6}$.

1 Jaffé, Reg. 686. Migne, 59, p. I54. Recula denotes a small field.

${ }_{2}$ Greg. Reg. II. 23. Grisar takes this letter to apply to the patrimony in Illyria, but it seems more likely that it refers to Dalmatia, as the preceding letter is to Antoninus, who was rector there. See also Ewald's note to 1. 43 .

3. Greg. Reg. v. 6.

4 Ibid. II. 22, III. 9, 22.

- See note 2 above with reference to II. 23.

6 Greg. Reg. I. 43, II. 37, X. I5. 
The question whether the Roman Church ever possessed any estates in Asia or the East generally has been much discussed, and one writer, relying on certain lists, quotéd by Baronius, of farms stated to have been given by Constantine to the Roman Church, concludes that the Roman Church did in fact at one period possess such estates but that in the time of Justinian or subsequently they were exchanged for lands in the West ${ }^{1}$. It may be noted in this connection that a law of Justinian's, enacting that a prescriptive title to church lands should not be acquired to the detriment of the Roman Church till after a period of roo years, expressly states that this provision should apply to any lands which the Roman Church possessed or might thereafter possess in the East ${ }^{2}$. This however may refer to the patrimonies in Dalmatia and Illyria which were included in the Eastern prefecture of Illyricum. No other reference exists to the possession of Roman patrimonies in the East and it may be assumed that no such patrimony existed in the time of Gregory.

This short survey of the papal patrimonies shows that they were of considerable extent and that they must have been of great value. Various attempts have been made to estimate their extent and the annual rental, but these are almost pure guesses and of no real importance ${ }^{3}$. There is a statement of Theophanes,

1 Zaccaria, op. cit. Baronius' lists are open to doubt.

2 Novel. IX.

3 According to Grisar (op. cit. p. $35^{8}$ ), Bianchini put the total revenue from the various patrimonies at 200,000 solidi in cash, plus rents in kind worth another 500,000 solidi. This would mean a total revenue of $t 420,000$ approximately. 
however, as to the revenue from two of the patrimonies, which is useful, as showing how extremely valuable the patrimony must have been, and as giving some slight idea as to the largeness of the total revenue.

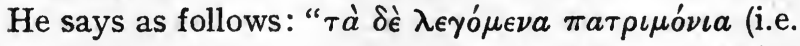

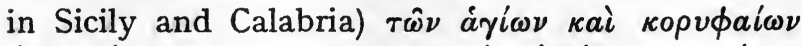

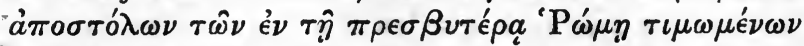

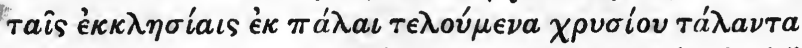

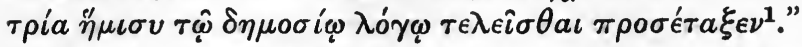
This sum of $3 \frac{1}{2}$ talents equals $350 \mathrm{lbs}$. of gold or 25,200 solidi, which reckoning the solidus as being in intrinsic value equal to rather over I2s. ${ }^{2}$ makes the respectable yearly income of $£$ I5, I20 without taking into account the difference in the value of money. It must be remembered however that Sicily was probably by far the richest patrimony.

Scharpff estimated the total area of the patrimony as equal to that of the Duchy of Nassau, an area of 1830 square miles.

1 Theophanes, Chronographia, ed. Classen, p. 631.

2 Grisar (op.cit. p. 330) says that the solidus was intrinsically equal to $15 \frac{1}{2}$ francs, and Hartmann makes it equal slightly more than 12 marks. 


\section{CHAPTER II}

\section{THE GOVERNMENT OF THE PATRIMONY}

THE administration of the large and valuable es-

tates which formed the patrimony of the Roman Church necessitated an extensive organisation and the existence of numerous officials. This system of administration, though necessarily rather elaborate, was based on simple and sensible principles and seems to have been very efficient, forming a striking contrast to the needlessly complex and inefficient imperial administration with its absurd division of powers between various over-lapping sets of officials.

But, though in one way a contrast to the imperial administration, the papal administration of the Patrimony was yet largely influenced by its example. The Pope in his absolute power may be compared with the Emperor, the rectors with the provincial governors, while the Church, like the State, possessed its defensors, notaries, and courts of justice.

In this essay the administration of the Patrimony is described as it was at the end of the sixth century. The letters of Gelasius, however, show an organisation in the fifth century similar in all essentials, and the system seems to have altered but little in the intervening period.

At the head of the whole administration stood the Pope, and under him at the head of each separate portion of the Patrimony was placed a rector in whom 
the local administration centred. These rectors were appointed by the Pope, though the consent of the Roman clergy was nominally necessary, this being probably a survival from the time when the monarchical character of the episcopate had not been finally established. At one time it seems to have been quite usual to appoint local laymen or bishops to be rectors of the various patrimonies and this seems to have been specially the case in the outlying districts; thus Archbishop Licerius ${ }^{1}$ of Arles and after him the patrician Dynamius ${ }^{2}$ were rectors in Gaul; a local bishop Malchus ${ }^{3}$ was rector in Dalmatia at Gregory's accession; while the exarch Gennadius ${ }^{4}$ himself seems to have supervised the African patrimony; Magnus ${ }^{5}$ a priest of the Milanese Church was for some time rector of Liguria; and under Pelagius I Julian, bishop of Cingulum, was rector of Picenum ${ }^{6}$. Gregory, however, set his face against this custom and gradually replaced these lay and alien rectors by Roman clerics; this soon became the established custom of the Roman Church, and Pope Conon (686-687) is bitterly reproached by the writer of Liber Pontificalis for having appointed a Syracusan deacon to be rector of Syracuse?

1 See Greg. Reg. VI. 5 I (to Vergilius of Arles). Quia igitur patrimoniolum ipsum per annos plurimos predecessor vester tenuit.

3 Ibid. II. 22, III. 22.

5 Ibid. xI. 6. 2 Ibid. III. 33.

- Ibid. I. 73 .

6 Jaffé, Reg. 953, 956.

7 Ultra consuetudinem absque consensu cleri ex immissione malorum hominum in antipathia ecclesiasticorum Constantium diaconum ecclesiae Syracusanae rectorem in patrimonio Siciliae constituit; hominem perperum et tergiversatum. Lib. Pont. ed. Duchesne, vol. I. p. 369. 
Sub-deacons were frequently appointed as rectors ${ }^{1}$, but the greater number were men holding the office of defensor, or even the inferior office of notary or chartulary. It should be noticed that the defensorship and notariate were not among the minor orders of the Church, but were merely official positions; the spiritual status of the defensors and notaries being as a rule that of acolytes. Till the time of Pelagius II not only acolytes, but sub-deacons also, were allowed to marry; Pelagius forbade for the future the marriage of sub-deacons and this decree was enforced by Gregory. Defensors and notaries, however, being only acolytes, continued to marry and there are several references in Gregory's correspondence to the families of rectors ${ }^{2}$ of patrimonies.

On receiving from the Pope an intimation as to his appointment the new rector took a solemn oath before the relics of S. Peter, always to seek the good of the Church and to defend the poor ${ }^{3}$. He then received the diploma of his appointment, which, after reciting that he had been faithful and industrious, stated that the Pope had decided to commit the care of a patrimony to him and warned him against negligence and fraud 4 .

The "breve," or estate book of his patrimony, which contained the list of all the properties comprised in

1 A deacon was sometimes appointed to an important patrimony, e.g. Cyprian in Sicily, and there is one case of a priest, Candidus, being sent to Gaul.

2 E.g. Greg. Reg. III. 21, IX. 93.

3 Ibid. xIII. 37. Experientia tua, quod vel quale apud sacratissimum corpus beati Petri apostoli iusiurandum praebuerit, memor est. Cf. Lib. Diurn. 74, the oath taken by a bishop.

${ }_{4}^{4}$ Greg. Ix. 29. The formula in Lib. Diurn. 52 is almost exactly similar except for the opening sentence. 
the patrimony, was then given to him ${ }^{1}$. When any estate in the patrimony was for any reason alienated or made over to a monastery or another church, it was at once struck out of the breve" ${ }^{2}$. A copy of the oath which he had taken, called a "cautio," was then filed in the papal "scrinium" or registry ${ }^{3}$. The rector was then ready to depart to his patrimony and take up his office; but before he went he received from the Pope a "capitulare" or list of detailed instructions as to his conduct in the patrimony and the way in which he was to act in the most important matters. This was not a formal document but varied with the circumstances of the case. In a letter to Peter the subdeacon Gregory warns him to be always mindful of the instructions given to him in his capitulare ${ }^{4}$ : and we possess a capitulare given to a certain John the defensor, who however was not a rector but was sent on a special mission to Spain to try the case of certain bishops there ${ }^{5}$. Before the departure of the rector a letter had been sent to the coloni or serfs ${ }^{6}$, and the

1 Jaffé, Reg. 950. Pelagius Vito defensori; ut secundum morem et emittas in scrinio cautionem et brevem eiusdem patrimonii possis accipere.

${ }^{2}$ Greg. Reg. xIV. I 4. Idcirco experientiae tuae praecipimus, ut suprascriptam Massam Aquas Salvias cum praenominatis omnibus fundis suis nec non hortus atque terrulas quae superius continentur de brevibus suis delere debeat ac auferre et cuncta ad nomen praedictae ecclesiae beati Pauli apostoli tradere.

3 Jaffé, Reg. 950.

4 Greg. Reg. I. 39 a. Pergenti tibi ad Siciliam capitulare quod dedi adsidue relegendum est.

5 Ibid. XIII. 47. See also for mention of a capitulare IX. I3I and XI. 14. Sollicitum esse necesse est et ita omnia secundum capitularem subter adnexum requirere utiliterque disponere.

- Ibid. Ix. 20 and Lib. Diurn. 53. This latter formula is almost identical with Gregory's letter except for the following 
conductors $^{1}$, or farmers, of the patrimony, informing them of the new appointment and exhorting the coloni to obey the rector and assist him in every way, and also warning them that he had been instructed to punish severely any disorder or attempts on their part to remove from the patrimony. The rector also took with him various letters of recommendation to the large landowners ${ }^{2}$ and imperial officials ${ }^{3}$ in the patrimony and to the local bishops ${ }^{4}$, and it seems that it was usual for the rector to give small gifts to the local officials.

When the new rector arrived he found duties of every kind awaiting him; he had to consider questions as various as the price of corn, the merits of pastoral as opposed to arable farming, and the character of the candidates for a vacant bishopric; but his duties may be roughly divided into those which concerned the everyday business organisation of the patrimony and those which related to his powers of ecclesiastical supervision.

Perhaps the most important side of his temporal duties was that which related to the collection of the

sentence; iubemus enim ut eius praesentia utilitatibus et culture agrorum mandatis parere properetis. Gregory's letter contains no reference to agriculture.

1 For a letter to the conductors see Greg. Reg. v. 3I.

${ }^{2}$ Greg. Reg. IX. 33 (commending Romanus to Peter, a "gloriosus"), and v. 56 (commending Candidus to Arigius, a "patricius").

3 Ibid. I. 2 (commending Peter the sub-deacon to Justin praetor of Sicily), and IX. 3 I (commending Romanus to Cyridanus).

4 Ibid. VI. 50, 5I, 52, 53. See also the formulae given for each of these cases in Lib. Diurn. 54 Praeceptum commendaticium eunte rectore in patrimonio ad iudicem provinciae. 55 Item ad patricium. 56 Item de episcopos (sic). 
rents and revenues from his patrimony. The questions relating to these subjects will be considered in detail in a later chapter but it may be as well to give a short account of the rector's duties in regard to them here. The revenues, the major part of which consisted of the payments in the nature of rent made by the coloni or actual cultivators, were collected by the rector's agents ${ }^{1}$ from the farmers (conductors) to whom they were paid in the first instance, and the rents paid by the conductors for their farms were collected at the same time ${ }^{2}$.

All these payments had to be carefully entered by the rector in his accounts or "rationes," as well as the expenses which he incurred in the ordinary course of the administration, such as the payment of salaries or the payments which he made by special papal command $^{3}$. These account books were sent to Rome at the end of each year of the indiction and it seems that it was usual for the rector himself to bring them to Rome if his patrimony were one not very distant from the city. The actual money in hand was also sent at the same time ${ }^{4}$. The money paid in was then credited

1 This is plain from the letter addressed by Gregory to John the bishop of Syracuse, who was temporarily acting as rector there, in which he rebukes him for insisting that the conductors should come to one place to make their payments. Rents, Gregory says, may be paid anywhere.

2 Occasionally conductors seem to have paid directly into the papal treasury. See the receipts given by Gelasius to Vincomalus. Jaffé, Reg. 667.

${ }^{3}$ Greg. Reg. I. I8, 23.

4 See ibid. I. 37 (to Anthemius rector of Campania). Cum summa vero pensionis sub festinatione et iam ad paschalem diem Domino auxiliante occurrito. See also 11. 38 , IX. 84 . 
to the rector in the accounts of the papal treasury after his accounts had been carefully examined by the papal officials, and finally if everything were satisfactory a receipt or "securitas" was given to him 1 .

But the rector had not only to collect the revenues of his patrimony and send them to Rome, he had also to supply the Roman court with various articles of produce when required to so so. Gregory in one famous letter rebuked Peter the sub-deacon for having sent him from Sicily only one wretched horse and five asses $^{2}$. In another letter he mentions that he has requested Anthemius, rector of Campania, to send him twenty-four "sellas plectiles" (saddles of some kind) ${ }^{3}$. Savinus, rector of Bruttium, was charged with supplying the timber for the repair of S. Peter's ; and the timber sent to Eulogius, patriarch of Alexandria, was probably also supplied by him. In another letter Gregory gives directions as to the disposal of a quantity of lead, the product of the island of Eumorfiana in the patrimony of Campania 5 .

The rector of Sicily, in particular, was charged with the care of a large portion of the corn supply of Rome. Not only were large consignments of corn regularly

1 See letter of Pelagius I to Maurus, bishop of Praeneste. Jaffé, Reg. 95I. Ideoque supplicante dilectione tua ex omnibus suprascriptis praeteritis sex indictionibus Fraternitatem tuam hac securitate credidimus muniendam ut nulla caritati tuae in posterum a quolibet calumnia moveatur. Migne, 69, p. 4I 7 .

2 Greg. Reg. II. 38. Praeterea unum nobis caballum niserum et quinque bonos asinos transmisisti. Caballum illum sedere non possum, quia miser est, illos autem bonos sedere non possum, quia asini sunt.
3 Ibid. Ix. I7.
5 Ibid. I. 48.
4 Ibid. IX. 124, 125, 126, 127. 
purchased by the Church from the revenue of the patrimony there ${ }^{1}$, but the rector was occasionally charged with the purchase of additional amounts of grain to be sent to the city, and he had to see to the collection and shipment of this ${ }^{2}$.

The rector was not only a tax collector; he was also a steward and estate agent. It was his duty to see that the ploughs and agricultural implements of the Church were kept in repair ${ }^{3}$, that useless flocks and herds were not kept ${ }^{4}$, that the coloni and slaves of the Church did not leave the church lands ${ }^{5}$, that leases of church lands were granted only to desirable tenants ${ }^{6}$. He had also to supervise the relations of the conductors to the coloni and see that the latter were not forced to make extortionate payments to the former and were not oppressed by them?. Over the slaves and coloni of the church he exercised the powers which the Church possessed as their "dominus." It must be remembered that the status of a colonus was semiservile and that his lord, or dominus, exercised over him all the powers of criminal jurisdiction, while over a slave the power of the dominus was absolute, and

1 See Greg. Reg. I. 42, as to the corn which was regularly bought by the church from the coloni through the conductors.

2 Ibid. r. 70. Quinquaginta vero auri libris nova frumenta ab extraneis compara et in Sicilia in locis, in quibus non pereant, repone, ut mense Februario illic naves quantas possumus dirigamus et eadem ad nos frumenta deferantur.

3 Ibid. II. 38. "Aeramenta" prob. means ploughs.

4 Ibid.

5 Ibid. IX. I28.

6 Ibid. Ir. Io, see also Lib. Diurn. 34. Praeceptum auctoritatis de faciendis chartulis.

7 The relations of the conductors to the coloni and the extortions practised by the former on the latter will be explained in the following chapter. 
these powers were exercised over the "familia" of the Church by the rector as papal representative 1 .

Among the most important of the rector's duties was the care and protection of the poor; he was, if one may say so, the chief poor law officer of his patrimony. Gregory ${ }^{2}$ is never tired of insisting on the importance of this side of the rector's office and on the duties of the Church to the poor. Not only was the rector the official through whom the numerous acts of papal bounty ${ }^{3}$ were exercised; he was charged also with the supervision of all the "xenodochia ${ }^{4}$," or church rest houses and infirmaries, in his district, and was instructed to see that the bishops of his district carried out their duties with regard to the quarter of their revenue which by canon law was allotted to the poor ${ }^{5}$ and with regard to the "matricularii ${ }^{6}$," or persons in receipt of relief, entered on the books of their church. $\mathrm{He}$ was frequently instructed by the Pope in individual cases of oppression to defend and aid the oppressed party and where necessary to give them the ecclesiastical "tuitio" or protection?.

1 Greg. Reg. I. 42.

2 E.g. ibid. I. 37. Discedenti tibi mandavimus et postmodum praeceptis discurrentibus iniunxisse me memini, ut curam pauperum gereres et, si quos illic egere cognosceres, scriptis recurrentibus indicares. Et vix de paucis haec facere curasti.

3 The system of poor relief will be explained in greater detail in Chap. vi.

4 Greg. Reg. I. 42, Iv. 24, IX. 35. He undertook this duty as representing the metropolitical jurisdiction of the Pope.

"Ibid. XI. 42.

"The ecclesiastical "tuitio" apparently meant that the church claimed an interest in the persons so protected and that a defensor would be instructed to defend them against unjust aggression. Ibid. IX. 193. 
The exercise of the important papal powers of jurisdiction in districts situated near a patrimony was also as a rule delegated by the Pope to the rectors. By ecclesiastical as well as civil law all matters of purely ecclesiastical nature and offences against ecclesiastical discipline were to be tried in ecclesiastical courts, and in such cases the Pope was the final court of appeal ${ }^{1}$. Cases of any kind between two bishops and all actions brought by a clerk against his bishop were by imperial law to be tried in the first place before the metropolitan of the province with a right of appeal to the Patriarch. All such cases in Southern Italy and Sicily came therefore in the first instance before the papal court, and from the rest of Italy and the West might be brought before it on appeal from the courts of the metropolitans. An immense mass of litigation came therefore before the papal courts and only the most important cases were reserved for the Pope's personal hearing. In the ordinary course of events such cases would be tried before the papal vicar ${ }^{2}$, and in cases where no vicar was specially appointed his place seems to have been usually taken by the rector of the nearest patrimony or by a defensor specially sent for the purpose $^{3}$. This legal and judicial work must have added an immense burden to the already heavy duties of the

1 See Just. Novel. cxxirr.

2 Outside Italy one of the leading metropolitans of the country or province was generally appointed papal vicar. Thus in Gaul the vicariate was exercised by the Archbishop of Arles.

3 In Gregory's time there seems to have been no resident vicar in Spain and the defensor John was sent as special envoy to try the case of certain bishops there (Greg. Reg. XIII. 47-50); in later times the vicariate was always given to the Archbishop of Toledo. 
rectors and it seems indeed to have bid fair to become the most important of their duties; the larger number of Gregory's letters to the rectors of the various patrimonies are concerned with business of this description.

The rector was also frequently entrusted with the duties of an arbitrator. He had to do his best to prevent litigation, and he was often ordered to urge the parties to compromise or to bring their suits to a speedy hearing ${ }^{1}$.

In Southern Italy and Sicily, which were under the metropolitical jurisdiction of the Pope, the rectors generally acted as papal delegates and performed the duties which later were entrusted to legates. Peter the sub-deacon was at first appointed papal vicar in Sicily ${ }^{2}$, though it is true that this office was later given to bishop Maximian of Syracuse ${ }^{3}$. These ecclesiastical powers, though they do not strictly concern the Patrimony, are yet worthy of mention. The rectors had to warn negligent bishops to perform the duties of their office ${ }^{4}$, to prohibit bishops from acts of oppression ${ }^{5}$, to punish disobedient or immoral monks and clerics ${ }^{6}$, and to enquire into the characters of candidates for vacant bishoprics or abbacies ${ }^{7}$. In patrimonies outside the papal metropolitanate they acted as the papal "apocrisiarii" or ambassadors to the metropolitans in whose dioceses they were situated ${ }^{8}$.

Possessed of such enormous powers and beset with

1 Greg. Reg. vir. 36.

2 Ibid. I. I.

3 Ibid. II. 8.

4 Ibid. vi. 23 , XI. 53, XIIr. 29.

5 Ibid. II. 22, III. 8.

- Ibid. IV. 6, X. 2, xrv. I7.

7 Ibid. III. 22, 23, 39, X. 7 .

8 See Hartmann's note to Greg. Reg. v. 24. In Gaul the rector Candidus acted as papal ambassador at the royal court. 
[CH.

such multifarious duties it is no wonder that the rectors sometimes abused their positions. Gregory was obliged to upbraid even Peter the sub-deacon with slackness and with acting at times through fear or favour ${ }^{1}$. The case of bishop Malchus, guilty of embezzlement, has already been mentioned, and under Pelagius $I$ there is a case of a rector removed for misappropriation ${ }^{2}$. But on the whole they seem to have filled their difficult posts with skill and discretion.

It is obvious that a considerable staff of officials must have been necessary to assist the rector in the execution of his arduous duties, and we find, as a fact, that in the larger patrimonies he had under his control numerous officials of various ranks. The most important of these were the defensors.

Mention has already been made of the defensors and of the fact that the rectors were frequently appointed from their number. The ecclesiastical defensorship was modelled on the office of the "defensor civitatis," or the municipal defensorship. This was an office created by an ordinance of Valentinian and Valens in the year 364 when officers called defensors were ordered to be appointed in every city for the protection of the plebs ${ }^{3}$; their duty was to defend the poorer citizens in the courts and where possible to prevent oppression on the part of the imperial officials. They are frequently referred to in the letters of Cassio-

1 Greg. Reg. Ir. 38. Praeterea cognovi, quia quasdam res vel plures fundorum alieni iuris esse cognoscis, sed pro quorundam obtestatione vel metu dominis suis restituere formides. Qui si veraciter christianus esses, plus Dei iudicium quam voces hominum timeres.

2 Jaffé, Reg. 1025.

$s$ Cod. Theo. I. rr. I. 
dorus $^{1}$ and were apparently in the West still persons of importance at the end of the fifth century. This last attempt to awaken the spirit of municipal independence in the Empire was, however, doomed to failure and by Gregory's time the office had become almost extinct; there are but three references in his letters to the "defensores civitatum 2."

It is impossible to date the origin of the ecclesias tical defensorship accurately; the first mention of an ecclesiastical defensor does not occur till 483 in a letter of Felix III ${ }^{3}$ but they are frequently mentioned a few . years later in the letters of Gelasius and Pelagius I4. In all probability the office was a creation of the late fourth or early fifth century. The defensorship was not an office peculiar to the Roman Church and defensors seem to have been appointed in all the large cities in both the East and the West. Defensors of the Milanese Church are mentioned by Cassiodorus ${ }^{5}$, and Gregory makes mention in his letters of defensors of the Churches of Ravenna, Milan and Salona ${ }^{6}$.

The Roman defensors were appointed by the Pope, and received a diploma conferring the office on them ${ }^{7}$.

1 E.g. Cass. Var. vir. Ir. Formula of appointment of a municipal defensor. See also Greg. Dialogues, lib. II. c. 20, where it is related that a monk, the son of a defensor civitatis, thought it an indignity that one of his standing should have to wait on the Abbot Benedict.

${ }^{2}$ Greg. Reg. III. 39, IX. I55, I98 (IX. I55 is ambiguous, and may possibly refer to an ecclesiastical defensor).

3 Jaffé, Reg. 593.

4 Ibid. 678, 949, 950, 964, roo4. Migne, 59, p 99; 69, pp. $4 \mathrm{I} 5,4 \mathrm{I} 8$.

5 Cass. Var. II. $30 . \quad$ Greg. Reg. virl. 3.

7 Ibid.v. 26. Ecclesiasticae utilitatis intuitu id nostro sedit arbitrio, ut, si nulli condicioni vel corpori teneris obnoxius nec 
In the large patrimonies they acted as the assistants of the rector. Among their duties were the stewardship of the coloni, and the conduct, before the lay judges, of cases in which poor persons or those under the ecclesiastical protection were concerned. In cases brought before the bishops the defensors often acted as assessors ${ }^{1}$, and in the absence of a rector the defensor, as representing the Pope, acted as judge in suits brought against a bishop ${ }^{2}$. Their chief duty, however, was the administration of the poor relief. The execution of acts of papal bounty was usually entrusted to them by the rector, and they had the general management of the corn supply. That this was one of their earliest duties is shown by a letter quoted by Cassiodorus $^{3}$, in which, after stating that the defensors of the Church of Milan wished to buy as cheaply as possible what they needed for the relief of the poor, King Theodoric allows one merchant to buy for them in the market free from the duty on sales and from the payment to the Crown of a certain tax. It is probable that some of the early imperial privileges granted to clerks engaged in trade were really intended to help the defensors in their charitable work. The defensors were also frequently employed personally by the Pope on various missions; thus we find one defensor sent to

fuisti clericus alterius civitatis aut in nullo tibi canonum obviant statuta, officium ecclesiae defensoris accipias et quic quid pro pauperum commodis tibi a nobis iniunctum fuerit, incorrupte et naviter exequaris. The disabilities of status were those attaching to soldiers, curials, members of artisan guilds, coloni or slaves. See also IX. 97.

\footnotetext{
1 Greg. Reg. IX. 68.

${ }^{8}$ Cass. Var. II. 30.

2 Ibid. XI. 24, XIII. 47, 49.
} 
Spain, and another employed by the Pope to collect the church plate which had been carried into Sicily by priests flying from the Lombards ${ }^{1}$.

It will be seen from what has been said that much of the routine work of the patrimonies was carried on by the defensors, and it is likely that in the larger patrimonies the rector concerned himself chiefly with his ecclesias tical and judicial duties and allowed the administration to be carried on largely by the defensors. This was an undesirable tendency, as it gave the defensors many opportunities for oppression. An example of its dangers was afforded by the state of the Sicilian patrimony during the pontificate of Pelagius II, when innumerable acts of oppression and injustice were committed by the defensor Antoninus, of which the rector Servus dei, an excellent but weak man, seems to have been ignorant, and which did not come to light till after Antoninus's death ${ }^{2}$. Gregory seems to have recognised the danger of allowing the defensors too much control in the administration, and consistently pursued the policy of urging the rectors themselves to enquire into and remedy abuses. The defensor's office was one of great power and profit and an object of desire, and as a result not only did some unworthy persons succeed in obtaining it, but in Sicily at any rate many persons, without any shadow of justification, went about claiming to be defensors and terrorising the bishops and conductors. Gregory had to write to the bishops of Sicily to warn them against

1 Greg. Reg. XIII. 47-50, IX. I9.

2 Ibid. x. 39 a. We learn from I. 42 that Antoninus was dead. 
these bogus defensors and to instruct them to make no payment to anyone unless he could produce his diploma of appointment by the Pope or rector ${ }^{1}$. In another letter Gregory instructed Romanus the rector of Syracuse to exile a certain Marcian, a pseudo defensor, and to punish certain of the minor officials of his own staff who had claimed to be defensors ${ }^{2}$.

Beside the defensors the rectors were assisted by another class of officials known as notaries or chartularies. These terms seem to have been used indis-

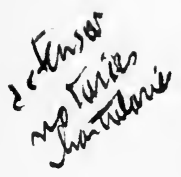
criminately to denote the same officials ${ }^{3}$. These notaries were clerks in the modern sense of the term; they seem to have been.occupied chiefly in the financial side of the administration of the patrimony, to have kept the rector's accounts and drawn up leases and other documents. In Rome they acted as secretaries to the Pope and conducted the papal correspondence ${ }^{4}$. They were not however confined to this class of duties; some of the rectors of patrimonies were chosen from their ranks, and like the defensors they were oftensent by the Pope on special missions of importance ${ }^{5}$.

1 Greg. Reg. I. 68.

2 Ibid. Ix. 22.

3 Thus Adrian, the last rector of Syracuse under Gregory, is called a notary in Greg. Reg. IX. IIO, XI. 30, 33, xIV. I 7, but is referred to as a chartulary in XIII. 22. Castorius is described as a notary in V. 24 and as a chartulary in IX. $15 \mathrm{I}$.

4 The diploma of appointment given to a defensor contained the phrase "hanc epistolam notario ecclesiae nostrae scribendam dictavimus." See Greg. Reg. v. 26.

- Peter (of Bruttium), Benedict (of Carseolum), Castorius (of Ravenna), Boniface (of Corsica), Pantaleo (of Liguria), Hilary (of Africa), and Eugenius (of Tuscany) were all notaries or chartularies acting as rectors during Gregory's pontificate. Pantaleo a notary (not the rector of Liguria) was employed by Gregory on several missions of importance in Sicily. 
Lastly, in the lowest rank of the rector's officials were the "actionaries" of the Church, who acted as inferior clerks, bailiffs, and executive officers. As bailiffs they seem to have been keenly on the watch to prevent any encroachments on the church lands, but they did not always rest content with this and were in the habit of seizing without much ceremony any property to which they considered the Church had a claim, and numerous complaints of their highhanded actions are preserved in Gregory's letters ${ }^{1}$. Against such methods of procedure Gregory set his face sternly, and carefully instructed the rectors that claims by the Church to other lands were to be prosecuted legally and not by force ${ }^{2}$. We may note here that the salaries of the church officials do not seem to have been always paid very regularly and this fact may explain much of the oppression which they practised. Gregory was careful to see that all the officials in the service of the patrimonies obtained their salaries. In one letter he told Peter the sub-deacon to see that his defensor Fautinus (who had been legacy-hunting) was properly paid so that he might be able to live on his salary ${ }^{3}$, and in another letter he instructed Peter to see that the substitutes whom he left behind in

1 Greg. Reg. I. 9, 7 I.

2 Ibid. I. 39 a. Gregory forbade the affixing of "tituli" or notices of ownership on lands to which the title was disputed. This custom was borrowed from the practice of the imperial treasury. Where lands were seized in default of payment of taxes, a titulus was affixed declaring them to be the property of the fiscus, and it would then be treason to take them.

3 Ibid. I. 42. 
Sicily and the overseer of a certain xenodochium received sufficient pay.

The actionaries were as a rule laymen. Gregory instructs Peter, the rector of Sicily, to select any laymen he may think suitable and have them tonsured; they are then to receive letters of appointment allowing them to act as actionaries under the rector. The giving of the tonsure does not seem to mean that any orders were conferred, but was merely a sign that they were church officers and formed part of the rector's "officium" or staff ${ }^{1}$.

The whole of the organisation above described was not peculiar to the Roman Church but was shared by it with all the great Churches of Italy and the East. The Church of Constantinople, especially, possessed a patrimony rivalling the Roman in extent and wealth, and as the organisation of this is described in some detail in the laws of Justinian ${ }^{2}$ and as these throw some. light on the minutiae of the organisation of the Roman patrimony it may be worth while to give a short account of it. The rents in each patrimony were, as in the Roman patrimonies, collected by the farmers (conductores) and each patrimony seems to have been presided over by an "administrator" corresponding to the rector. At Constantinople the business of the patrimony in each diocese of the patriarchate was supervised by an "oeconomus" who was to compute the amount of rent paid to the administrator by the "emphyteutae" (persons holding land in emphyteusis)

1 Greg. Reg. II. 38. See Ewald's note on p. $13^{8}$.

2 Cod. Just. 1. 2. 24. 
and by the conductors (strictly those holding land on a locatio or lease for a term of years) and to examine the administrator's accounts. Each oeconomus having made up his accounts had to submit them to the inspection of the other oeconomi who signed them with the word "àvé $\gamma \nu \omega \nu$," and the accounts and money paid in were then passed on to the "arcarii" or treasurers of the Church. The oeconomi had to submit their accounts monthly or at least every two months. The chartularies who assisted the oeconomus with his accounts received one per cent. of the rents as fees, and were allowed also to receive one per cent. of the first year's rent for every lease in locatio drawn up by them and two per cent. for every lease in emphyteusis. The oeconomi and chartularies were not allowed to hold any church lands on leases of any kind.

In its main outlines this system is very similar to that of the Roman patrimony, but at Constantinople the duties of the Roman rectors seem to have been partly performed by the oeconomi. Probably owing to the settled government and easiness of communication in the East it was not necessary to have in every patrimony an official armed with all the powers of the Roman rector. At the same time it is probable that, as at Rome, there was a notary of the treasury appointed to scrutinise each rector's accounts and to perform some of the duties of the oeconomus. 


\section{CHAPTER III}

\section{THE ORGANISATION OF THE PATRIMONY}

$A$ SHORT outline has been given in the previous A chapter of the general system of administration by which the Roman Church governed its numerous patrimonies. We must now pass on to a more detailed consideration of the internal organisation of each patrimony and of the system of local govern- $\sum$ ment of which the rector was the immediate head.

Each patrimony, though a self-contained unit in itself, was for purposes of administration sub-divided into estates known as "massae." These massae however were not purely artificial divisions created for purposes of government, but represented in many cases the estates of the original donors who had presented them to the Church. Many of them retained the names of these donors or of previous owners, and names such as Massa Juliana or Massa Neviana are frequently found. At the same time we find that the laws which prohibited the coloni of one owner from migrating to the estates of another or intermarrying with the coloni on another's estate were in the case of the church lands applied to the coloni on different massae ${ }^{1}$. All this goes to show that on transference to the Church the large estates retained much of their old organisation and separate character, and probably any estate of considerable size would on its incorpora- -

${ }^{1}$ See Greg. Reg. Ix. 128 and Jaffé, Reg. 1023. 
tion with the patrimony be constituted a new massa. But by no means all the gifts of land to the Church consisted of large estates, and in the fifth and sixth centuries, after the fall of the old Roman nobility, most of the new land of the Church was acquired farm by farm and field by field. The convenience of the system by which each large estate formed a unit by itself led however to its extension to all land of the Church irrespective of its mode of acquirement, and the farms and lands which were not comprised in the large estates were grouped together for purposes of administration to form new massae. These artificial massae may often be distinguished by their names, which were descriptive of their situation or were drawn from one of the farms included ${ }^{\mathbf{1}}$.

The massae however were not the lowest or most commonly employed agricultural units; these were the "fundi" or farms into which each massa was sub-divided. This division of the land into fundi was very ancient, going back in effect to the earliest days of the Republic, and was deeply rooted in the agricultural life of the people.

The fundus was often, even in the time of Gregory, the property of one small owner, and represented, in all probability, the original holding of one of the old yeoman farmers of the Republic. Many an ancient possessor was commemorated in the names of the fundi; thus we find a fundus Manlianus, fundus Vettianus, and fundus Cornelianus (from the gentile name)

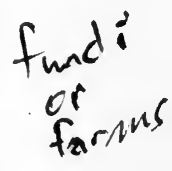

1 E.g. Massam aquas Salvias, Greg. Reg. XIV. I4, and the Massa Steiana from the fundus Steianus. 
and a fundus Festus, fundus Silanus and fundus Carbonis (from the cognomen); but, as in the case of the massae, many took their names from their situation or natural features ${ }^{1}$. Even where the small owners had been ousted and their farms swallowed up in the latifundia or large estates of the nobles, the fundus seems to have retained its identity as a useful'unit of division and, whether as a small estate by itself or as a unit in a massa, it became an integral part of the organisation of the church patrimony. Great care was taken to preserve the "individuality" (using the word in its strict sense) of the fundi and to prevent their absorption by one another. The boundaries of each fundus were carefully kept clear and were usually marked by boundary stones or " affines," and in conveyances and leases they are always described minutely, by their alternative names and their position with regard to the neighbouring farms ${ }^{2}$.

The massae and fundi were the only sub-divisions employed for administrative purposes, but we occasionally find other words used to describe fields and villages or other agricultural settlements. Thus the word "casale" is frequently employed. This (according to Tomassetti) was equivalent to a farm or group of farms on which the houses of the cultivators were gathered into a scattered village with some protection in the

1 E.g. fundus Saxonigro; fundus Quercetus, and cf. terrulae quae vocantur Fossa latronis, Greg. Reg. XIV. I4.

${ }_{2}$ E.g. Fundum Salianum cum omnibus suis pertinentiis situm in territorio Caesenate ad montem qui dicitur Lucati; $\mathrm{ab}$ uno latere situm iuxta fundum Carbasianum, $a b$ alio fundum Anianum, a tertio latere fundus qui dicitur Gumaris. Jaffé, Reg. 2192 . See also Greg. Reg. xIv. I4. 
form of walls or ramparts, and resembled the later "domusculta"; but while the domusculta was always an artificial foundation the casales were natural growths. The term however seems often used to refer to farm buildings or the dwellings of the coloni ${ }^{1}$.

We find also references to the "salae ${ }^{2}$ " or dwellings of the herdsmen who looked after the herds of oxen, horses and sheep.

Another term which is met with is "conduma." In a letter to Peter the sub-deacon Gregory ordered him to distribute 400 mares-one to each conductor in each conduma ${ }^{3}$. In another letter a certain bishop stated that a conduma which had been leased to him contained a small vineyard and he asked that this vineyard also might be leased to him ${ }^{4}$. From these two references it would seem that conduma means a farmstead. In addition to the houses of the conductors and the huts of the coloni and slaves, there were as a rule, on each massa, large barns for storing the corn purchased by the Church. On most massae there

1 In Greg. Reg. IX. I94 it is stated that a certain Ferrocinatus left to the church of S. John at Ortona "duos casales fundi, campos Etausimanos." It is plain that here casale is not equivalent to fundus but is some division of land smaller than a fundus; here it would seem to mean a large field. The word is found in many of Gregory II's leases.

2 See Tomassetti, La Campagna Romana.

3 Greg. Reg. Ir. 38 .

4 Ibid. IX. I94. If, as Ewald contends, conduma is equivalent to fundus, it is plain that the vineyard, being included in the fundus, would have passed by the same lease and would not require a separate lease; but if conduma is taken as meaning farmstead and not as equivalent to fundus, it is quite reasonable to suppose that there was a small vineyard adjoining it and generally held with it, which yet did not pass with the lease of the farmstead and therefore required an additional lease. 
would be also a church, or at the least an oratory, and on some were situated monasteries or the church infirmaries called "xenodochia1."

The method of cultivation no doubt varied considerably. In Sicily a great proportion of the land was arable, and Gregory ordered Peter to disperse the herds of oxen and horses there and set the herdsmen to agricultural labour ${ }^{2}$. In Southern Italy there must have been much vine growing, and in the list of leases granted by Pope Gregory II there are mentioned olive yards (oliveta), osier beds (saliceta), meadows, woods, oak coppices (glandareta), and plough lands (terra sationalia) ${ }^{3}$.

Before entering on a discussion of the method of farming practised by the Church, it will perhaps be as well to deal shortly with the exact powers possessed by the Church in the disposition of its landed property. The Church was undoubtedly the absolute owner of all its property, but this does not necessarily I imply that it possessed all the powers enjoyed by private owners. The lands owned by the Church had been given to it by the donors for certain specific uses, charitable or religious, and when it seemed possible that these might be neglected by the Church, it became necessary for the State to step in and insist

1 Greg. Reg. I. 42.

2 Ibid. II. 38. Ita ergo tua experientia faciat, ut aliae (equae scil.) per conductores omnes sicut diximus partiantur, alias distrahe, et in nummum reduc. Pastores vero ipsos per possessiones ordina, ut ex cultura terrae ferre aliquid utilitatis possint.

3 Jaffé, Reg. 2190-2228. Water mills, "aquimolae," are also mentioned. 
that the intentions of the donors should not be disregarded. In this respect the position of the Church may be compared with that of Colleges or other Charities in England at the present time. Until the fifth century the Church seems to have possessed full powers of disposition in respect of its landed property, but the abuses which grew up during that century rendered necessary certain restrictions on the full power of alienation. Various other restrictions were imposed on the Church by the Emperors, but the law relating to ecclesiastical property was not fully codified till the time-of Justinian and it is with his laws alone that it is necessary to deal/Justinian at first definitely forbade under any circumstances whatever ${ }^{1}$, the perpetual alienation (whether by way of sale or donation) by the Church of any land belonging toit, but by a subsequent enactment he allowed alienation in cases where a church was heavily indebted and where there was no possibility of liquidating the debt except by some sale of its property ${ }^{2}$; and also in the case of worthless or burdensomeland ${ }^{3}$. Such a sale however was only to take place after it had been sanctioned by the clergy of the church in question, the bishop and the metropolitan. The sale of the sacred vessels or plate of the Church was allowed for the purpose of redeeming captives, provided the consent of the metropolitan had

1 Just. Novel. vir. c. I. Alienationis nomen generalius ideo posuimus ut prohibeamus et venditionem et donationem et commutationem et in perpetuum extensam emphytiosin quae non procul ab alienatione consistit.

2 Ibid. XLVI. c. I and cxx. c. 6.

3 Ibid. cxx. c. 7. 
been obtained ${ }^{1}$. The Church was forbidden to exchange its lands with any private owner, but exchange was allowed with the State; fictitious exchanges with the State for the ultimate purpose of exchange with private persons were strictly forbidden ${ }^{2}$. Subsequently however the exchange as well as the sale of worthless or inconveniently situated land seems to have been allowed with the consent of the metropolitan ${ }^{3}$. The Church was thus deprived of the full power of alienation, but that limited form of alienation which is comprised in the granting of leases was allowed under certain conditions, and it was by means of leases that the Church farmed its lands and obtained a great part of its revenues.

The two contracts in Roman Law which roughly corresponded to the English lease were those known as "locatio" and "emphyteusis". W Whe contract known as "locatio" corresponds closely to the old form of the lease for a term of years. By this contract the land was hired by the lessor (locator) to the lessee (condyctor) for a specifiedrerm of years in consideration of an annual rent. The tenant had no right "in rem," and if ejected unjustly could only bring an action against

1 Just. Novel. viI. c. 8 and cxx. c. Io. See Greg. Reg. vir. I3 for an example of the papal consent to such a sale.

2 Just. Novel. vir. c. 2.

3 Ibid. cxx. c. 7. Hoc vero iubemus...licentiam esse omnibus sanctissimis ecclesiis quam in diversis provinciis constitutis permutationes ad invicem facere. See Greg. Reg. XIV. 3 where Gregory as metropolitan gives permission to the Bishop of Panormus and his clergy to exchange some ruinous and valueless house property of theirs in Rome for property of the Roman deacon Epiphanius.

4 See Hunter's Introduction to Roman Law, pp. 68-7o, I I 8-120. 
the landlord for breach of contract; he could not recover possession of the land 2 By the contract of emphyteusis in its usual form the land was leased to the tenant (emphyteuta) in perpetuity, in return for an annual payment to the landlord or his successors in title. The tenant had a right in rem and could deal with the property in any way he liked so long as he did not depreciate it. The emphyteuta was liable for the imperial and local taxes on the land, and could be ejected if he failed to pay these or to pay his rent for three years. Justinian by his legislation considerably curtailed the powers of the Church in granting leases both in locatio and in emphyteusis. Leases in locatio were not to be made for a longer period than thirty years or the life of the lessee ${ }^{\mathbf{1}}$, and lands were not to be let in emphyteusis for more than three successive lives, nor was the rent of the emphyteuta fo be reduced by more than one-sixth, even though the property leased had been damaged or had deteriorated in value $^{2}$. In the case of lands let in emphyteusis, if the rent was not paid for two years in succession or if the tenant neglected the property, the Church might

1 Just. Novel. cxx. c. 3. Locationes vero ab ipsis venerabilibus domibus fieri concedimus in quantoscunque contrahentibus annos placuerit non transcendentibus videlicet triginta annorum tempus. This law only applied to the churches under the patriarchal see of Constantinople but it was customarily observed in Italy by the popes.

2 Ibid. viI. c. 3. r. Cf. Greg. Reg. Ix. I9o where Gregory refers to a piece of land which had been let to a certain Adeodatus who had built a house upon it and now requested a reduction of his rent. Gregory instructed the rector to grant his request but reminded him that at the expiration of the term house as well as land would revert to the Church. 
re-enter ${ }^{1}$. Lands might be let in perpetual emphyteusis by one ecclesiastical body to another, but on no account was the emphyteusis to pass to private persons ${ }^{2}$.

The limitation of grants in emphyteusis to three successive lives destroyed the element of perpetuity which had been its most distinctive feature, and seems to have led, by the time of Gregory, to a practical assimilation of the two forms of lease. The tenant, whether in emphyteusis or under a locatio, is invariably termed conductor, and though it would seem from a reference in one of Gregory's letters that most of the conductors were strictly tenants in emphyteusis $^{3}$, the word emphyteusis is used very rarely by Gregory, and the phrase which he generally employs to describe the leasehold tenure of lands " "tenere libellatico iure" or "sub specie libellorum ") 4 might apply as well to a lease by locatio as to one in emphyteusis. No leases granted by Gregory are extant, though his letters contain references to them, and in one case an

1 Just. Novel. vir. c. 3. 2.

2 Ibid. Lv. c. 2. By Novel. cxx. c. 6 grants in perpetual emphyteusis were allowed if they were advantageous to the Church. But advantage does not seem to have been taken of this in Italy, and the only grants of land in perpetual emphyteusis of which there is mention were made to religious bodies, e.g. a lease in perpetuity to the diaconia of S. Eustachius made by Gregory II. Jaffé, Reg. 22I3.

${ }_{3}$ Greg. Reg. I. 42 where Gregory states that the rector's officials often prevented the heirs of conductors from succeeding to their farms. This must apply to conductors holding farms in emphyteusis for three lives.

4 E.g. ibid. Ix. 78 ; in 1. 7 o however Gregory says " multi vero hic veniunt qui terras aliquas... . in emphyteusin sibi postulant dari." 
instruction to a defensor to draw up a lease ${ }^{\mathbf{1}}$ : but considerable numbers of leases granted by Popes Honorius, Gregory II and Zacharias ${ }^{2}$ are extant, and it is plain from these that the distinction between locatio and emphyteusis had quite disappeared from the minds of those who drew them up. The tenure is essentially the same in all cases, and the various leases could only be classed as being in locatio or in emphyteusis according to whether the term is for one life or twenty-nine years (the usual term of years for a locatio) or for the three lives for which lands might be granted in emphyteusis ${ }^{3}$.

The extant leases of church lands by Popes Honorius, Gregory II and Zacharias are of great interest. They all follow more or less closely the same

1 Greg. Reg. Ix. 194.

2 Jaffe, Reg. 203I-2036, 2 I90-2228, 2297-2302.

3 It may be mentioned here that there was another system of tenancy in Roman Law by which the possession and the right to the profits of the land (the usufruct) were held by one person while the ownership of the land remained with another. This system was similar to the English tenancy for life of settled estates and was used for the same purposes. It was usually created by deed and for the term of one life, and the person holding the usufruct (the usufructuary) paid no rent. Such a system was obviously unsuited for church lands, but it seems that some bishops had granted the usufruct of church landsit may be presumed to their relatives or friends. Justinian enacted (Novel. cxx. c. 9) that the usufruct of church lands should only be granted on the condition that the usufructuary should make over to the Church a piece of land of equal value to that which he received, and that on the death of the usufructuary the land the usufruct of which had been granted should revert to the Church, which was also to retain the piece which had been made over to it by the deceased usufructuary. It may be presumed that this enactment put a speedy stop to the granting of church lands in usufruct; at any rate this system is never referred to in any papal letters.

S. P. 
form, though the terms were of course often varied by agreement: the document opens with a recital that the transaction is for the benefit of both parties, then follow the operative words of the lease "locavimus" or "concedimus," then the parcels (to use the English legal term), then the term of years and the rent. In some leases this is followed by a covenant for quiet enjoyment, and in leases of houses there is generally a covenant by the tenant to repair. In some leases there is a proviso for re-entry on non-payment of the rent $^{1}{ }^{1}$ and the lease usually ends with a statement that at the end of the term, or falling in of the life, the premises will revert to the Church without compensation being given for the tenant's improvements ${ }^{2}$.

1 The right of re-entry on non-payment of rent was not dependent on the proviso in the lease and existed quite apart from it. See above.

2 The following lease by Gregory II to Stephen the priest and two other persons in succession is such a good example that I quote it in full.

Gregorius Stephano presbytero atque aliis successim duabus personis. Quotiens illa a nobis tribui sperantur quae rationi incunctanter conveniant, animo nos decet libenti concedere, et petentium desideriis congruum impertire suffragium. Ideoque quia postulasti a Nobis, quatenus fundum Campanianum cum domo sua et vinea posita via Flaminia quatuordecim plus minus milliario ab hac urbe Roma, quod tenuit per emunitionem Sergius presbyter et vestiarius noster, qui fundus existit ex corpore Patrimoniae Tusciae iuris Sanctae Romanae, cui Deo auctore deservimus, Ecclesiae, hunc vobis emissa praeceptione ad tenendum concedere deberemus. Inclinati itaque precibus vestris per huius praecepti seriem, supradictum fundum cum domo et vinea et omnibus ei pertinentibus in integro a praesenti octava indictione diebus vitae vestrae vobis concedimus detinendum, ita sane ut a vobis singulis quibusque indictionibus pensionis nomine rationibus ecclesiasticis tres auri solidi difficultate proposita persolvantur, omnemque qua indigent meliorationem ac defensionem praedictus fundus et vinea seu domus indifferenter a vobis sine dubio procurant, 
The leases of church land which are extant all seem to have been granted by the Popes personally and signed by them, but they are all of lands near the city; it was quite plainly the practice, however, for the rectors in some patrimonies to grant leases at their own discretion, subject of course to papal supervision, and there is included in Liber Diurnus a "praeceptum auctoritatis de faciendis chartulis," or a formula giving authority to the rector to grant leases'.

The word conductor, though strictly meaning a person to whom lands were leased, seems to have been used sometimes in a wider sense, as it is not unusual to find references to conductors who were of servile standing; thus in a letter of Gelasius to Honorius ${ }^{2}$ there is a reference to "Ampliatus conductor quem non solum servum constat ecclesiae sed ita rationibus a multis temporibus implicatum ut etiam esset ingenuus...obnoxius haberetur"; and in a letter of Gregory to Peter the sub-deacon mention is made of Felix "conductor domnae Campanae quem liberum reliquerat et esse indiscussum iusserat ${ }^{3}$."

Since slaves possessed no legal standing, they cannot have held land on lease, and it is plain that the word conductor was extended by analogy to persons

efficiantur, nullaque postea ad dandum annuae pensionis a vobis mora proveniat sed ultro Actionariis Sanctae nostrae Ecclesiae apto tempore persolvatur. Nam si aliter, quod absit, a vobis provenerit de supra scripta melioratione et annua pensione statuimus fore invalidam hanc nostram praeceptionem. Post obitum vero vestrum memoratus fundus ad ius Sanctae nostrde Ecclesiae, cuius est proprietas in integro revertatur. Dat. Id. Aprilis. Indict. virr. Ann. Dni. III. (Jaffé, Reg. 2173).

1 Lib. Diurn. 34. 35.

2 Jaffé, Reg. 738. Migne, 59, p. I47. 3 Greg. Reg. I. 42. 
who were really bailiffs or stewards and managed the land on behalf of their masters. It would appear from this that before the time of Gregory not all the church land was let out on lease, but that some was retained by the Church and managed by stewards set over the coloni and appointed by the rectors. It does not seem probable however that much land was retained by the Church in its own hands, and this system of direct farming was gradually replaced, where possible, by the more convenient method of leasing out the land and throwing the burden of the management of both the land and the coloni on the tenants.

This is borne out by the fact that the references to these conductors of servile status occur mostly in the early papal letters, where the whole tone of the references to the conductors seems to show that they were not persons of much consideration. By Gregory's time the Church seems to have had no difficulty in securing tenants ${ }^{1}$, and as there are no references to church conductors of servile status in his letters, we may assume that the system of farming by stewards had already disappeared. The status of the freeconductors themselves seems to have improved with the increasing competition for leases of church lands. Gregory states that many came to Rome desiring to hold the islands and lands of the Church in emphyteusis and that he granted leases to some but refused others ${ }^{2}$.

1 See Greg. Reg. I. 70.

2 Ibid. 1. 70. Here and throughout when dealing with the conductors the word will be taken to include those holding land in emphyteusis as well as the holders of locationes, since, as has been explained above, there was at this period little or no difference between the two systems of tenure. 
$\mathrm{He}$ also states that he will on no account grant a lease disadvantageous to the Church, or grant anything "sine reservatione." In another letter ${ }^{1}$ Gregory mentions that the recruiting officer (scribo) Gentio has asked for a lease of church land, but that he has been obliged to refuse the request, since, though Gentio personally is a good man, the scribones generally bear a bad reputation. The Church was now plainly able to pick and choose its tenants and refuse any but persons of the most satisfactory character. In the list of leases granted by Gregory II we find that the lessees are all persons of some standing; there are tribunes, priests, a notary and his wife, nuns, soldiers, the head imperial cook (praepositus coquinae dominicae), a consul, country gentlemen (viri honesti) ${ }^{2}$, independent ladies (honestae feminae) and deacons. Theodore the consul leases the island of Capri at the rent of rog solidi and roo megarici of wine annually ${ }^{3}$, and there are some leases to monasteries in perpetuity 4

This anxiety on the part of the Church to obtain conductors of high standing was very natural, as the conductors were liable not only for their own rent but for the rent or pensio of the coloni (the agricultural labourers) on the lands leased to them. They were liable also for the maintenance of discipline among the coloni and for the good cultivation of the land. The Church did not however always treat the con-

1 Greg. Reg. Ix. 78. Quoniam filius noster Gentio vir magnificns scribo tantae Deo propitio bonitatis est, ut valde sit diligendus, si quid potuissemus ei conferre, debuimus.... Sed propter malos scribones iudicavimus in hac nos causa nec bono committere.

2 Jaffé, Reg. 2190-2228. ' ' Ibid.2216. ' Ibid.2213,2220. 
ductors fairly and they were subject to oppression by the church officials. Thus Gregory states that when conductors died their heirs were sometimes not allowed to succeed to the inheritance, and the property of the deceased persons was seized by the Church. He forbade this for the future 1 .

We must now consider the position of the cultivators of the soil, to whom the wealth of the Roman Church was chiefly due. This labouring population of the Patrimony was composed of two classes-the slaves, and the persons known generally as coloni ${ }^{2}$ -and it is necessary to give here some account of the circumstances which gave rise to the growth of the latter class. During the Republic and the early Empire the large estates of the Roman nobles had been cultivated by slave labour, and between the slave and the freeman there was no intermediate class. Towards the end of the second century and during the । third century A.D. the depopulation of the Empire, which afterwards became so marked, began, and from the time of Marcus Aurelius onwards it became the

1 Greg. Reg. I. 42. Cognovimus etiam, quod quibusdam conductoribus morientibus parentes sui non permittuntur succedere, sed res eorum ad usum ecclesiae pertrahuntur. De qua re definimus, ut parentes morientium qui in possessione ecclesiae degunt heredes eis accedere debeant, nec aliquid de substantia morientium subtrahatur. This must refer to conductors holding land in emphyteusis for three lives. Apparently after the death of the first emphyteuta the rector's officials refused to allow the second or third heirs to enter into possession of the land.

2 The name colonus is that most frequently used, but the words inquilinus (meaning originally the tenant of a town house), adscriptitius (a person bound to the soil), tributarius and censitus (a person entered in the tax books) and originarius (a colonus by birth), as well as the more general word rusticus, are all used as synonyms for colonus. 
practice of the Emperors, when victorious in their frontier wars, to settle large numbers of conquered barbarians on waste lands in the heart of the Empire. These barbarians were not enslaved; they remained personally free, but they were forbidden to remove from the land on which they were settled and were known as coloni ${ }^{1}$. Another cause contributed to the spread of the colonate in Italy. At the end of the third century A.D. the ancient "ius Italicum, " or exemption of Italy from taxes, disappeared, and the lands of Italy were subjected, as were those of the other provinces, to the crushing burden of the land tax. In order to pay this it became necessary for the large owners of Italy to cultivate more attentively their latifundia which had been previously used almost entirely for grazing ${ }^{2}$. This of course necessitated a larger supply of labour; but already, after the cessation of wars of conquest, the supply of slaves had begun to fall off and labour was getting scarce. The new institution of the colonate offered a welcome means of obtaining labour while at the same time rendering

1 They were also known as "dedititii " or "datitii." For such a settlement of barbarians as coloni see Cod. Theo. v. 4. 3 . The process was still going on in Gregory's time, since he thanked the exarch Gennadius for having settled datitii as coloni on the lands of the Roman Church in Africa (Greg. Reg. I. 73). Savigny at first held that the coloni were originally slaves who had been granted a modified freedom and that their numbers were later increased by freemen who sank to that position (Der römische Colonat, p. 48), but he was later converted to the view of the origin of the colonate which is given above.

2 In this account of the origin of the colonate I have chiefly followed Tomassetti in the account given in his book $\mathrm{La}$ Campagna Romana. 
$\checkmark$ easier the payment of the tax, and it began to spread enormously. Henceforward, from the time of Constantine onwards, every Emperor, when victorious over attacking barbarians, made settlement on the lands of the Empire one of the terms of peace, and barbarians were even induced to settle in the provinces by offers of land. During the fourth century hundreds of thousands must have thus settled in the Empire.

It is no doubt to these settlements of barbarians that the origin of the colonate was chiefly due, but during the fifth and sixth centuries the ranks of the coloni were swelled by many freemen who sank to that position and also by slaves who rose to it. Salvian states that through the pressure of taxes many freemen became coloni on the lands of the rich ${ }^{1}$. There seems to have been some distinction however between freemen who voluntarily performed the duties of coloni and the original coloni. A law of Anastasius states that some coloni were bound to the land and their peculia or personal property belonged to their lords, but that others had become coloni through remaining as such for thirty years; these remained free and retained the control of their property though they paid the capitatum or poll tax and could not leave the land ${ }^{2}$. A subsequent law of Justinian explained

1 Salvian, De gubernatione Dei, lib. v. cc. 8 and 9. Free and sturdy beggars might be punished by being made coloni. Cod. Just. XI. 25. I.

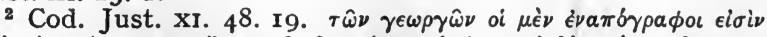

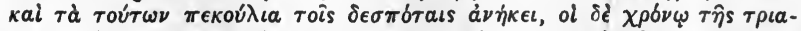

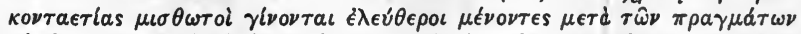

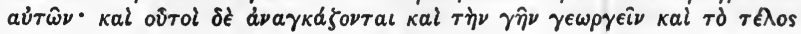


the position of these persons. Though they were bound to the land they remained free, and their children were free though also bound to the land ${ }^{1}$. This law is important as showing that by the time of Justinian the position of the original coloni had become one by itself, neither free nor slave ${ }^{2}$, since, if the coloni were regarded as still personally free, there would be no distinction between persons born coloni and free persons who by prescription were bound to fulfil the duties of coloni. The importance of the distinction seems to have been that these free coloni were entitled to the protection of the imperial courts, as the law goes on to prescribe that the judges were to see that the privileges of such persons were not infringed. At the same time the law bears eloquent testimony to the assimilation of the status of the original coloni to that of slaves ${ }^{3}$, and this tendency was probably

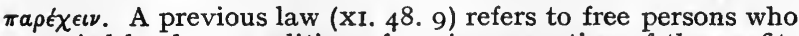
occupied land on condition of paying a portion of the profits to the owner. The position of such persons seems to have been somewhat similar to that of the free coloni mentioned above and they also probably tended to become coloni.

1 Cod. Just. XI. 48. 23.

2 There seems no reason to doubt that the coloni were origin. ally regarded as personally free, but by this time they were certainly not so regarded though their status was still distinguished from that of slaves (see the law regarding the intermarriage of slaves and coloni). It seems to me that at this period the coloni were regarded as being really servile, but that the law defined and regulated, and to a certain extent safeguarded, their position, while it still disregarded the existence of slaves, who were considered as chattels and not human beings. On the other hand the fact that the coloni paid taxes certainly helped to maintain their original status as freemen. It seems best to regard them as forming at this period a class by themselves, intermediate between freemen and slaves.

3 The following striking words occur in a law of Justinian (Cod. Just. XI. 48, 2I). Quae etenim differentia inter servos 
assisted by the fact that many slaves seem to have risen to the position of coloni.

The status of a colonus was inherited, and the children of the coloni were also coloni and bound to the soil of their lord. In the case of intermarriage between coloni and free persons, when the mother was a colona the children followed her status, but when the mother was free and the father a colonus the children were also coloni. Marriage between free women and coloni was considered disgraceful and the colonus might be forcibly separated from his wife ${ }^{1}$. In the case of intermarriage between coloni and slaves the children always took the status of the mother ${ }^{2}$.

It seems that originally a colonus who had left his lord's land and lived for thirty years as a freeman, unclaimed by his lord, became free ${ }^{3}$, but this privilege was abolished by Justinian and no prescription seems to have availed to shake off the status of a colonus $4_{3}$.

Such was the origin of the coloni. Their position was superior to that of slaves, though the later form of the colonate seems to have been less advantageous than the earlier and there was a tendency to assimilate the status of coloni and slaves. With regard to the features that marked the status of the colonus,

et adscriptitios intelligetur cum uterque in domini sui positus est potestate et possit servum cum peculio manumittere et adscriptitium cum terra suo dominio expellere? This rhetorical question should not however be taken too literally and it may be noted that no reference is made to the lord's power over the peculium of the adscriptitii.

1 Just. Const. de adscriptitiis. Formerly when the mother was free the children were also free. Cod. Just. XI. 48. 24.

2 Cod. Just. ibid.

- Cod. Just. xI. 48. 33.

3 Nov. Val. tit. 30. 
the most characteristic was the fact that he was bound to the soil. The colonus, in fact, like the mediaeval villein, formed part of the estate on which he dwelt and a conveyance, or lease, of the land transferred to the purchaser, or lessee, all rights over the coloni ${ }^{1}$ dwelling on it. If part of an estate was sold, a certain number of coloni, proportionate to the size of the part sold, passed with the land; and though an owner of two estates might move some of his coloni from one to the other, the coloni when they had been moved formed part of the first estate, and the owner could not cheat a purchaser by moving, to other land retained by him, coloni who had been settled on an estate before the sale ${ }^{2}$.

But though the colonus had no proprietary right in the soil, the fact that the lord could not sell the land without the colonus gave the latter a position not far removed from ownership ${ }^{3}$. Being bound to the soil the coloni were not allowed to remove from the lands of their lord, and coloni who had fled from their homes were sought out and brought back. The laws on this point were very strict, and persons who knowingly harboured a fugitive colonus were liable to heavy

1 Cod. Just. XI. 48. 2. Si quis praedium vendere voluerit vel donare retinere sibi transferendos ad alia loca colonos privata pactione non possit. Qui enim colonos utiles credunt aut cum praediis eos tenere debent aut profuturos aliis derelinquere si ipsi sibi praedium prodesse desperant.

2 Cod. Just. XI. 48. 7. A law of Gratian and Maximus.

3 This is pointed out by Savigny in his essay on the colonate.

E.g. Cod. Just. xI. 48. 6 (a law of Valentinian and Valens). Omnes omnino fugitivos adscriptitios colonos vel inquilinos sine ullo sexus muneris conditionisque discrimine ad antiquos penates ubi censiti atque educati natique sunt provinciis praesedentes redire compellant. 
fines ${ }^{1}$. In the case of the church lands the massa represented the estate of one private owner and coloni were not allowed to move from one massa to another. The rector of each patrimony was empowered to seek out and recall fugitive coloni or thosé who had left one massa for another ${ }^{2}$, and the coloni were always reminded of this in the letters sent to them on the appointment of a new rector ${ }^{3}$. But the Church was no more successful than the private owner in preventing altogether the migration of coloni, and so considerable was the demand for labour that in one instance recorded by Gregory the neighbouring landowners seem to have enticed away the coloni of the church of Cagliari to their own estates, with the result that the church lands being left uncultivated could not pay the imperial land tax (tributum $)^{4}$.

In pursuance of the principle of retaining the coloni on the land at all costs, the coloni of one owner were forbidden to intermarry with those of another, and where this occurred in defiance of the legal prohibition, the children were to be divided equally among

1 By a law of Honorius and Arcadius a fine of twelve pounds of silver was inflicted on persons knowingly harbouring fugitive coloni. Cod. Just. XI. 48. I2.

${ }^{2}$ Lib. Diurn. 53. Noveritis enim sub hac conditione vos esse commissos, ut mancipia si qua foris latitant, vel fines pervasos sua instantia iuri ecclesiastico revocare non differat.

3 E.g. Greg. Reg. Ix. 3o. The words used are almost exactly similar to those quoted above from the formula in Liber Diurnus.

- Greg. Reg. IX. 203. Dictum etiam nobis est, quod rustici possessionis eiusdem Caralitanae ecclesiae rura propria deserentes in privatorum possessionibus culturam laboris adhibeant. Ex qua re agitur, ut possessiones ecclesiae proprio in aliis occupato cultore depereant atque ad tributa sua persolvenda idoneae non existant. 
the two lords, but the husband and wife were not to be separated. Thus Gregory instructs Romanus, rector of Syracuse, to warn Peter a defensor, by birth a colonus, not to permit his sons to marry outside their massa or to remove from it ${ }^{1}$. On the church lands it was also the custom for the coloni to pay a small fine on the marriage of their daughters. Gregory ordered that this fine should be reasonable in amount, and on no account was it to exceed the sum of one solidus. In accordance with custom it was to be given to the conductors and not retained by the rector or church officials ${ }^{2}$.

The position of the colonus with regard to his chattels and personal effects was rather complicated. This property, like the savings and personal effects of slaves, was called peculium, and from some expressions employed it might be imagined that, as was the case with the peculium of slaves, it was legally the property of the master and not of the colonus ${ }^{3}$. Savigny however

1 Greg. Reg. Ix. I28. Hac tibi praeceptione mandamus, ut eum stricte debeas commonere, ne filios suos quolibet ingenio vel excusatione foris alicubi in coniugio sociare praesumat, sed in ea massa, qua lege ex condicione ligati sunt, socientur.... Nam si quis eorum exinde, quod non credimus, exire praesumpserit, certum illi sit, quia noster numquam concessus aderit, ut foris de massa, in qua nati sunt, aut habitare aut debeant sociari, sed super scripta terra eorum.

2 Ibid.I. 42. Pervenit etiam ad nos, quod de nuptiis rusticorum inmoderata commoda percipiantur. De quibus praecipimus, ut omne commodum nuptiarum unius solidi summam nullatenus excedat....Quod nuptiale commodum nullatenus volumus in nostra ratione redigi, sed utilitati conductorum proficere.

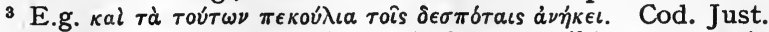
xI. 48. I9 and xI. 50. 2. Quem (colonum scil.) nec propria quidem leges sui iuris habere voluerunt et adquirendi tantum non etiam transferendi potestate permissa domino et adquirere et habere voluerunt. 
has shown that this was not the case ${ }^{1}$ and that the colonus was the owner of his peculium, though he could not alienate or transfer it without the lord's consent ${ }^{2}$. The peculium of such persons as had become coloni through prescription was not subject to these restrictions and could be dealt with by them at their pleasure ${ }^{3}$.

In criminal matters the colonus was subject to the jurisdiction of his master and not to that of the ordinary courts. This did not imply however that he could be punished like a slave at the mere whim of his owner. The colonus being free could presumably be punished only for offences against the law, but in his case the criminal jurisdiction of the State was exercised through the lord instead of through the ordinary courts. In cases where a crime had been committed against a colonus by his lord, the colonus was allowed to seek redress in the imperial courts ${ }^{5}$. On the church estates this jurisdiction was exercised by the rector, and Gregory directed that corporal punishment or imprisonment should as a rule be inflicted rather than

1 Savigny, Der römische Colonat, pp. 29, 30.

2 Cod. Theo. v. II. I. Non dubium est colonis arva quae subigunt usque adeo alienandi ius non esse, ut et si qua propria habeant inconsultis atque ignorantibus patronis in alteros transferre non liceat. Cod. Just. XI. 50. 2. Cum enim saepissime decretum sit ne quid de peculio suo cuiquam colonorum ignorante domino praedii aut vendere aut alio modo alienare liceret.

3 Cod. Just. XI. 48 . I9.

4 Fugitive coloni could however be punished by being put in irons; a punishment reserved as a rule for slaves. Cod. Theo. v. 9. I. Ipsos etiam colonos qui fugam meditantur in servilem conditionem ferro ligari conveniet.

5 Cod. Just. XI. 50. 2. Ita in criminum accusatione quae publica est non adimitur eis (colonis scil.) propter suam suorumque iniuriam experiendi licentia. 
fines-probably because the latter led to extortion and corruption on the part of the judges ${ }^{1}$. In civil cases the colonus had apparently a right of action in the imperial courts, but against his lord he had no such right except in the one case of arbitrary increase of his rent or pensio (superexactio) ${ }^{2}$. This immunity of the lord and absence of legal protection for the coloni must have greatly increased the tendency to assimilate the status of coloni and slaves. It is significant that by the end of the sixth century men had begun to talk of the "freeing" of a colonus, as is illustrated by the following quotation from Gregory's Dialogues: "Venantii quondam patricii in Samnii partibus villa fuit in qua colonus eius filium Honoratum nomine habuit a praedicto domino suo libertate donatum ${ }^{3}$."

Besides being bound to the land of their lord the coloni had also to make him an annual payment from the produce of their land. This payment was known as the "canon" or "pensio." On the land of private owners it was paid by the coloni to the landlord directly, but on the lands of the Church it was paid to, or rather collected by, the conductors, and then handed over by them to the rector ${ }^{4}$. It was as a

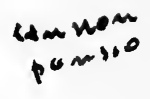

1 Greg. Reg. I. 42.

2 Cod. Just. xI. 50. I (a law of Constantine). See also ibid. xI. 50. 2. Sed ut in causis civilibus huiusmodi hominum generi adversus dominos vel patronos et aditum intercludimus et vocem negamus exceptis superexactionibus in quibus retro principes facultatem eis super hoc interpellandi praebuerunt. The express mention of the lords seems to show that the coloni were not forbidden to bring civil actions against other persons.

3 Greg. Dialogues, lib. I. c. I

- See Greg. Reg. v. 3I, where in a letter to the conductors of 
general rule paid in kind except on those estates where there was a custom to the contrary ${ }^{1}$. Such a custom seems to have obtained on the church lands, and the pensio of the church coloni was paid in money ${ }^{2}$. According to some writers ${ }^{3}$ the pensio consisted of a fixed percentage of the fruits of the earth if paid in kind, or the value of such a percentage if paid in money. It seems plain however, from the instructions given by Gregory to the rectors of two patrimonies to fix the amount of pensio payable by each colonus, that the real basis of calculation was the size of each man's holding and not a percentage of produce 4 . On the church lands the collection of the

the Gallic patrimony Gregory instructs them to appoint one of their number to take charge of the pensiones which they have collected from the coloni until the rector Candidus comes to receive them.

1 Cod. Just. xI. 48. 5 (a law of Valentinian and Valens). Domini praediorum id quod terra praestat accipiant pecuniam non requirant, quam rustici optare non audent nisi consuetudo praedii hoc exigat.

${ }^{2}$ Ewald plainly shows in his note on Greg. Reg. I. 42, p. 62 that the pensio was paid in money and that Gregory's words refer to money payments not to payments in kind. He instances also Jaffé, Reg. 666, 667, where receipts given by Gelasius to conductors state that they have paid in "ex fundis de fructibus anni praecedentis auri solidos $30 . "$

3 According to Grisar it was calculated on the basis of one measure in thirty-five or nearly three per cent., but he seems to have confused it with other payments mentioned by Gregory, in particular with the payment of $73 \frac{1}{2}$ solidi to the libra about to be referred to.

- See Gregory's instructions to Peter to give each colonus a document stating his assessment, and his words to Savinian of Callipolis (IX. 206): Volumus etiam... et adhibita sollicitudinis cura uniuscuiusque vires, quid praestare de sua pensione ecclesiae utilitatibus valeant, caute cognoscere ac secundum vires suas ad persolvendum quemque disponere. All this would have been quite unnecessary if a fixed percentage had been paid by all. 
pensio seems to have been accompanied by much extortion on the part of the officials. In his famous letter to Peter the sub-deacon concerning the patrimony in Sicily, Gregory states that on some massae the coloni were forced, when paying the pensio, to pay at the rate of $73 \frac{1}{2}$ solidi to the pound of gold (libra) instead of at the ordinary legal rate of 72 solidi to the libra ${ }^{1}$. This evil custom was an imitation of that followed by the state officials in collecting the taxes, and its alleged justification was the fact that, the taxes being paid by weight, and many of the coins being old or of short weight, it often happened that 72 solidi would not weigh the full pound, and it thus became necessary to add certain solidi to make up the deficiency $^{2}$. The Church, however, was an easier master than the State, for by a law of Constantine the reckoning, in tax-paying, was to be 84 solidi to the pound ${ }^{3}$; this was known as the "libra maior." Gregory hints that at times even this was demanded 4 ; and it was the practice on some estates to demand a slightly higher rate ${ }^{5}$. In addition to this the coloni were forced to make certain other small payments (minuta onera) and to pay a small impost called "granaticum," which

1 It may be as well here to give the Roman monetary table at this period. 4 grana $=I$ siliqua. 24 siliquae $=I$ solidus. 72 solidi $=\mathrm{I}$ libra. Ioo librae $=\mathrm{I}$ talent. The solidus was also divided into 3 tremisses of 8 siliquae each.

2 Cf. Cass. Var. II. 25. ${ }_{3}$ Cod. Theo. XII. 7. I.

4 Greg. Reg. 1. 42. Neque libram maiorem neque onera supra libram maiorem exigi debeant.

5 Ibid. Cognovimus etiam, in aliquibus massis ecclesiae exactionem valde iniustissimam fieri, ita ut libram septuagenum ternum semis quod dici nefas est exigantur (rustici scil.) et adhuc neque hoc sufficit, sed insuper aliquid ex usu iam multorum annovum exigi dicuntur.

S. P. 
was perhaps a payment of one or two grains per solidus ${ }^{1}$. Gregory determined to put an end to these abuses" on the church estates. He ordered Peter to reckon up the amount which was brought in by the addition of $\mathrm{I} \frac{1}{2}$ solidi to the libra and by the other small payments, and to add this amount to the sum total of the pensio. The extra payments themselves were to be utterly abolished, and the pensio was never to be paid at a higher rate than the ordinary legal one of 72 solidi to the pound ${ }^{2}$. Thus the Church did not lose, and the coloni knew where they stood and were saved from the extortion which is always incident to undefined claims. Gregory feared, however, that after his death these payments might again be demanded, while the pensio would still remain at the higher rate due to the addition of the sum for which they had been commuted, and that thus the last state of the coloni would be worse than the first. To prevent this he ordered Peter to give each colonus a document stating exactly what was the sum total of the pensio payable by him ${ }^{3}$. Thus the rector had been used to

1 Greg. Reg. I. 42. Abiectis siliquis, oneribus, vel granaticis.

2 Ibid. Sed tua experientia sive in hoc quod per libram amplius, sive in aliis minutis oneribus et quod ultra rationis aequitatem a rusticis accipitur, penset et omnia in summam pensionis redigat, ut prout vires rusticorum portant pensionem integram et pensantem libram septuagenum binum persolvant, et neque siliquas extra libras... exigi debeant, sed per estimationem tuam prout virtus sufficit in summam pensionis crescat et sic turpis exactio nequaquam fiat.

3 Ibid. Ne vero post obitum meum haec ipsa onera, quae super pensum inlata subtrahimus et in capiti pensionis fecimus crescere, iterum in quolibet addantur et inveniatur et summa pensionis augeri et onera adiectionis insuper rustici solvere compellantur, volumus, ut securitatis libellos ita de pensionibus 
receive certain small payments from the coloni for himself; these Gregory wished Peter to discontinue and to compensate himself by taking instead a certain sum out of the total pensio ${ }^{\mathbf{1}}$; he also did not wish Peter for the future to receive any little gifts of small fields or of wine ${ }^{2}$. Great care was also to be taken that false weights were not used when weighing the solidi paid in for the pensio; the previous rector Servus-dei had found such weights, and Peter was ordered to seek them out and destroy them ${ }^{3}$; nothing was to be demanded above the just weight except a small payment called "vilicilia," which was probably a gratuity given to the "vilicus," or agent who collected the pensio, and the payments in kind known as the "excepta" which will be referred to in detail immediately ${ }^{4}$. It is to be noted that it was the Church, and not the conductors, who profited by these exactions, as is shown by the fact that Gregory did not abolish them entirely but commuted them for a sum which was added to the total of the pensio. That the church officials and not the conductors were the chief opfacias, quatenus inprimas, dicens, tantam pensionem unumquemque debere persolvere.

1 Ibid. Quod autem ex his minutiis in usu rectoris accedebat, volo ut hoc ex praesenti iussione nostra ex summa pensionis in usu tuo veniat.

2 Ibid. Rescellas et cellaria non plus de massis ecclesiae te accipere volumus.

3 Ibid. Ante omnia hoc te volumus sollicite adtendere, ne iniusta pondera in exigendis pensionibus ponantur. Sed si qua talia invenis, frange et nova et recta constitue, quia et filius meus Servus-dei iam talia invenit, quae ipsi displicerent. Sed licentiam haec inmutare non habuit.

4 Ibid. Super iusta pondera praeter excepta et vilicilia nihil aliud volumus a colonis ecclesiae exigi. For the vilici see Cass. Var. v. 39. 
pressors of the coloni is borne out also by Gregory's statement that, where a conductor had unjustly deprived a colonus of anything, this was taken from the conductor by the church officials, but was not restored to the colonus; in the future, objects thus taken were to be given back to their owners ${ }^{1}$.

$\checkmark$ The small payments in kind, called "excepta," seem to have been made by the coloni to the conductors and not to the Church or its officials, though it is true that in one case Gregory ordered them to be given to a certain noble, Arigius, who was acting as rector of the Gallic patrimony in the absence of the rector Candidus ${ }^{2}$. This case seems to be exceptional, however, and they were probably given to him as a special remuneration for his kindness in acting as rector. An example of these payments is given in a letter of Gregory in which he directs that a certain recruiting officer, Gentio ${ }^{3}$, whose request for a lease he has been obliged to refuse, is nevertheless to receive the excepta which he would have received if his request had been granted; they are stated to be 20 pigs, 20 sheep and 60 fowls.

The payments made to the Church were not the $\checkmark$ sole burden borne by the coloni; they had also to pay taxes to the State. During the later Empire the imperial revenue was derived mainly from two taxes, the poll-tax or "capitatio" assessed on all persons owning

1 Greg. Reg. 1. 42. Cognovimus etiam, quia quotiens conductor aliquid colono suo iniuste abstulerit, hoc quidem a conductore exigitur, sed ei non redditur a quo ablatum est.

2 Ibid. v. 3r. Visum nobis est, ut consuetudinaria excepta eius (Birgii scil.) utilitate debeatis inferre.

s Ibid. Ix. 78 . 
no land, and the land-tax or "tributum" payable by such persons as owned land. The dwellers in towns were specially exempted from the capitatio ${ }^{1}$, which thus fell almost entirely on the coloni and slaves. The names of all coloni and slaves were entered in the tax assessment books and from this liability of theirs to the poll-tax were derived the names of "censiti" and "tributarii" which were sometimes applied to them. The tax was collected by the landowner from his coloni and he was liable for its payment to the revenue officers. The poll-tax does not seem to have been very heavy, and it is not referred to in any of the papal letters dealing with the Patrimony ${ }^{2}$.

$\checkmark$ By far the greater part of the revenue was derived from the land-tax (jugatio or tributum). This was payable by all landowners, a fixed sum being assessed on a fixed unit of land. In theory, since the coloni owned no land and paid the capitatio, they were free from this tax, which was a burden on their landlord. As a matter of fact however the tax was so heavy that most landowners found it impossible to pay it out of their profits; on the lands of the Church and probably on those of many other landowners it was raised by compelling each colonus to bear a share of the total tax payable by the estate. Even so, owing to the heaviness of the tax, many smaller landowners were unable to pay, and either allowed their property

1 Cod. Theo. xirr. Io. 2.

2 For the system of taxation under the Empire see Savigny, "Über die römische Steuerverfassung unter den Kaisern." Vermischte Schriften, vol. II. The word capitatio is generally employed to mean the poll-tax but is sometimes used of the land-tax. 
to be seized by the Treasury, or, as Salvian relates, made over their lands to other persons, continuing to occupy the lands as tenants, or even themselves became coloni ${ }^{1}$ or slaves ${ }^{2}$ on the lands of the rich. Gregory tells us that in Corsica many unfortunate possessores were forced to sell their children into slavery or themselves to fly to the Lombards and so escape from the Roman dominions ${ }^{3}$.

The Church, in common with every other landowner, was forced to contribute its share to this oppressive tax, which is often referred to as the "debitum ecclesiae," and it seems that even the churches had difficulty in paying the tax. Gregory mentions that the church of Pagliari could not pay the tributum as its coloni had migrated to the lands of other owners ${ }^{4}$, and in the seventh century the Roman Church was unable to pay the land-tax on its patrimonies of Bruttium and Lucania, with the result that its coloni were seized by the revenue officials as pledges ${ }^{5}$.

This tax, which is called by Gregory the "burdatio" and was seemingly the same as the "trina illatio" so

1 Salvian, De gubernatione Dei, lib. 5. c. 8. Cum rem amiserint amissarum tamen rerum tributa patiuntur, cum possessio $\mathrm{ab}$ his recesserit capitatio (= tributum) non recedit? Proprietatibus carent et vectigalibus obruuntur.... Fundos maiorum expetunt et coloni divitum fiunt...iugo se inquilinae abjectionis addicunt.

${ }_{2}^{2}$ Salvian, op. cit. lib. 5. c. 9. Quos esse constat ingenuos vertuntur in servos.

8 Greg. Reg. v. 38.

4 Ibid. Ix. 203.

5 Lib. Pont. p. 369. In the time of Pope Agatho the Church had been unable to pay the land-tax for the patrimonies of Calabria and Sicily. Ibid. p. 366. 
often mentioned by Cassiodorus ${ }^{1}$, was payable annually in three instalments, and on the church lands it seems to have been the practice for the coloni to pay their share of the tax directly to the imperial officials instead of through the rector. Gregory says that in Sicily the first instalment of the burdatio, which was due in January, pressed very heavily on the coloni, as they had not yet sold the produce of their olive crop and were forced to borrow from moneylenders at exorbitant interest. In order to pay off these loans they had to sell their produce directly after harvest, often at low prices, instead of waiting for a favourable opportunity. He therefore instructed the rector, Peter, to lend money to the coloni from the church funds and to accept payment in instalments as the coloni were able to make them ${ }^{2}$. The care which Gregory thus showed for the coloni was strikingly illustrated when a certain Theodosius, an imperial tax collector, having collected one instalment of the burdatio, died without having paid the money into the treasury. The imperial officials at

1 Cass. Var. II. I7 etc. It was payable on the first day of January, May, and September.

2 Greg. Reg. 1. 42. Praeterea cognovimus, quod prima inlatio burdationis rusticos nostros vehementer angustet, ita ut priusquam labores suos venundare valeant compellantur tributa persolvere... . Unde. . . praecipimus, ut omne, quod mutuum pro eadem causa $a b$ extraneis accipere poterant, a tua experientia in publico detur et a rusticis ecclesiae paulatim ut habuerint accipiatur, ne dum in tempore coangustantur, quod eis postmodum sufficere in inferendum poterat, prius compulsi vilius vendant et horreis minime sufficiant. Grisar fittingly quotes E. Latters as follows: "dass also ein Papst das erste und älteste Beispiel gegeben habe von dem was jetzt die agrarischen Banken tun oder nicht tun sollten." 
once made the coloni pay the tax again. It appeared, however, that Theodosius had left enough effects to make good the amount of the tax, and Gregory instructed Peter, whether this were so or not, to repay to the coloni out of the church funds the second enforced contribution so that they might not be forced to pay the same tax twice ${ }^{1}$.

The extortions practised by the rectors and church officials in the payment of the pensio have been men tioned above, but it appears that the conductors also were not to be deprived of their share in the oppression of the unfortunate coloni. Large quantities of corn were required by the Church for poor relief and for distribution in Rome, and this was bought by the church officials in Sicily. It was the practice for the rector in Sicily to buy this corn from the coloni through the conductors, and it seems that these latter forced the coloni to sell cheap instead of at the market. price. Gregory was indignant at this form of oppression and he ordered that in future all corn should be bought at its full market value ${ }^{2}$. The conductors also forced the coloni to give a larger measure (modius) than the legal one of $\mathrm{I} 6$ sextarii, allowing for short measure on the same principle as was employed in the case of paying the pensio. Gregory permitted this custom to be retained so far that I 8 sextarii might be

1 Greg. Reg. I. 42. Theodosius is in some MSS called gl. m., i.e. gloriosus magister militum, and was thus an imperial official.

2 Ibid. Cognovimus rusticos ecclesiae vehementer in frumentorum pretiis gravari, ita ut instituta summa eis in comparatione abundantiae tempore non servetur, et volumus, ut iuxta pretia publica omni tempore, sive minus sive amplius frumenta nascantur, in eis comparationis mensura teneatur. 
demanded to the modius, but nothing in excess of this was to be demanded ${ }^{1}$ except the small amount of corn which by custom was supplied for the food of the sailors. We find, however, that his orders were not complied with; for, in a later letter, he stated that he had discovered that the conductors went so far as to demand a modius of 25 sextarii. At this he was so indignant that he ordered the defensor Pantaleo to seek out and destroy all the false measures and, where possible, to force the conductors to discharge their ill-gotten gains. The money so recovered was not to be retained by the Church, but was to be employed in buying cows, sheep and pigs to be distributed among the poorer coloni ${ }^{2}$.

According to the Roman law the risk of goods, while in transit, was on the seller, and thus when corn sent to Rome was lost at sea the coloni had to make good the loss. Gregory, following the example of King Theodoric ${ }^{3}$, directed that this legal right should not be enforced and that the risks of the voyage should be borne by the Church.

1 Greg. Reg. I. 42. Valde autem iniustum et iniquum esse perspeximus, ut a rusticis ecclesiae de sextariaticis aliquid accipiatur, ut ad maiorem modium dare compellantur, quam in horreis ecclesiae infertur. Unde... praecipimus, ut plus quam decem et octo sextariorum modium numquam a rusticís ecclesiae frumenta debeant accipi, nisi forte si quid est, quod nautae iusta consuetudinem superaccipiunt, quod minui ipsi in navibus adtestantur. Ewald thinks that the sextariaticum was some sort of payment; but surely it refers to the measures used in buying the corn?

2 Ibid. XIII. 37.

3 Ibid. I. 42. Frumenta autem quae naufragio pereunt per omnia volumus reputari. Cf. Cass. Var. Iv. 7 and I. I6 (remission of taxes to conductors of the royal domain whose crops had been burnt by enemies). 
The relations of the coloni to the conductors, so far as relates to the demands of the Church, have been explained above, but the personal relations of the coloni to the conductors on whose farms they were situated, are far from clear, as Grisar admits, and no writer, so far as I am aware, has attempted to elucidate it. The following is advanced as a tentative explanation.

It is plain from what has been said above that the conductors made no profit out of the pensio: this was exacted in full from them by the Church, while any gains they made in buying corn for the Church were certainly not legitimate and were suppressed by Gregory $^{1}$. At the same time they had not only to spend much time and labour in the collection of the pensio and the management of the coloni, but in addition paid considerable rents to the Church for their leases ${ }^{2}$. The only payment, so far as is known, which was made to them by the coloni was that consisting of the excepta, and this, as its name shows, was a small deduction made from the amount of the pensio, and was probably intended as a remuneration for the trouble involved in the collection of the latter. Moreover, it is obvious, from the example given above in the case of Gentio, that these payments in kind were not of great value and could certainly not have been worth paying rent for, since Gregory allowed him to receive them as a present, so that, if they had constituted the sole return for the rent usually

1 Except that a modius of 18 sextarii was allowed in place of one of 16. Greg. Reg. I. 42.

2 See the large rent of Iog solidi and 100 megarici of wine paid by the Consul Theodore for the island of Capri. Jaffé, Reg. 2216. 
paid, Gregory would have been making him a present not only of the excepta but also of the rent paid for them. It is clear, therefore, that the conductors must have profited in some other way, and profited considerably, as we know there was great competition to secure leases of church lands.

It is probable that on each estate, in addition to the holdings of the coloni ${ }^{1}$, there was a home farm attached to the villa of the conductor and usually cultivated by slave labour, and that it was in respect of this that the conductor paid rent. But if this were all the advantage a conductor obtained from his estate it would have been natural for him in each case to have taken only a small farm, which could be easily cultivated by the labour of his own slaves, instead of a large estate with all the care and trouble which the oversight of the coloni on it entailed. It seems to me possible, however, that in the case of private owners the landlord received from his coloni not only their pensio; but also labour services, since it had been one of the objects of the institution of the colonate to obtain better cultivation of the land and a substitute for slave labour ${ }^{2}$. If this supposition were

1 That each colonus possessed a customary right to cultivate a piece of land as his own holding is proved by Gregory's order that a certain colonus should hold his plot of land for life free of pensio. Greg. Reg. IX. 37.

${ }_{2}^{2}$ It is only fair to mention that Savigny states that there is no evidence of this; he says "davon, dass sie (the coloni) auch Dienste auf dem herrschaftlichen Gute geleistet hätten findet sich keine Erwähnung" (Der römische Colonat, p. 37). But the very fact that he goes out of his way to make this statement shows that he must have considered it not improbable that such services were rendered. 
true, it would be not unreasonable to suppose that on the church lands, as the pensio was paid to the Church, the labour services were rendered to the conductor, who was the actual tenant in possession of the land and occupied a position similar to that of a private owner on his own estate.

The result would be as follows: on each estate there would be, in addition to the holdings of the coloni, a large farm, or demesne, attached to the dwelling of the conductor and worked by him for his own profit. The larger part of the work of this farm would be performed by slaves, but the coloni would have to give assistance at such times as harvest, and perhaps on one day a week throughout the year.

This theory will be found to fit in at once with all the facts as we know them. The eagerness to obtain leases of church land is explained by the fact that the conductors were thus enabled to work larger farms than they otherwise could have done and that they were sure of a constant supply of labour. The right possessed by the conductors to benefit by the labour of the coloni explains the quasi-servile position in which the coloni stood in relation to the conductors and the payments made to these latter by the coloni on the occasion of the marriage of a daughter ${ }^{1}$; while the excepta at once fall into their place as being merely an allowance to compensate for the trouble involved in the collection of the pensio. This theory,

1 The semi-servile position of the coloni with regard to the conductors is shown by the instructions sent to the conductors in Gaul to keep their coloni in order. Greg. Reg. v. 3r. 
if correct, shows a state of affairs strikingly similar to that which obtained under the later feudalism, which in Italy, at any rate, developed gradually without any sudden introduction from the north ${ }^{\mathbf{1}}$.

In the case of lands which were not leased out but were retained by the Church in its own hands, and were managed by so-called conductors who were either coloni or slaves, the considerations set out above would not apply. In such cases it may be presumed that the church authorities were content with the pensio, or if labour services were rendered they would be employed on a home farm, managed by the bailiff conductor, the profits of which were paid into the church treasury.

So far the only coloni mentioned have been agricultural labourers, but some appear to have been artisans, and these, with the permission of the church authorities, might work for pay outside their massa. There is on record ${ }^{2}$ the case of a certain Alexander Frigiscus, a colonus, who worked for three years on a house built by the rector Cyprian at Syracuse. Thinking that he had not received his proper wages he went to Rome to lay his complaint before Gregory, who ordered Scholasticus, a defensor, to examine the case, and, if the work done was not covered by the $\mathrm{I}_{4}$ solidi 2 tremisses ${ }^{3}$ which Alexander had already received, to

1 Another resemblance between the position of the medieval villeins and the coloni may be noted in the almost legal force of the "custom of the estate."

2 Gteg. Reg. IX. 43.

3 This amount seems absurdly small, but the purchasing value of the solidus seems to have been high (intrinsically it only equals c. 12 shillings). There is a gift to a colonus of 
make up his wages to the standard fixed by law. In a letter from Pope Gelasius ${ }^{1}$ to the rector of Picenum the Pope ordered the latter to give or lend to the imperial linen manufactories (gynecaea) such slaves or coloni as might be useful there; but he was to remember that "non eiusdem aestimationis est artifex et ministerialis puer contra rusticum vel colonum" and to take care that he did not give men who were useful in the fields and receive useless persons in their place.

It might be thought, from the numerous payments which had to be made by the coloni and the oppor-. tunities of extortion to which they were subject, that their condition was one of unmitigated misery and squalor. In many cases, no doubt, they led very hard lives, but care must be taken not to exaggerate the disabilities under which they suffered. Gregory's Dialogues, which throw a wonderfully vivid light on the conditions of the time, show that there was often a considerable amount of comfort enjoyed by the lower classes ${ }^{2}$ and a pleasing story is related by him of a feast given by a colonws, the father of S. Honoratus, to his friends and relations. The banquet was all of flesh, showing that at any rate meat was plentiful, and though water seems to have been the chief beverage there was a slave to wait on the guests ${ }^{3}$.

2 tremisses, and examples of rents of 3 siliquae, and even of I tremissis. Greg. Reg. IV. 28, IX. 194, II. 3.

1 Jaffe, Reg. 956.

2 The more important villeins in medieval times were often persons of considerable wealth and local importance.

3 Greg. Dialogues, lib. I. c. I. 
In another letter Gregory refers to a colonus who was famous for his hospitality and who had travelled to Rome to see him; that he might continue to practise this virtue Gregory ordered the plot of land he held to be given to him for life, free of pensio ${ }^{1}$. The Church also was open to the colonus and ordination afforded a means of escaping from the toils of agricultural life. But the status of the colonus still adhered to him in the $\mathrm{Church}^{2}$, and it was only the episcopate which brought with it full freedom ${ }^{3}$.

In addition to the coloni there were living on the patrimony a considerable number of slaves. These slaves consisted of two classes, those living on the land in peasant communities, and those who were employed as artisans and personal servants, and this latter class seems to have comprised the larger number. Christianity had undoubtedly done much to alleviate the condition of slaves, and, as will be shown later, afforded them many kinds of protection; it had overthrown the Aristotelian view that some men were by nature slaves, and recognised all men as free and equal in the sight of God ${ }^{5}$-Nevertheless Christianity found the institution existing, and, though it did

1 Greg. Reg. IX. 37.

2 Previous to Justinian a colonus could not be ordained without his lord's consent. Justinian however made the lord's consent unnecessary and allowed a colonus to be ordained if he remained in his massa of origin and paid his share of the tributum and capitatio. Just. Novel. cxxIIl. c. I7.

3 Just. Novel. cxxirr. c. 4. Post ordinationem vero servili et inscriptitia fortuna episcopos liberos esse praecipimus.

4 Greg. Reg. IV. 12.

- Ibid. Homines quos ab initio natura liberos protulit et jus gentium jugo substituit servitutis. 
much to alleviate it, did not attempt to abolish it. In view of this there is nothing inconsistent in the fact that the Church, like any other owner, possessed slaves and at times insisted on preserving the legal rights which it had in them. The Roman law still regarded the slave in exactly the same light as in classical times, as being a mere chattel and the absolute property of his owner. He could possess no property of his own; his various small savings, his "peculium," only belonged to him by custom, and any gifts or legacies left to him belonged to his master. That the Church maintained its rights as owner to the peculia of its slaves is shown by the fact that in the deed of manumission of two church slaves, Thomas and Montana, which is referred to below, Gregory expressly stated that he gave them (donamus) the legacies left to them by the will of a certain priest, but in the case of Thomas on condition that if he died without issue the legacy should revert to the $\mathrm{Church}^{\mathbf{1}}$. A male slave could not marry a free woman, and a marriage between a free man and slave woman was not recognised as being anything but concubinage; in one of Gregory's letters mention is made of a cleric of the church of Naples who had tried to get rid of his wife on the pretext that she was a slave, but since the woman had been proved to be free, the Pope ordered the bishop of Naples to compel the husband to live with her ${ }^{2}$. Household slaves and

1 Greg. Reg. VI. 12.

2 Ibid. vil. I. The husband must have been in minor orders only. 
personal servants would of course travel about in attendance on their master, but in the case of the peasant slaves dwelling on the land, residence in their massa was enforced, in the same way as with the coloni; and Pelagius I instructed Melleus ${ }^{1}$ the subdeacon "ut Clerentium ex ancilla ecclesiae procreatum qui ad declinandam servitutem debitum curialis nomen sibi audeat usurpare...in massam ecclesiae festinet revocare." This is but one of the many extant letters in which reference is made to the flight of slaves from their masters or their massae of origin, and the frequency of these references, and numerous attempts made by the fugitives to claim some other status, show that the position of the slave could still be a by no means enviable one. It is remarkable in view of the claim of Clerentius to be a curial that in a letter of Cassidorus reference is made to ecclesiastics who had claimed certain curials as their slaves ${ }^{2}$. S. Gregory, though he favoured the manumission of slaves and did much to insist on the duty of kindness towards them, was always careful to repress any unauthorised attempts on their part to escape from their position. He gave strict orders to the rector of Calabria to watch for a fugitive slave, a member of the guild of bakers (de arte pistorica), who belonged to Gregory's brother, and to arrest him, if possible, together with his wife and children, and send them all to Rome in custody ${ }^{3}$. In another case he ordered the rector of Campania to send back to Sicily a state
1 Jaffé, Reg. I023. Migne, 69, p. 418.
2 Cass. Var. II. I8. 200.
S. P. 
slave who had, by misrepresentations, induced a sailor to take him to Campania and had then entered a monastery there ${ }^{1}$. In several other letters he ordered various rectors to assist abbots and monks in regaining their fugitive slaves ${ }^{2}$. There are two letters of Gregory in which the Pope orders the purchase of slaves for the Church, though it is to be observed that in both these cases the objects were charitable and praiseworthy. In the first, Candidus the rector of $\mathrm{Gaul}^{3}$ was instructed to purchase English slaves who might be sent to monasteries and instructed in the Christian faith; in the second, the rector of Sardinia was ordered to assist the notary Boniface, who had been sent to that island to purchase slaves for employment in the service of the poor-houses (ptochia) of the Church ${ }^{4}$.

But the Church, as has been stated above, always favoured the emancipation of slaves and regarded it as a distinguished act of Christian piety and one conferring great merit. A law of Constantine enacted that the formal act of manumission should take place in the church and in the presence of the clergy and people ${ }^{5}$. Gregory himself seems to have favoured the manumission of slaves, and there exists a formal deed of manumission granted by him to Thomas and

1 Greg. Reg. IX. I44.

2 Ibid. IX. Io, r91. 3 Ibid. vi. ro.

- Ibid. IX. I23. Et ideo experientia tua omnino ei sollicite concurrat ut et bono pretio et talia (mancipia scil.) debeat comparare ut et quae in ministerio ptochii utilia valeant inveniri.

B Ibid. vi. 12. Manumission was to be "adsistentibus Christianorum antistitibus." Cod. Just. I. I3, also Cod. Theo. IV. $7 . x$. 
Montana, two slaves of the Church ${ }^{1}$, which is worth mentioning in some detail, as Gregory's deeds of manumission seem to have been taken as precedents by subsequent Popes. After reciting that the giving of freedom is an act well pleasing in the sight of God, the instrument states that the two slaves are now made Roman citizens and gives them their "peculium." Montana is to enter a monastery and Thomas is appointed to a position among the notaries of the Church. The manumission is to be irrevocable, and the deed goes on to state that it was dictated to Paterius the notary in the presence of three priests and three deacons, and signed by Gregory himself. The formulae given in Liber Diurnus are almost exactly similar to this; the operative words of these deeds were those conferring the Roman citizenship, "te civem Romanum efficimus"." The taking of orders and admission to a monastery were among the most frequent means of escaping the burdens of slavery. The consent of the owner was of course necessary, and Justinian enacted that if a slave was ordained without his lord's consent the lord might claim him within a year ${ }^{3}$. Slaves who wished to enter a monastery had to undergo a three years' novitiate before admission, and within this period the owner might reclaim them if his permission had not been granted ${ }^{4}$. Both ordination and admission to a

1 Greg. Reg. vi. 12.

2 Cf. Lib. Diurn. 39. Ab omni servili fortuna et conditione liberum te esse censemus civemque Romanum solutum ab omni subjectionis noxa decernimus.

${ }^{3}$ Just. Novel. cxxiIr. 17.

4 Ibid. v. 2. 
monastery conferred freedom on slaves, but if at any future time they lapsed from the clerical life or left their monastery their servile status returned. The attainment of the episcopate alone conferred full freedom on both slaves and coloni.

The Church was careful to insist on the observance of these laws. Thus Pope Gelasius ordered certain slaves, who had been ordained without their owners' consent, to be restored to their masters ${ }^{\mathbf{1}}$, and Gregory was careful to state, in the case of a slave who had become a monk but had then lapsed, that the servile status which he would have escaped if he had remained in his monastery must now be resumed ${ }^{2}$. An oath seems to have been demanded from the candidates for admission to monasteries that there was no legal impediment to their admission ${ }^{3}$. The Church, however, always impressed on owners the merit of granting such permission, and in one case Gregory instructed the rector of Campania to interview Felix, a defensor, the owner of a female slave who wished to enter the conventual life, and to induce him if possible to give his consent. If he would not, the rector was to try to purchase the girl and, if successful, was to send her to a convent ${ }^{4}$ Many

1 Migne, 59, p. I44.

2 Greg. Reg. v. 28 . Ut postquam a monachica conversatione culpae lapsus abripuit jugam dominii quod evadere...permanens poterat recognoscat.

s Ibid. IX. I44. Iurisiurandi interveniente vinculo liberum se, nullique conditioni obnoxium publica voce professus est. Decurions were absolutely forbidden to enter monasteries or to be ordained, and the Emperor Maurice forbade the ordination of soldiers or their reception into monasteries, much to Gregory's wrath. See ibid. Irr. 6r.

4 Ibid. III. 39. 
church slaves entered the Church and in Gregory's words "hastened from servitude in this world that they might become free in the service of God ${ }^{1}$." So great was the rush that there was danger that the Church would be deprived of all its slaves; and the synod held in Rome in the year 595 thought it necessary to pass a decree that all church slaves should be carefully examined as to their lives, and proved in the lay habit, before being allowed to enter monasteries.

The insistence of the Church on the merit of manumission led many persons to confer freedom on their slaves by will, and, in one case ${ }^{2}$, Gregory granted the papal licence to a monk, to confirm by will the freedom he had granted to his slaves before he entered the monastery.

The recognition of Christianity by Constantine led that Emperor to forbid Jews to possess Christian slaves, and this law was re-enacted by Justinian, who forbad any heretic, pagan, or Jew to possess or circumcise Christian slaves and ordered any such slaves to be at once freed ${ }^{3}$. The Church insisted with great vehemence on the observance of this law and Gregory continually urged the various bishops of Italy to insist on its being carried out 4 . The law was extended

1 Greg. Reg. v. $57 a$. Ut ab humana servitute liberi in divino servitio valeant. This seems to refer to coloni as well as slaves, the word "familia" includes both. In the case of the former the consent of the Church would not be necessary but it was necessary in the case of slaves.

2 Ibid. IX 164 .

3 Cod. Just. I. ro. Ne christianum mancipium haereticus vel paganus vel Judaeus habeat vel possideat vel circumcidat.

* Greg. Reg. IV. 9, 2r, IX. 213. See also a letter of Gelasius, Migne, 59, p. 146. 
$[\mathrm{CH}$.

to include the case of Jewish slaves who wished to become Christian, and Gregory rebuked archbishop Januarius of Sardinia for allowing Jewish slaves, who had expressed a desire to be converted and had taken refuge in churches, to be given back to their masters or made to pay for their freedom; Gregory directed that they should be at once freed without being forced to make any payment ${ }^{1}$. Gregory insisted that the law also applied to the case of pagan slaves who wished to become Christians; although the Jews naturally resisted this interpretation ${ }^{2}$. One exception to the law was, however, admitted by the Pope: in the case of slaves living on the land, who might be considered as owing services to the land rather than to the person of their master, the fact that the slaves were Christian and the owner a Jew was not to be regarded as a reason for freeing them; but Gregory insisted that they should be regarded as coloni, and not slaves, and that, if the master should attempt to remove the slaves or employ them as personal servants, the ordinary law should take effect ${ }^{3}$. In a case where Samaritans living at Catane had bought pagan slaves and circumcised them Gregory ordered the bishop to free the slaves immediately, and declared that the masters ought to be punished by the civil courts ${ }^{4}$.

The Church not only encouraged the manumission of slaves but did much to protect them from violent and tyrannical masters. It was quite a common

1 Greg. Reg. IV. 9.

2 Ibid. vi. 29.

3 Ibid. Iv. 2 r.

- Ibid. vi. 3o. The punishment was death by a law of Constantine. See also for Samaritans, viII. 2r. There seem to have been some Samaritans scattered about in the West. 
custom for slaves, who had been cruelly treated by their masters or had committed some slight fault and feared cruel punishment, to take sanctuary before the altar of the Church. Pope Gelasius directed that after the master had entered into a bond with an official of the bishop that he would not take vengeance on his slave, the slave should be handed over and if necessary be compelled to return to his owner ${ }^{1}$. It appears that if the master refused to overlook the fault or had maltreated his slave without reason the latter might be freed. Gregory followed the same procedure as Gelasius in this matter, but he forbade the abuse, which was practised by some of the church officials, of claiming for the Church the slaves who took sanctuary and refusing to give them up to their owners ${ }^{2}$. Gregory also frequently protected freedmen and the children of freedmen from those who threatened their status and unjustly claimed them as slaves. This seems to have been a very common form of intimidation and the church agents were not always as scrupulous as was the Pope ${ }^{3}$. Gregory, moreover, did his best to defend the church slaves from illtreatment by outsiders, and in one case ordered the ecclesiastical "tuitio" to be given to a church slave who had been annoyed by the attacks of a neighbouring landowner ${ }^{4}$.

The popes frequently made gifts of slaves to various

1 Jaffé, Reg. 7II. Migne, 59, p. I52. Metuentes famuli dominos si ad ecclesiae septa confugerint intercessionem debent quaerere non latebras.

2 Greg. Reg. I. 39 a. See also for slaves taking sanctuary, III. I. 
persons ${ }^{1}$ and it is a striking fact that in one formula for the gift of a slave given in Liber Diurnus provision is made that on the donee's death the slave shall be freed ${ }^{2}$; this does not seem to have been the practice in Gregory's time, but his gifts of slaves were always made to personal friends of whose justice and kindness he had no doubt. In a letter to his friend Narses, an official of the court at Constantinople, he expressed the hope that through service with Narses the slave whom he was sending might learn the way to the heavenly freedom ${ }^{3}$.

There can be little doubt that the slaves of the Church were in a much better position than those of private owners; they were treated as human beings and not as chattels, and as being, in many respects, the equals of free men ${ }^{4}$; while at the same time they enjoyed a security of position which the slaves of private persons could not hope to attain ${ }^{5}$. Although the Church had not in the seventh century succeeded in abolishing slavery it had already done much to

1 Greg. Reg. IX. 98.

${ }^{2}$ Lib. Diurn. 38. Ideoque ex apostolica auctoritate tibi illum puerum... largimus serviendum... quem in tuo dominio sub tua conditione statuimus esse, ut post tui diem obitus, si bene servierit a jugo servitutis absolvatur, libertate a te munitus.

${ }^{3}$ Greg. Reg. vir. 27. De cuius anima cogitans eum dulcedini vestrae transmisi ut in eius vivat in hac terra servitio per quem ad libertatem caeli valeat pervenire. See also ibid. III. I8, gift of a slave by Gregory to his consiliarius Theodore.

4 E.g. the instructions given by Gregory to Cyprian, rector of Campania, to redeem from the Lombards free men who cannot redeem themselves, slaves whom their masters cannot redeem and slaves of the Church. Reg. vi. 32.

5 It does not seem probable that the Church ever sold its slaves, at least there is no record of any such sale. 
alleviate the condition of the slave and a considerable step forward had been taken towards the final abolition of this horrible institution.

The church officials, conductors, coloni and slaves did not, however, comprise all the inhabitants of the patrimony. In the small towns situated in the various patrimonies, especially in Sicily, there seem to have dwelt a certain number of merchants ${ }^{1}$. Towards these Gregory showed great kindness, especially when they were in money difficulties. In one case he ordered the rector Cyprian to try to persuade the creditors of a Syrian trader, Cosmas by name, to accept a composition and to give Cosmas something wherewith to start again ${ }^{2}$; and in another case, where a Jewish merchant Tamnus had given notes of hand to his creditors, and among them to a defensor Candidus, Gregory ordered Candidus to give up the note of hand which he had kept although the debt had been paid ${ }^{3}$.

Among the inhabitants of the patrimonies there must have been a certain number of artisans. Trade and manufacture had much declined during the fifth and sixth centuries, but some of the guilds of artisans still maintained a lingering existence. There are references in Gregory's Dialogues to builders, to the guild of dyers in Rome, to shoemakers ${ }^{4}$, and, in one of his letters, to the guild of soap boilers in Naples ${ }^{5}$; and the villages of the patrimony cannot have been without some of these necessary elements of society.

1 Cf. Greg. Reg. I. 42. Liberatus negotiator qui se commendavit ecclesiae.

3 Ibid. IX. 40.

5 Greg. Reg. IX. II3.

2 Ibid. III. 55, Iv. 43.

4 Greg. Dialogues, lib. Iv. c. 36 . 
There were also dwelling in S. Italy and Sicily a considerable number of Jews. Some of these were independent landowners with large numbers of coloni on their lands ${ }^{1}$, many were merchants, especially in the slave trade ${ }^{2}$, and in Sicily there were many Jewish coloni settled on the church lands ${ }^{3}$. It may be as well to give here a general outline of Gregory's attitude towards these Jews, both on the patrimony and outside it. In his relations with the Jews, as in all other matters, Gregory was scrupulously just. He was careful to protect them from the untimely zeal of proselytising bishops and from outbreaks of popular intolerance. He rebuked a bishop who had seized a synagogue and consecrated it as a church, and ordered the value of the property to be given to the Jews ${ }^{4}$; he forbade two Gaulish bishops to baptise Jews by force ${ }^{5}$, and he ordered another bishop to admonish a zealous Jewish convert who had entered a synagogue, smashed the furniture, and set up a crucifix and pictures of the Virgin ${ }^{6}$. At the same time he insisted that the Jews should strictly observe the law. He urged Libertinus, the praetor of Sicily, to punish severely a wicked Jew named Nasas who had, apparently in derision, erected an altar to Elias and deceived many Christians "sacrilega seductione?." Gregory, as has been said above, was particularly careful that the law forbidding Jews to possess

1 Greg. Reg. IV. 2 I.

2 Ibid. IX. I04.

3 Ibid. II. 38, v. 7 .

Ibid. Ix. $3^{8}$.

5 Ibid. I. 45 .

- Ibid. Ix. I95. The crucifix and pictures were to be removed.

7 Ibid. III. 37. 
Christian slaves should be strictly enforced; but to Jewish slave dealers who had bought Christian slaves in Gaul he allowed a period of forty days in which to dispose of the slaves to Christian owners before enforcement of the law ${ }^{1}$. Gregory, however, was very desirous of procuring the conversion of Jews by all legitimate means. He ordered the rector Cyprian to promise a remission of one-third of their pensio to such of the Jewish coloni, settled on the Sicilian patrimony, as became Christians, and he observed that even if they were not sincere in their conversion their children at any rate would be sincere Christians $^{2}$. This offer, as might be expected, was attended with considerable success, and such multitudes applied for baptism that Gregory had to give special directions to the local bishops as to how to deal with the matter and ordered that baptismal robes should be provided free of charge for such as could not afford to buy them ${ }^{3}$.

In Sardinia ${ }^{4}$, Corsica, and even in Sicily ${ }^{5}$, a considerable number of the more ignorant coloni and slaves seem to have still been pagan. Gregory felt that this was indeed a reproach to the Church. In Sardinia in particular he made great efforts, and sent thither a special mission which, helped by the cooperation of the local bishops and civil authorities,

1 Greg. Reg. Ix. ro4.

2 Ibid. v. 7. Similar orders had previously been given to Peter the sub-deacon in II. 38 .

3 Ibid. virr. 23. See also gifts and protection given to Jewish converts, IV. 3I, I. 69 .

4 Ibid. IV. 23, XI. I2, VIII. I.

5 Ibid. III. 59. 
was very successful ${ }^{1}$. In Sicily there still remained not only pagans, but Manichees and other heretics ${ }^{2}$; in their case Gregory seems to have sanctioned persecution. Sorcerers and magicians he was determined to suppress, these he ordered to be sought out and punished $^{3}$. But it would. be wrong to conclude from these facts that the vast majority of the rural population were anything but Christians, and Christians too of a type who could withstand persecution; in proof of this we may quote Gregory's Dialogues which contain an account, in all probability true, of the butchery by the Lombards of forty Christian coloni who refused to join in heathen rites 4

1 Greg. Reg. XI. I2. Its success may have been due in some degree to the somewhat forcible methods employed. See $i b i d$. IV. 25 .

2 Ibid. v. 7 .

3 Ibid. xI. 33. The punishment of sorcery seems to have been death by burning. See Greg. Dialogues, lib. 1. c. 4. "This wretch (Basilius, a sorcerer) not long after in this city of Rome, through the zeal of good people, for his wickedness was burnt and so ended his life."

${ }^{4}$ See Greg. Dialogues, lib. III. c. 27. "For about I5 years since, as they report who might very well have been present, 40 husbandmen of the country were taken prisoners by the Lombards, whom they would needs have enforced to eat of that which was sacrificed to idols: but when they utterly refused to do so, or so much as once to touch that wicked meat, then they threatened to kill them unless they would eat it: but they, loving more eternal than transitory life, continued constant and so they were all slain." See also the next chapter: "of a great number of prisoners that were slain because they would not adore a goat's head." On the other hand it is probable that the tree worshippers at Terracina mentioned by Gregory in vilI. I9 had adopted this superstition from the Lombards. 


\section{CHAPTER IV}

\section{RELATIONS WITH THE STATE}

\section{A DISCUSSION of the general relations of the}

1 Church to the State during the fifth and sixth centuries is of great importance as showing that gradual growth in power and independence which eventually led to the medieval conception of the Church as humanity organised on its spiritual side, and in this aspect equal to, independent of, and finally superior to the temporal organisation of the world, that is to the State. But it is impossible here to consider the question in its general form or even in the more limited aspect which deals with the growing independence of the Papacy and the establishment of its temporal power. We must confine ourselves to the discussion of those relations between the two powers which arose out of the existence of the patrimony.

Even here will be found many points of interest and importance which illustrate forcibly the continued increase in strength of the Church and hierarchy, the declining power of the Empire, and the gradual transition to medieval conditions. On the various points of contact between the Church and the imperial officials, which arose out of the possession of landed property by the Church, S. Gregory's letters are almost the only source of information, and I shall therefore merely mention the points to which reference is made in those letters without attempting to 
deal in any general manner with the relations between the two powers.

The attitude of the officials of the patrimony to the imperial officers seems to have been, as a rule, one of watchful independence. It was important for the Church to conciliate the state officials and to retain their good-will whenever possible, but at the same time to avoid a servile attitude or one which was likely to invite attack. This policy is well illustrated by the directions given by Gregory to Peter the subdeacon soon after his appointment as rector in Sicily ${ }^{1}$. Peter is directed to behave, not in an arrogant manner but in such a way that the officials and the lay nobles may love him for his humility and not hate him for his pride; at the same time he is to resist them when they act unjustly. It was the usual custom to ensure this good-will by making various gifts to imperial officials, and Gregory in another letter instructed Peter not to omit the usual presents to the members of the Praetor's officium, and to give in addition small presents to the recruiting officers (scribones) "quatenus eos sibi placabiles reddant ${ }^{2}$." The popes endeavoured to obtain the good-will of the more important imperial officials beforehand, and it was Gregory's practice to write to the Praetor of Sicily, to the Exarchs, and to the Praetorian Prefects, on their appointment, congratulating them, and at the

1 Greg. Reg. I. 39 a. Laici autem nobiles vel vir gloriosus praetor pro humilitate te diligant non pro superbia perhorrescant.

2 Ibid.II. 38. Sed et officio praetoris priusquam venias aliquid secundum consuetudinem antiquam tribue per manus tamen illius quem dimittis ut ei gratiam eorum concilies. 
same time urging them not to infringe the rights of the Church ${ }^{1}$. The officials of the imperial patrimony seem to have been especially liable, as was perhaps natural, to assume an unfriendly attitude towards the papal patrimony, and on the appointment of a certain Talitanus as "comes rerum privatarum" (or perhaps "comes sacrarum largitionum") in Sicily, Gregory wrote a special letter to him, commending the church patrimony to his protection, and asking that he would not allow his officials to attack the property of the Church, a habit which it seems was not unusual ${ }^{2}$. The great object of the papal policy was to have as little as possible to do with the imperial officials, and, where relations could not be avoided, to maintain a perfectly correct attitude, not even shrinking, when it was expedient, from sacrificing its own point of view to that of the other side ${ }^{3}$. The subordinate officials do not seem to have been always as discreet as the Pope. On one occasion certain ecclesiastical persons in Sicily refused to give account to the State of their property for purposes of taxation; Zittanus the magister militum of Sicily thereupon complained to Gregory and the latter replied that the news had much grieved him and that he had written to Fantinus the rector to compel them to account ${ }^{4}$.

1 Greg. Reg. I. 2, IX. 239.

2 Ibid. Ix. 239. Que ne forte, fieri ut assolet, occasione inventa homines publici quandam vellent inferri molestiam hoc magnitudinis vestrae bonitas fieri non permittat.

3 See the concessions made to Cyridanus in IX. I I 5 .

- Greg. Reg. x. ro. Epistolas vestras me indico suscepisse in quibus dicitis quod quaedam religiosa loca responsum iuri publico de rebus ei competentibus reddere contemnant. 
It will perhaps be well to examine more in detail the various points at which the officials of the patrimony and the state officials came into contact. In the first place, as has been mentioned in the previous ehapter, the church estates, like those of any other owner, were liable for the "tributum," the land-tax. This tax was a very heavy burden. We know from Gregory's letters that so much as 507 solidi could be collected by one tax-collector for one of the three yearly instalments. In fact it became so oppressive after Gregory's pontificate that not only private owners but the Church itself was sometimes unable to pay. Thus we read in Liber Pontificalis that John the deacon (afterwards Pope John V), who had been sent by Pope Agatho (678-68I) as a delegate to the Sixth General.Council, returned bringing with him a remission of taxes-" necnon et alias iussiones relevans annonocapita patrimoniorum Siciliae et Calabriae non parva, sed et coemptum frumenti similiter vel alia diversa quae Ecclesia Romana annue minime exurgebat persolvere $1 . "$ A very similar entry occurs under the pontificate of Pope Conon, showing that, as a result of the non-payment of the tax, the coloni and slaves of the patrimony had been seized as pledges ${ }^{2}$.

The burden of the "coemptum frumenti" or "coemptio," referred to as being lightened by ConstantinePogonatus, was another imperial privilege from which

1 Liber Pontificalis, ed. Duchesne, vol. 1. p. 366.

2 Ibid. p. 369. Itemque et aliam iussionem direxit ut restituantur familia suprascripti patrimonii (Brutii et Lucaniae scil.) quae in pignere a militia detinebantur. 
the coloni suffered. It consisted in the right to make forced purchases of corn and other supplies needed for the service of the State, and resembled the abuse of purveyance, so much complained of by the Commons in England under the fifteenth century and Tudor sovereigns.

The coloni were also liable to the duty of military service. The system was not one of universal conscription but more resembled that of ballot. - The recruiting officers (scribones), went round and selected a sufficient number of recruits who were then compelled to serve ${ }^{1}$. These scribones had a bad reputation, and Gregory instructed Peter the sub-deacon to tell his subordinates to give them small gifts "ut eos sibi placabiles reddant ${ }^{2}$." Probably unless he received a douceur of some kind the scribo would revenge himself by taking an excessive number of recruits from the church lands, thus depriving these of cultivators.

About this time, owing to the Lombard invasion and the unsettled state of the country, castles or forts had been built in most of the important towns, and the dwellers in these places, who seem to have been freemen and probably soldiers, had the duty of defence laid on them ${ }^{3}$. On this account they were freed from most impositions and taxes ${ }^{4}$. We know that the

1 Greg. Reg. Ir. 38. Venientibus scribonibus qui sicut audio illic tyrones colligunt.

2 Ibid.

3 Note the beginnings of what might be called tenure by military service.

${ }_{4}$ Cf. Greg. Reg. IX. 205, where Gregory requests Occilanus the tribune of Otranto not to oppress the rustics on the lands

S. P. 
Church possessed at least one of these "castra," that of Callipolis in Calabria, and its tenants, like those of the State, or of any other owner, were subject to this duty of defence. In one letter Gregory instructed the bishop of Callipolis to see that the "habitatores" of this castrum were not oppressed by illegal exactions, and sent him documents from the Church "scrinium" to prove the privilege of exemption ${ }^{1}$. The tenants who dwelt in these castra were not liable for any "pensio" to the landlord, but paid only a small ground rent called "solaticum " $r$, in the case of the castrum of Scylacaeum, which belonged to a monastery, the tenants for some time refused to pay even this rent and had to be coerced ${ }^{2}$. That the habitatores did not always abserve their duty of residing in the castra is shown by the fact that Gregory had to refuteg Pimerius $^{3}$, the bishop of Amalfi, for non-residence in his see, on the ground that his example had led the habitatores to live outside their castrum, thus leaving the city open to a sudden attack by the enemy ${ }^{4}$.

of the Church with impositions (angariis) since, if he does so, they will desert the land and occasion will be given to the enemy.

1 Greg. Reg. IX. 206.

2 Ibid. vIII. 32. "Habitatantes illic factis libellis solaticum singulis annis expondisse persolvere sed postea contempsisse et ab eadem se praestatione supervacue suspendisse."

3 Ibid. vI. 23.

4 See also ibid. vIII. I9. It may be as well to mention here, before dealing with the corn supply, that though the Church was liable, like private owners, for most of the Imperial taxes, an exception seems to have been made in the case of custom duties; for Gregory in IX. 132 orders Hilary, rector of the African patrimony, to see that a ship sent to the Abbess Adeodata is exempted from all tolls and duties as though it had been the property of the Roman church. "Qua illic 
One of Gregory's letters reveals a striking fact which, taken with what will be said immediately below about the "annonae," illustrates forcibly the weakness of the imperial government on its executive side, and its readiness to employ in executive business

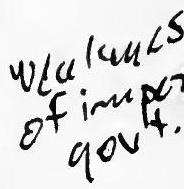
the superior organisation of the Church. Gregory, writing to Anthemius, rector of Campania, states that Benenatus, bishop of Misenum, had been entrusted with public money to build a fort there. Instead of doing so he had spent most of the money himself, and Gregory ordered Anthemius to take from the Bishop what still remained and hand it over to Comitacius, the count of Misenum, to be employed for its original purpose. That the State should employ the Church as its agent in the distribution of the food supply is not astonishing, but that it should be willing to entrust the Church, in preference to its own officials, with the work of constructing military defences argues but little faith in the capacity of these latter.

There was yet another point in which the Church and State came into contact. This was over the $\checkmark$ public corn supply. The imperial grants of "annonae," which had supplied Rome during the palmiest days of the Empire, still continued, and, as before, Sicily was still the chief source of supply. The imperial officials, however, do not seem to have been very active in this matter; in one of his earliest letters Gregory had to warn the praetor Justin that veniente hac tibi auctoritate praecipimus ut ita eam in cunctis tuearis atque ab omni angaria vel onere exuere excusareque festines ac si specialiter nostra sit." 
the supply for the last year had been barely sufficient ${ }^{1}$, and he complains in another letter that there are not enough granaries in the city. Most of this corn seems to have been stored in the public granary, called the "sitonicum," but it appears from a letter of Gregory to a certain Cyridanus who was appointed to the oversight of the corn supply, that some of the corn was stored in the barns (horreae) of the Church and distributed by the defensors ${ }^{2}$. Cyridanus, with the energy of a new-comer, seems to have. suspected peculation on the part of the Church and demanded that all the corn stored in the Church barns should be handed over to the "sitonicum," as well as an amount of corn equivalent to what had already been distributed, and that the defensors should produce their accounts. Gregory acquiesced in these demands but washed his hands of all liability in the matter for the future $^{3}$. But this does not seem to have been an isolated instance; it was apparently the usual practice for the State to entrust the distribution of the annonae to the Church. As early as the time of Cassiodorus the bishop of Milan had been entrusted with the distribution of the public supply of corn during a famine in that city ${ }^{4}$ and Gregory in one letter upbraids John, the newly-appointed Praetorian Prefect of Italy, for having removed from the control of the Church in Naples the distribution of the public annonae in that city ${ }^{5}$; there are several other

1 Greg. Reg. I. 2.

2 Cf. Cass. Var. II. 30 and xIr. 27.

3 Greg. Reg. Ix. II5. Cass. Var. xII. 27.

5 Greg. Reg. x. 8. 
letters of Gregory which refer apparently to the distribution by the Church of the public corn supply in Rome ${ }^{1}$. It is easy to see that an arrangement such as this was bound to produce friction and might be attended with serious results.

But perhaps the matter in which the relations of the two powers were most delicate was in regard to the privileged position of the Church and its officials in litigation and criminal procedure, and this must be touched on though it does not strictly concern the

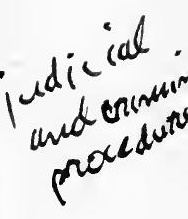
patrimony.

With regard to criminal matters ecclesiastics could not be tried before a lay judge, except possibly fortwo murder or treason; they were subject only to the jurisdiction of the bishop. By Gregory's time this seems to have been fully admitted and did not cause much trouble. In civil matters the practice was that cases in which the plaintiff was an ecclesiastic and the defendant a layman should be tried in the state courts, and those in which a layman was plaintiff and an ecclesiastic defendant, in the church courts ${ }^{2}$. This rule was plainly laid down as early as the time of Gelasius, who in one letter commends to the protection of the Count Zeia two manumitted slaves who had been ordained, and whom, when claimed by the heir of their late master, the archdeacon had wrongfully allowed to appear before a lay tribunal ${ }^{3}$; and the rule was put very clearly by Pelagius I in a letter

1 Greg. Reg. v. 36, Ix. 5 .

2 This privilege had been given to the Roman Church by the famous decree of Theodoric given in Cass. Var. vir. 24.

${ }^{3}$ Jaffé, Reg. 728. 
to the defensor Benegestus ${ }^{1}$. The rule itself, though apparently simple, was just one of those which would lead to innumerable disputes since, as is shown in the letter of Gelasius, referred to above, the Church would constantly claim, as ecclesiastics, persons whom the State would claim still to be laymen, and vice versa, and there seems to have been no machinery in these cases to decide which court was competent to try them ${ }^{2}$. The same rule seems to have applied in cases in which the Church itself and not an individual ecclesiastic, was the plaintiff or defendant. In these cases, however, where, as for instance, a landowner complained of encroachments by the officials of some church, the ecclesiastical court in which the case would be tried would not be that of the bishop of the defendant church, but that of the metropolitan. In the case of Sicily and Southern Italy the metropolitan was the Pope and the conduct of the case was as a rule delegated to the rector of the patrimony in which the defendant church was situated". Gregory often associated some lay noble with the rector in the trial of these cases ${ }^{4}$. It would seem that, when the Church of Rome itself, and not individual

1 Jaffé, Reg. 964. Pelagius Benegesto. Experientiae tuae mandamus ut in causis in quibus quaelibet ecclesiastici officii persona loco petitoris existit quemquam laicum pulsatura apud suae provinciae judicem suas proponere actiones non deferat. In iis vero negotiis in quibus eccelsiastici officii persona pulsatur totius submoto pulsationis obstaculo ad episcopi vel presbyterorum in loco ubi quaestio vertitur constitutorum occurrat indifferenter examen. Mansi, Concil. Ix. 908.

2 Cases between two clerics were of course tried before the bishop.

${ }^{3}$ Greg. Reg. Ix. 32.

4 Ibid. IX. II9. 
members of it, was a party to litigation, the cases were tried in the civil courts, whether the Church were plaintiff or defendant; this was probably due to the fact that, there being no higher ecclesiastical court to hear cases in which the Church was defendant, the civil court represented the supreme jurisdiction of the Emperor. Gregory did not wish the Church to be mixed up in litigation ${ }^{1}$; he says in on sase, referring to a certain Florianus, who seems to have had a claim for a loan of some kind against the Church, "Stephanus chartularius dicitur imminere ut eam praedictus Florianus in publico transferat et grave est nobis cum publico litigare. Unde recesse nobis est aliquid cedere ut possimus eanden causam ad compositionem perducere ${ }^{2}$."

It was not, however, only in cases in which the RomanChurch was concerned that Gregory favoured compronise; he seems to have disliked altogether the uncertanties, expenses and delays of the law, and was constanly instructing the rectors to urge contending parties to choose arbitrators or make a compromise rather than enter into litigation ${ }^{3}$.

It wil be seen from what has been said that the imperial officials had plenty of opportunities of

1 See Grg. Reg. I. 42, where he promises concessions to a certain Alexander if he will finish his suit against the church agents. Se also x. 4, where Gregory ordered the rector to expel fromSicily, within five days, the bishop of Capua who was mixed up in litigation there.

${ }^{2}$ Ibid. Ir. 3. I am not quite clear as to whether Florian was threatining to assign his claim to the State or merely to bring the natter to a public trial; I presume that "in publico transferre' means the latter.

${ }^{3}$ Cf. ibic. III. 57. 
practising extortion and oppression, and that of these they availed themselves to the full, though the Church seems to have suffered less than private individuals. The tales of the oppressions which these latter suffered seem almost incredible; we read that Stephen the chartulary (mentioned above) went about in Sicily affixing "tituli" to the lands of private persons without any shadow of right ${ }^{1}$; that the extortions of the officials in Sardinia and Corsica were so grea: that the unfortunate provincials had to sell their children into slavery in order to pay the taxes, and 1 ed in hundreds to the Lombards rather than live under the Empire $^{2}$. The state of affairs in Sardinia fan be judged by the fact that an official there, when rebuked by a bishop for having continued to demand from the coloni, after they had become Christian, a payment which they had previously made or permission to practise heathen rites, replied that having paid a large sum for his office, he had to reccup himself somehow ${ }^{3}$. In Italy Gregory complained of the Exarch Romanus himself, that it would be preferable to live under the sword of the Lombards raher than suffer from his exactions. The one brightspot was Africa, where the Exarch Gennadius and he Prae-

1 Greg. Reg. v. 38. In Sicilia autem Insula Stephanus quidam marinarum chartularius tanta praeiudici tantasque oppressiones operari dicitur invadendo loca singulrum atque sine dictione causarum per possessiones ac donos titulos ponendo ut, si velim, acta eius singula, quae ad ne pervenerunt, dicere, magno volumine haec explere non posim.

2 Ibid. Unde fit ut derelicta pia republica possessores eiusdem insulae ad nefandissimam Langobardonm gentem cogantur effugere.

3 Ibid. v. 38 . 
torian Prefect Innocent seem to have been energetic and upright men; they were both on very good terms with Gregory, who frequently thanked them for the attention they gave to the patrimony of the Roman Church in Africa, Gennadius having even taken the trouble to settle on the church estates, which had been denuded of cultivators during the wars, the "datitii," or barbarians who had commended themselves to the protection of the Empire ${ }^{1}$.

But though the extortions and rapacity of the officials moved Gregory to wrath, and though he did his best, by representations to the Emperor, to protect the unfortunate provincials from their ravages, he bore no ill-will against them personally, and when justice overtook some of them in the shape of an official enquiry into their actions and accounts, presided over by the ex-consul Leontius, he did his best to see that the church protection, to which some of them had obtained a right by taking sanctuary, was not denied them ${ }^{2}$, and he sharply upbraided Leontius for having illegally scourged a Roman citizen, the ex-praetor Libertinus, finely remarking that the difference between a Roman Emperor and a barbarian king was that one was a ruler over freemen, the other over slaves ${ }^{3}$. To the unfortunate provincials this difference cannot have been very striking.

1 Greg. Reg. I. 73, X. I6.

2 Ibid. IX. 4. The patrocinium of the Church however was not to be given except by Gregory's special order to those implicated "in furtis publicis," IX. 79.

3 Ibid. xI. 4. Hoc enim inter reges gentium et imperatorem Romanorum distat quia reges gentium domini servorum sunt, imperator vero Romanorum dominus liberorum. 
As a matter of fact the officials cannot be altogether blamed for their misdeeds. The imperial ssystem of administration at that period much resembled that of Turkey at the present day; the officials had to pay large sums to obtain their posts ${ }^{1}$, their salaries,were small and generally in arrears ${ }^{2}$, and the only way in which they could make a living was by oppression. The imperial system was rotten to the core, andit can have been a matter of but small regret when it was replaced over the greater part of Italy by the more barbaric, but certainly not more cruel or extortionate, government of the Lombards, or by the clerical kingdom of the Church; and when at last a new emperor arose in Rome, in the person of the great Charles, Italy enjoyed for a few brief years a period of peace and prosperity such as she had not known for centuries.

1 Greg. Reg. xr. 4, v. 38.

2 Gregory did his best to remedy this abuse also, and when the officials of the palace at Rome sent a deputation to Leontius to urge payment of their arrears of salary, Gregory ordered Romanus the defensor to give the deputation every assistance, $\mathrm{IX}$. I06. 


\section{CHAPTER V}

\section{THE COLLECTION OF THE REVENUE}

THE general financial system of the patrimony $I$ and the method by which the revenue was collected have already been touched on, but it may be worth while to spend a short time in discussing these matters in more detail.

The main source of revenue, as has been stated in previous chapters, was the payment made by the coloni to the Church and known as the pensio, and to this must be added the sums paid as rent by such conductors as held lands on lease. The pensio seems always to have been paid by the coloni to the conductors in the first place, and to have been then accounted for by these latter to the notaries of the rector. The conductors probably deducted such amounts as were necessary for the repair of the farm buildings or similar expenses from the sum total of the pensio, and handed over only the net balance to the notaries. The conductors were, it seems, made to account fairly strictly, but in spite of this they sometimes got into debt; thus Pope Gelasius speaks of the conductor Ampliatus (a conductor of the bailiff class) who was "ita rationibus a multis temporibus implicatum ut...donec raticinia cuncta deduceret modis omnibus obnoxius haberetur ${ }^{\mathbf{1}}$." The tenant

1 Jaffe, Reg. 738. Migne, 59, p. I47. That a strict account would be demanded is shown by the end of the letter. "Ac si eidem quidquam humanitatis forte contigerit quia grandaevus 
conductors probably paid the rents, in respect of their land, at the same time as they accounted for the pensio. In Gregory's time the conductors seem, without exception, to have made their payments to the rector or to his officials. Some rectors seem to have insisted on receiving the rents in person, but Gregory discouraged this and in one case told John the bishop of Syracuse ${ }^{1}$, who had been acting as rector in the absence of the defensor Romanus, not to insist on the rents or pensio being paid either at Syracuse or in the massa of Gela, as they might be paid anywhere. When the conductors had paid their rent and the pensiones of their coloni, and their accounts had been examined and found satisfactory, a receipt signed by the rector was given to them.

It seems however that in the time of Gelasius some conductors made their payments directly into the Church treasury, and not to the rector of their patrimony, as we possess two receipts given by Gelasius himself to two conductors. One of these receipts may be quoted as they are probably in the same form as those which were given to the conductors by the rector when the payments were made to him. It runs as follows: "Gelasius Vincomalo. Constat intulisse te rationibus ecclesiae ex praestatione fundi quem conductionis titulo tenes de fructibus anni consulatus Asterii et Praesidii virorum clarissimorum (v.v. c.c.)

esse memoratur mox eius sine dilatione substantiam unanimitas tua filiis eius...sub fideli descriptione contrudat donec temporibus universis quibus hoc patrimonium gubernasse cognoscitur partes dominicas cogatur reddere indemnes."

1 Greg. Reg. IX. 236. 
de indictione tertia solidos numero xxx. Notavi die v. Kal Aug. " " It is hard to say why in these cases the payments were made directly to the church treasury; possibly in the time of Gelasius the fiscal system of the Church was not so elaborately organised as it was later, and tenant conductors (note the words "quem conductionis titulo tenes," which imply a locatio), who were then not very numerous, paid directly into the treasury.

The payments made by the conductors were entered in the account books of the patrimony (libri rationum) by the notaries. The outgoings were also entered, on the debit side. These were very numerous and comprised the salaries of the church officials, sums necessary for the repair of buildings, grants made to monasteries and churches, the sums expended in the purchase of corn and supplies to be sent to Rome, and lastly the numerous benefactions and grants made by special order of the Pope; the orders concerning these latter, as they were extraordinary payments, generally contained a clause instructing the rector to enter them in his accounts ${ }^{2}$. In Gregory's time the custom was for the rectors to send in their accounts, together with the net balance of the revenue, to the church treasury at Rome at the end of every year of the indiction, and Gregory seems to have made it usual, in the case of the patrimonies

1 Mansi, virI. I42, n. 2. Jaffé, Reg. 667, see also 666, a similar receipt by Gelasius to the agents (or perhaps representatives, "actores") of a certain Urbicus.

2 E.g. Greg. Reg. I. 54. Quae tuis postmodum possint rationibus imputari. 
near Rome, for the rectors themselves to bring both accounts and money $\mathbf{1}$.

Before Gregory's time it seems that the income was not paid in regularly by the rectors; thus Pelagius writing to Melleus the sub-deacon ${ }^{2}$ states that "notariorum sedis nostri insinuatione didicimus mullius indictionis a tempore quo tibi primum ecclesiae patrimonium constat esse commissum usque hactenus ratiocinia sunt decisa et ea sint necessario dispungenda ut quid ecclesiasticis utilitatibus debeatur vel quid a quoquam usurpatum sit fideli inspectione cognoscere valeamus"; and in another case he gives a receipt to a rector for the income of four indictions which does not seem to have been paid in regularly ${ }^{3}$. The rectors' accounts do not always seem to have been very satisfactory, and we possess an amusing, though rather obscure, letter from Pelagius I to Dulcitius the defensor ${ }^{4}$ in which the Pope complains that the latter has sent in accounts "nescio quas Graecorum more fucatas" and that, although Dulcitius has been buying houses and "tibi hinc et inde accrescant praedia," the revenues do not seem to increase ("tu nobis de pensionibus angustias generas"); finally he hints that the rector has been practising a little peculation ${ }^{5}$. It seems indeed that

${ }^{1}$ See Greg. Reg. II. 38. Rationes omnes pariter deporta, and IX. 84 .

2 Jaffé, Reg. 957. Migne, 69, p. 4I7.

3 Jaffé, Reg. 95I. Migne, 69, p. 4 I 7 .

- Jaffé, Reg. 949. Migne, 69, p. 418. Mansi, Ix. 737.

5 Non tibi sufficit quod te a notariis et aliis diversis officiis ne commoda exigeris vix te liberare potuimus ut ad summam acriviam quod non vidimus neque accipimus te implesse steteris. The language is obscure but it obviously shows 
the rectors were not always strictly honest and that their 'accounts would not' always bear inspection; thus for example Pelagius ordered a fraudulent rector to be removed from his patrimony, and the money he had made away with to be recovered if possible ${ }^{\mathbf{1}}$; and Gregory forgave to the sons of Urbicus the defensor, rector of Sabina and Carseolum, the large sum which their father owed to the Church at his death ${ }^{2}$; while he had great difficulty in persuading bishop Malchus, the rector of Dalmatia, to come to Rome and present his accounts. The bishop delayed a long time in Sicily and when finally he came it was found that he had been guilty of misappropriation ${ }^{3}$.

According to Zaccaria the revenues from the patrimony were always entered in money, though he seems to think that some were paid in kind; but payment in kind does not seem very probable, and indeed we know that the pensio was as a rule paid in money" There is, it is true, in Liber Diurnus a formula of receipt in which the rector is credited with having paid in not only a certain amount of money, but also a certain number of oxen, horses, cows and pigs $^{5}$; it

that Dulcitius wished to be credited with a larger sum than he had paid in.
1 Jaffé, Reg. I025.
2 Greg. Reg. III. 2 I.

3 Ibid. II. 22, III. 22, v. 6. He very unfortunately died the day after the examination; this gave rise to the rumour that Gregory had had him put to death.

4 See account of the payment of the pensio given in Chap. III. Cf. Greg. Reg. I. 42.

5 Lib. Diurn. 103. Pro qua tradidisti nobis de suprascripto patrimonio, in auro scilicet solidos $x$, boves numero paria $x$, caballos $x$ vaccas $x$ porcos iuxta, accepturi tui tenorem de quibus inlatis nobis praesentatis hac te heredesque tuos plenaria securitate duximus muniendum. 
is probable however that these were not considered as part of the revenue but formed part of the supplies which, as was the case with the corn in Sicily, the rectors of the various patrimonies purchased for the support of the poor in Rome.

When the rectors arrived in Rome their accounts were first examined by the treasury officials and the money was then paid to the treasurer (arcarius) ${ }^{1}$ of the Church and entered in the treasury accounts. If all was in order a receipt (securitas) was then given to the rector. This securitas followed the form laid down by Valentinian and Theodosius in their codes, and when given it could not be called in question. This irrevocability was generally expressed in the receipt itself, as for example in that given to Melleus by Pope Pelagius, which concludes with the words "et tu vel heredes tui in futuro tempore securitate plenaria communiti nullas possitis inquietudines sustinere ${ }^{2}$." I quote the following receipt given by Pelagius to Julian, bishop of Cingulum and rector of Picenum, as a good example of these receipts in general. "Pelagius Juliano episcopo Cingulano. Constat dilectionem tuam intulisse rationibus ecclesiae ex praestatione massarum sive fundorum per Picenum ultra XI positorum quod curae commissum est de indictione viI filio nostro Anastasio argentario et arcario ecclesiae nostrae auri solidos D Notavi die III Kal. Mai. post consulatum Basilii vir. $\mathrm{cl}^{3}$."

1 Jaffé, Reg. 953. See also Zaccaria, op. cit. p. 182.

2 Jaffé, Reg. 957. Migne, 69, p. 417.

3 Jaffé, Reg. 953. Migne, 69, p. 4I7. 
We may note here that this thoroughness of organisation did not extend merely to the collection of the revenue; in everything that concerned money matters the same care of detail was shown. When property was left to the Church it was at once taken charge of by the defensors, who made a careful inventory (notitia) of all the items, and took receipts (desuscepta) from those into whose keeping it was temporarily delivered ${ }^{\mathbf{1}}$; and in the case of large sums of money ordered to be expended on general objects, such as the redemption of captives, a careful record was kept of the expenditure and of the names of those in whose interest it was expended ${ }^{2}$.

In one case the excellence of the church fiscal system enabled it to perform one of the functions of a modern bank. Gregory, in one of his letters to John, bishop of Syracuse, who was acting as rector in the absence of the defensor Romanus, informed him that a certain benevolent person Cethegus and his wife Flora wished to send ten pounds of gold (720 solidi) to Basilius, bishop of Capua, who had been driven from his see by the Lombards and had taken refuge in Sicily. They had paid this sum to the church treasurer, Boniface, in Rome, and Gregory authorised John to pay out ten pounds to Basilius from the revenues of the patrimony in Sicily. Gregory's letter thus fulfilled the purpose of a modern bill of exchange ${ }^{3}$.

1 See Greg. Reg. Ix. I12, 94.

2 Ibid. vr. 32. See also the instructions given to Pantaleo in xIII. 37 to draw up a list of the coloni benefiting by his distributions, and see also for "desuscepta," IX. 19. 74 .

3 Ibid. 1X. 72 .

S. P. 


\section{CHAPTER VI}

\section{THE EXPENDITURE OF THE INCOME}

THE total income from the patrimonies must have 1 reached a vast sum, and to the great credit of the Church this was expended almost entirely on religious and charitable objects. The view that the wealth of the Church was a fund held in trust for the poor is found expressed from the very earliest times, and was continually reasserted by successive generations of popes; and the strength of the feeling is well illustrated by the various expressions used in referring to the patrimony. Thus Gelasius speaks of the patrimony as "res pauperum" 1 ; the same phrase is frequently employed by Gregory, who also uses the phrase "utilitates pauperum," and who, indeed, refers to the patrimony by some such expressions as these more often than by the ordinary title of "patrimonium," "possessiones" or "praedia Ecclesiae."

Of course the whole gross income of the patrimony was not applied to these purposes. The salaries of the officials connected with the administration, and the other necessary items of expenditure, formed a first charge on the revenue. The salaries of the officials under the rector were paid by him out of the revenue from his patrimony before the net income was de-

1 Jaffe, Reg. 684. Praestet igitur tua nobilitas ut rebus pauperum eius (beati Petri scil.) auxilium defensionemque concedat. Migne, 59, P. 155. 
spatched to Rome ${ }^{1}$, but the salaries of the rectors may have been paid from Rome, and the same must have been the case with the salaries of the defensors and other church officials when employed on papal missions not connected with the patrimony.

The salaries of the church officials and clergy were entered, together with the other payments made by the Church, in a large account book or "polyptichum," and we read that on one occasion, when pleased with the conduct of a certain Cyriac, a monk and also a defensor, Gregory called for the polyptichum and ordered his stipend to be increased and at the same time raised him to a higher rank among the defensors $^{2}$. The revenues from the patrimony were no doubt partially applied to the payment of the salaries of the church officials and clergy ${ }^{3}$, and also

1 Greg. Reg. I. 42. Sed pro labore suo statue quid accipiat ut ei vacuus labor suus esse non debeat (referring to Fantimus the defensor). See also below " actionario autem quem in eodem patrimonio deputasti prout tibi videtur ei aliquid largire."

${ }_{2}$ Ibid. II. 38. Moxque eum in gratiam familiariter recepi, coram clero polyptichum deduxi presbiterium ei auxi, in loco eum superiori inter defensores posui.

3 This is plainly stated by John the deacon: "cunctorum patrimoniorum praediorumque reditus ex Gelasiano polypticho cuius nimirum studiosissimus videbatur pedissequns adaeravit eorumque pensionibus in auro argentoque collatis omnibus ordinibus ecclesiasticis vel palatinis, monasteriis, ecclesiis, coemeteriis, diaconiis, xenodochiis urbanis vel suburbanis quater in anno distribuerenter," Vita S. Greg. II. c. 24, see also 25. But in view of the ridiculously small sums given to each of the clergy at Naples in the distribution referred to in Greg. Reg. XI. 22 (see p. I2I), it seems to me that most of the clergy must have been supported by some endowment, and that the distribution made by the bishop was in the nature of a bonus; originally it must have formed the sole support of the clergy, and the principle was maintained in a modified form even when endowments for each basilica, church, or oratory, had become the rule. 
in some cases to the payment of the sums required for the upkeep of the numerous churches in Rome. But it would be wrong to assume that all the money required for these objects came from the patrimonial revenue. Many, if not most, of the basilicas in Rome were endowed with lands which were managed by their own praepositi ${ }^{1}$, and did not form part of the patrimony; though it seems to have been the custom, when a pope founded a basilica, for him to allot for its support certain lands which had previously been included in the patrimony ${ }^{2}$; but these lands were struck out of the register (breve) of the patrimony on their transference to the praepositi of the basilica $^{3}$. The Roman Church also possessed another source of income, in the free-will offerings of the faithful ${ }^{4}$. It was probably from these, in the first place, that the sums were drawn which were allotted to the upkeep of the churches, the payment of the clergy, and the support of the pope himself, and we may suppose that it was only when these were insufficient for the purpose that they were supplemented by the revenue from the patrimony.

This revenue formed a kind of emergency fund

1 See Lib. Diurn. 68. Praeceptum de prepositatu.

2 E.g. endowments made by Popes Damasus and Innocent to the basilicas founded by them. See Lib. Pont. ed Duchesne, vol. I. pp. 212, 220-2.

3 Greg. Reg. xrv. 14.

4 There remains also the difficult question of tithes. For a discussion of this subject and a list of the authorities concerned, see Hauck-Herzog, Real-encyklopãdie für pro'estantische Theo. logie und Kirche, vol. xxI. pp. 63I seq., and Wetzer-Kaulen, Kirchenlexikon oder Encyklopädie der katholischen Theologie, vol. XII. pp. 1885 seq. 
which could be drawn upon by the pope in any case of grave necessity. Thus Gregory himself, when the Lombards were attacking Rome, seems to have bought them off with monies belonging to the Church $^{\mathbf{1}}$; and the revenues from the patrimony were, we know, employed, together with money supplied by private donors, in the redemption of captives taken by the Lombards in Campania and Southern Italy $^{2}$. From this source, also, came the gifts which the Roman Church, even in Gregory's time, sent to other churches in accordance with her ancient custom, and the various gifts which were sent by the pope to other patriarchs and foreign princes ${ }^{3}$.

When all allowances have been made, however, for these and similar expenses, there must have been a very large sum remaining annually from the total revenue, and this was expended entirely in works of charity and poor relief. Concerning the "problems of poverty" of that time we know very little, and the information on which the social historian has to rely is very scanty. It is plain, however, that in Rome a large part of the population was in a continual state of distress, and we may hazard the statement that the old worthless city mob, which had long lived upon the bounty of the emperors, still had its representatives, although much reduced in numbers. Indeed it is hard to see in what form of occupation the Roman population could at that time have been employed. That the population was still considerable

1 Greg. Reg. v. 39.

3 E.g. ibid. viII. 28, XI. I, 2.

2 Ibid. vi. 32, vIr. 23. 
is shown by the constant complaints of Gregory as to the insufficiency of the food supplies ${ }^{1}$, though not only the Church, but the State also, poured corn into the city; and we know, from statements of Gelasius and Pelagius, that in times of danger the population was swelled by an enormous number of refugees from all parts. But the imperial court had long ceased to exist, the imperial officials were but few in number, the troops hardly sufficient to man the walls, and the old Roman nobility was almost extinct, and there was thus no necessity for all those trades and industries which the support of an innumerable court or a luxurious society entails. Manufactures were almost non-existent, though a few of the guilds seem to have lingered on ${ }^{2}$; trade had declined to but a fraction of what it once had been, and thy unfortunate Romans could not even till the fields, outside their walls, in safety. There was thus little for them to do but to pass a pauperised existence on the doles they received from the Church and the State.

In the country, as contrasted with the city, a totally different state of affairs existed. The standard of comfort may not have been high, but no man needed to starve for want of a living; there was plenty of uncultivated land, and owners were only

1 Greg. Reg. I. 2, v. 36. John the deacon mentions that there were in Gregory's time 3000 nuns in Rome. The population cannot have been far off roo,ooo, unless these formed an astonishingly large percentage of the population.

2 There are references in Gregory's letters to the guilds of soap-boilers, fishermen, and to an argentarius or goldsmith, Reg. IX. II3, 200, XI. I6. There is also a reference in the Dialogues to the guild of dyers in Rome. 
too glad to get hold of capable coloni or slaves'. The only form of poverty that required special relief there was that due to impotence or old age.

It is interesting to note that even at this period there existed a certain amount of vagrancy, though it might have been thought that the unsettled condition of the country would have discouraged all travelling other than what was.absolutely necessary, and rendered even vagrancy dangerous and unpleasant. But it is plain from the Dialogues that a regular class of vagrants existed. There is one amusing reference to that ancient institution the organ grinder and his monkey ${ }^{2}$, and there is another reference to certain professional beggars who, having hidden their clothes, arrayed themselves in rags and went to beg of Saint Isaac of Spoleto ${ }^{3}$. Gregory himself tells us that he had as his authority for some of his stories an old travelling man and that he loved to talk with such men".

1 Cf. Greg. Reg. Ix. 203, where it is related that the coloni of the church of Cagliari had deserted their massae and were working on the lands of private persons.

${ }^{2}$ Greg. Dialogue, lib. I. c. 9. "But before the table was yet blessed, suddenly (as some men by such means get their living) one came to the gate with an ape, who began to play upon an instrument, hearing which the holy man was disconcerted and said 'Alas, this wretched man is dead, this wretched man is dead. Behold I am come hither to dinner and have not yet opened my lips to praise God, and he is here with his ape playing upon his instrument.' Then he desired them to give him some meat and drink: 'Yet I would have you know, quoth he, "that he is a dead man'."

3 Ibid. lib. 3. c. I4.

4 Ibid. lib. I. c. Io. "Neither must I pass over with silence that which I heard almost twelve days since: for a certain poor old man was brought unto me (because I loved always to talk with such kind of men) of whom I enquired his country." Note 
From the earliest times the Church had made provision for the poorer brethren ${ }^{1}$, and the main outlines of the system were common to all the individual churches, that of Rome included. In order that in every church a regular sum should be forthcoming, it had been laid down that the revenues should be divided into four portions, one for the bishop, one for the clergy, one for the upkeep of the churches, and one for the poor. The observance of this rule was insisted on by the popes ${ }^{2}$, and in the formula, given in Liber Diurnus, of the oath to be taken by a bishop on his consecration, a clause is inserted binding him to observe this distribution ${ }^{3}$. In the case however of Rome and of other churches, such as those of Milan or Ravenna, which possessed large patrimonies, it does not seem that the revenue from these estates was subject to this fourfold division. It would seem hardly reasonable, in the case of churches possessing such enormous incomes, that the bishop should take a quarter of the whole, or that another quarter should be allotted for the upkeep of the fabric of the churches. In these cases the patrimonial revenues were most probably exempted from the rule and formed a separate fund,

also that free beggars could be made coloni as a punishment for mendicancy. Savigny, Der röm. Colonat, p. II.

1 Acts iv. 34, 35. Romans xv. 26. Galat. ii. ro.

2 The two earliest ordinances for this fourfold division of the offerings of the faithful are those of Popes Simplicius and Gelasius I (Gratan, Decretum, c. 28 and 27, C. XII. qu. ii).

${ }_{3}$ Lib. Diurn. 74. Quartas vero clericis vel fabricis portionem me annis singulis sine aliqua imminutione spondeo prestaturum. 
the expenditure of which was in the discretion of the bishop.

The decision as to the distribution of the share allotted for poor relief seems to have been in the hands of the bishop, and there exists a very interesting letter of Gregory to Paschasus, bishop of Naples, suggesting the method in which he should distribute the shares of the clergy and the poor for the previous year, which had not been distributed by his predecessor ${ }^{1}$. The sum to be divided was 400 solidi and Gregory suggests that the senior clergy of Naples (praejacentes) should have 63 solidi, or half a solidus each, as there were I 26 of them ${ }^{2}$; that the inferior clergy should have roo solidi; that 50 solidi should be given to foreign clergy residing in Naples; that I50 solidi should be given to poor and honest persons who were ashamed to beg, a tremessis or two, or even a solidus or more, according to their needs; and 36 solidi to the poor who were accustomed to beg in public. It will be noticed that 213 solidi were to be given to the clergy and $x 86$ to the poor, and this is interesting as showing that the division of the revenues into four parts did not necessarily mean that they were to be of equal amount.

In each church a roll called a "matricula" was

1 Greg. Reg. XI. 22.

2 The fact that the superior clergy only received half a solidus each, while the "honesti ac egeni homines" might receive a solidus or more, shows that this payment cannot possibly have formed their real stipend and that the quarter of the revenue given to the clergy had come to be merely a customary payment of little value. 
kept with the names inscribed on it of the persons in receipt of relief from the Church. The persons on the matricula were called "matricularii" and seem to have received an allowance of food each day from the Church; a special building was set apart in which the matricularii dined. In later times it seems that the matricularii rendered certain services to the Church in return for their support, and it is clear that the Church exercised, or claimed to exercise, some jurisdiction over them, for we possess one letter of Gregory in which he sternly rebukes a bishop for having ordered a poor woman on the matricula to be scourged ${ }^{1}$. The same system obtained in Rome, and John the deacon states that there existed in his time a large register, dating from the time of Gregory, which contained a list of the names and a description of all the persons of both sexes in Rome and the suburban towns who were in receipt of relief from the Church ${ }^{2}$.

It may be noted here that the quarter share of the "oblationes fidelium" referred to above did not constitute the total sum allotted to poor relief in each church. The diaconiae possessed special endowments of their own, and there were probably, in addition, other funds which had been left by pious persons for

1 Greg. Reg. III. 44.

2 Exstat usque hodie in sacratissimo Lateranensis palatii scrinio huius confectum chartaceum praegrande volumen in quo communis sexus cunctarum aetatum ac professionum nomina tam Romae quam per suburbana civitatesve vicinas ... degentium cum suis cognominibus, temporibus et remunerationibus expressius continentur. John. Diac. Vita S. Greg. lib. II. c. 30 . 
supplying food and clothing to the matricularii and the poor generally.

The means by which the relief was distributed and administered to the matricularii were the organisations known as "diaconiae," which term included not only the buildings in which the distribution was made (also called matriculariae) but the whole system of organisation. Originally in the primitive church the officers charged with the duties of poor relief had been the deacons, and the name diaconia had survived in the organisation from that period; when, however, the deacons became more and more absorbed in spiritual duties, the work of poor relief was passed on in the first instance to the sub-deacons, and eventually, in large churches, such as that of Rome, to the defensors and notaries ${ }^{1}$. In Rome, for purposes of poor relief, the city had been divided into seven districts by Pope Fabian $(236-250)^{2}$ and over each of these he placed a deacon, a sub-deacon and a notary. To the seven regionary deacons, sub-deacons, and notaries seven regionary defensors were added by S. Gregory ${ }^{3}$.

The nature and organisation of the diaconiae are well fllustrated by a formula given in Liber

1 Laymen may possibly have been appointed notaries. See Lib. Diurn. 70. Praeceptum quando laicus tonsoratur et fit regionarius.

2 Catalogus Liberianus, 9r, given in Duchesne's edition of the Lib. Pont. pp. 2-9. These seven districts were formed by combining in each case two of the fourteen imperial divisions of the city. See Gregorovius, Hist. of Rome, vol. I. pp. 80-82, and Rossi, Roma sotterranea cristiana, vol. III. p. 5 I 5 seq.

${ }_{3}$ Greg. Reg. virr. I6. 
Diurnus allotting certain lands to the support of a diaconia ${ }^{1}$. The formula opens with a recital that provision ought to be made for the upkeep and advantage of sacred places and especially those "in quibus omnipotentis laudes referuntur et sedula fratribus nostris Christi pauperibus sumministrantur alimonia, quatenus omnium egentium, inopum etiam proselytorum copiosa proficiant subsidia et ex hoc redemptori nostro hoc ipsum quod ad gloriam sancti nominis eius dinoscimur procurasse." Certain lands are then allotted for the support of the diaconia for ever, and the hope is expressed that when the meal is finished all the attendants and poor will join in prayer for the Pope; "id est quando lusma perficitur in eadem diaconia pro remissione peccatorum nostrorum omnes diaconite et pauperes Christi qui ibidem conveniunt exclamare studeant ${ }^{2}$." Provision is then made for the entry of the income (pensio) of the diaconia in the church accounts, probably in order. that the church officials might be able to examine and supervise its management ${ }^{3}$. Lastly an anathema is pronounced against any who should attempt to deprive the diaconia of the lands assigned to it; these are to remain "in propria utilitate et usu praefatae venerabilis diaconiae pro sustentatione et alimoniis

1 Lib. Diurn. 95. Privilegium de diaconiis.

2 "Kyrie eleison" is added in two MSS.

3 Probably in many cases the revenues of both diaconiae and xenodochia, from their endowments, exceeded the expenditure; the surplus would be paid into the treasury of the Church and not allowed to be retained by the dispensator for himself. Note the instructions given by Gregory to Peter the sub-deacon in r. 42. "Pensiones xenodochii de Via Nova quantas mihi indicasti quia apud te habes nobis dirige." 
fratrum nostrorum Christi pauperum perpetuis temporibus." This formula is interesting as showing that an endowment out of the patrimonial estates was commonly given to a diaconia set up in Rome, and similar endowments were probably possessed by the diaconiae existing in other cities; indeed there is a reference in one of Gregory's letters to a legacy of all his property left by a citizen of Pisaurum to the diaconia there, contingent on his son not attaining the age of $2 I^{1}$. We may note in passing that the provision in the formula quoted above for the supervision, by the church officials, of the accounts of the dispensator of the diaconia does not occur in the patent of appointment as dispensator given by Gregory to a certain John religiosus, probably a monk, who was freed from the necessity of giving any account of the expenses incurred in management ${ }^{2}$.

In the case of Rome the supplies distributed through the diaconia consisted largely of the corn bought by the Church, in Sicily and other corn-producing provinces, with the revenues supplied from the patrimony. But this did not form the only source of supply. As we have seen in Chapter IV, it was the common practice of the State to entrust to the Church the distribution of the imperial largess or of the annonae granted to the poor in time of stress.

1 Greg. Reg. v. 25.

2 Ibid. xI. I7. Ut de hoc quod ad mensas pauperum vel diaconiae exhibitionem percepisti sive subinde perceperis erogandum, nulli umquam hominum quolibet modo seu ingenio cogaris ponere rationem vel aliquam debeas molestiam sustinere. Sed quia ita ab humanis te omnibus esse volumus rationibus absolutum, etc. . 
ThusCassiodorus, in one of his letters, refers to a royal distribution of corn at Milan, the management of which was entrusted to the archbishop Datius ${ }^{1}$; and the letter of Gregory to Cyridanus, the overseer of the imperial "sitonicum" at Rome, proves that the annonae there had been usually distributed by the church officials ${ }^{2}$. The same system prevailed in Naples, and Gregory reproaches John, the praetorian prefect of Italy, with having, on his appointment, stopped the grant of annonae to the diaconiae there, and suggests that, even if he wished to save the cost to the State, it would not have ruined him to have continued the grant out of his own pocket ${ }^{3}$. But the supplies administered through the diaconiae were not confined to corn; clothing and all kinds of food and necessaries were distributed by them, and the gifts of wine, cheese, meat, fish and oil, which John the deacon states were given by Gregory to the poor at the beginning of each month according to the season were probably made through the diaconiae at Rome 4

So far only the provision made for the maintenance of the poor, provision which would now be called outdoor relief, has been considered; we must now turn to the provision made for vagrants and poor travellers

1 Cass. Var. xIr. 27.

2 Greg. Reg. IX. II5. See also v. 36, IX. 5.

3 Ibid.x. 8. Quod etsi forte nullus vestris voluisset rationibus imputare, hoc de proprio vos impendere non debuit gravare precario.

4 Johannes Diac. II. 26. Omnibus omnino kalendis pauperibus generaliter easdem species quae congerebantur ex reditibus erogabat: et suo tempore frumentum, suo vinum, suo caseum, suo legumen, suo lardum, suo manducabilia aimalia, suo pisces vel oleum paterfamilias Domini discretissime dividebat. 
and for the sick and impotent. This form of relief was administered through institutions known as "xenodochia," and, while the doles of food distributed through the diaconiae were only necessary in the case of a city population, the provision of infirmaries and rest houses was as necessary in the country as in the town, and the xenodochia were therefore widely scattered over all the country districts ${ }^{1}$. But before passing on we must note an important distinction between the management of the diaconiae and that of the xenodochia. The diaconiae formed part of the 2 d 2 $60 \mathrm{~m}$ " ancient diocesan organisation of the Church; they were a regular institution in every diocese and were under the direct control of the bishop. Thus the Church of Rome was responsible only for the diaconiae in that city, and if the dwellers on the Roman patrimony were in need of relief it would be administered to them through the diaconiae of the diocese in which they dwelt. But the xenodochia, like the monasteries to which they were frequently attached, originated in the East and were introduced into the West only at a comparatively late period. Like the monasteries they had a universal as opposed to a local character and were always attempting to escape from episcopal control. This tendency on the part of all monastic institutions was favoured by the Papacy, which by frequently granting them exemptions and privileges brought them more and more under its own supervision and utilised them as a means of spreading

1 E.g: there are references in Gregory's letters to many xenodochia in Sicily. 
Roman influence ${ }^{1}$. The xenodochia, though subject to episcopal inspection, were thus, in reality, under papal control, and the Roman Church was responsible for their good order and management; this applied to those xenodochia situated outside the patrimony as well as to those within its bounds ${ }^{2}$.

The xenodochia did not share in the distribution of the revenues of the various churches; as in the case of the monasteries, they were usually the foundations of private persons and were supported entirely, by the endowment made over to them at the time of their creation $^{3}$; and they were the recipients of numerous

1 See Greg. Reg. XIII. II for privileges given by papal diploma to a monastery and xenodochium founded at Autun by Brunhild and Syagrius.

2 In some cases the xenodochi seem to have had to submit their accounts to the bishop of the diocese. See Greg. Reg. IV. 24, "Quamobrem significamus pervenisse ad nos consuetudinem fuisse ut xenodochia quae sunt in Caralitanis partibus constituta apud episcopum civitatis singulis quibusque temporibus suas subtiliter rationes exponerent eorum videlicet tuitione atque sollicitudine gubernanda." But the mention of the special custom in this church shows that it was not usual. See also ibid. I. 42, "Pensiones xenodochii de Via nova quantas mihi indicasti quia apud te habes nobis dirige." Those xenodochia situated in Rome were of course entirely under the Pope's control, both episcopal and papal jurisdiction being united in his person. There seem to have been several xenodochia in Rome, e.g. that of Via Nova (1.42), that of Valerius (Ix. $66 a, 82$ ), that of the Anicii (IX. 8), and others mentioned in Hartmann's note on Ix. 63.

3 As has been mentioned before the xenodochi had to render accounts to the church officials and if the revenues exceeded the expenditure the surplus was paid over to the Church. The Church would come to the help of a xenodochium when extraordinary payments were necessaty, but the sums advanced had afterwards to be repaid out of the revenues of the xenodochium. See Greg. Reg. II. 38.

Probably the papal licence for the foundation of a xenodochium would not be given unless the church officials were 
legacies and benefactions ${ }^{1}$. Each xenodochium was managed by an official known as the "xenodochus," who was generally a monk ${ }^{2}$, and who, as was the case with monks, could make no will without the papal $<2$
licence.

The purpose of a xenodochium seems to have been two-foll $f$ on the one hand to provide board and lodging for vagrants, poor travellers and pilgrims, and on the other 4 and this seems to have been the more important side-to act as a hospital and in- ( 2 ) firmary and give free medical attendance. A formula in Liber Diurnus for the appointment of a xenodochus lays gréat stress on this side of the work and gives an interesting account of the appointed person's duties $^{3}$. He is to hold the office for life "ea prorsus ratione ut in eodem venerabili loco lecta cum stratis suis tuo studio praeparentur in quibus egros semper suscipias et egenos eisque curam adhibeas et necessaria tribuas confectionem oleorum infirmantibus atque indigentibus annue facies atque praepares vel omnia quae infirmantium necessitati sunt utilia, medicos introducens et curam egris impendens, ut tali tuo studio Christus deus noster possit placari atque praesens praeceptio cunctis diebus vitae tuae maneat imperturbata, ne si neglexeris divinae indigsatisfied that an ample endowment had been provided. See Greg. Reg. IX. 35.

1 Greg. Reg. IX. 35, 63, I30, XIII. 28.

2 The xenodochia in Rome do not seem to have been connected with monasteries. In the formula in Lib. Diurn. 67 . the person appointed is a notary, in Greg. Reg. Ix. 66 a subdeacon and in IX. 8 a deacon. For papal licence to a xenodochus to make a will see ibid. I. 9 .

${ }^{3}$ Lib. Diurn. 66. See also another formula given in 67 .

S. P. 
nationi incurras et iuste talius dispensationis frustreris." Under the xenodochus was a large staff of attendants, and these seem to have been as a rule church slaves; at any rate there exists a letter of Gregory ordering a rector to assist a notary who had been sent to Sardinia to purchase slaves for the use of the "ptochia1." That the xenodochia were often large establishments is shown by the request ${ }^{2}$ of one xenodochus for ten mares for the use of his institution $^{2}$. In towns or villages where xenodochia did not exist their place was largely taken by monasteries, though the tendency at this period was to insist on the contemplative side of the monastic life $^{3}$. Eventually the xenodochia as separate institutions seem to have disappeared, and their work was continued by the monasteries which absorbed them.

So far we have considered the ordinary channels in which the revenues from the patrimony were expended and the ordinary forms of poor relief; but, as has been said above, the revenue from the patrimony formed a reserve fund which could be drawn upon by the Pope for any special objects. Gregory employed it on one occasion to buy off the Lombards, and he used it, as a matter of course, as the fund out of which to make grants for special charitable pur-

1 Greg. Reg. IX. I23. "Ptochium" seems to mean exactly the same thing as "xenodochium." It is defined by Du Cange as "Domus pauperum hospitio deputata." See also ibid. II. $3^{8}$.

2 Ibid. Ix. 8.

3 Cf. ibid. I. 67 in which Gregory desires that Faustus, expraetor and cancellarius, may be appointed to conduct the business affairs of the monastery, as he does not wish the monks to be troubled with business or law suits. 
poses or to individuals. In this way a great deal of the revenue found its way back to the various patrimonies from whence it came. In the case of the Gallic patrimony Gregory directed that, since the difference in value between Gallic and Roman solidi rendered it useless to send the cash to Rome, the revenue should be expended so far as possible in poor relief in Gaul itself ${ }^{1}$. Besides the steps which he took to improve their general position Gregory made many gifts to individual coloni; thus we find an annuity given to Albinus, the blind son of a colonus ; a plot of land given to another colonus rent $\mathrm{free}^{3}$; and gifts made to the coloni who had suffered from the extortions of the conductors.

But Gregory's charity was boundless and almost indiscriminate, and it is hopeless to attempt to classify it in any way. We find gifts of annuities, of money, of clothing, of foodstuffs, and the recipients include persons of every kind and standing; thus we find among them bishops, nuns, priests, monks, defensors, recalcitrant clerics, widows, Gregory's own aunts, a merchant, blind men (towards the blind Gregory was especially generous), an ex-judge and an ex-praetor, the children of Jewish converts, a bankrupt Syrian merchant and many others. Gregory's gifts moreover were not confined to individuals; a large gift of 1000 to 2000 measures of wheat, for

1 Greg. Reg. vi. Io.

3 Ibid. 1x. 37, xiIr. 37.

4 See for example $i b i d$. 1. $23,18,37,42$, II. 38 , IV 31,43 , XI. 3, XIV. 15. For gifts to blind persons see I. 44, 65, IV. 28 , Ix. 235 . 
example, was sent to a bishop for distribution among his poor ${ }^{1}$, and at the consecration of monasteries situated on the patrimony, the feast which it was usual for the monastery to give to all the neighbourhood was usually provided by the Church; in one such case Peter the rector of Sicily was ordered to distribute to the poor Io solidi, 30 amphorae of wine, 200 loaves, 2 jars of oil, I2 sheep and roo fowls ${ }^{2}$. Gregory's charity did not always take the form of gifts in kind or money; we find also reductions of rent, remissions of debts, loans advanced at low interest, and protection given to debtors ${ }^{3}$.

Of Gregory's personal charity John the deacon tells us something. He relates that the Pope's custom was to invite twelve strangers to dine at his table daily and every day he sent hot dishes from his own kitchen to the impotent and infirm in various parts of the city 4

No doubt Gregory was often imposed upon. His letters show that some of the church agents did not always approve of his benefactions ${ }^{5}$, and John the deacon relates that after his death the people reviled

1 Greg. Reg. vi. 4.

2 Ibid. 1. 54

3 See ibid. IX. 108, where the rector of Campania is ordered to try to induce a certain nobleman, Felix, who had lent 400 solidi at 25 per cent. interest and had already received 4 IO solidi in repayment, to forego the remainder of his interest "as becomes a Christian and a gentleman."

4 Johannes Diac. II. 23, 28. Alio quoque tempore idem Gregorius iuxta consuetudinem suam praecepit sacellario suo ut duodecim peregrinos ad prandium invitaret.

Quotidianis quibusque diebus per omnium regionum vicos vel compita infirmis seu qualibet corporis parte debilibus cocta stipendia per constitutos veredarios emittebat.

5 Greg. Reg. IX. 48, 199. 
him as one who had wasted the church goods; but Gregory, and the Church generally, felt that in these matters it was better to err on the side of generosity than on that of meanness. That the church system of care for the poor was wonderfully effective is shown by one striking fact. John the deacon relates that on one occasion a man was found to have died of hunger in Rome and Gregory was so struck to the heart that he refused for many days to celebrate Mass ${ }^{1}$.

In comparison with this it is humiliating to know that in the year IgI 2 in the county of London, in spite of our organised system of poor relief and innumerable charitable agencies, forty persons died "of starvation or of causes accelerated by privation"."

Such was the method in which the Church of Rome expended her revenues in the sixth century. She had a noble trust imposed upon her and nobly she performed that trust. If the Church in succeeding ages had been equally conscious of her duties the task which social reformers are now called upon to face might be very different from what it is.

1 Johan. Diac. II. 29. Ita per aliquot dies, ut dicitur, a missarum celebratione vacando tristatus est, tanquam si eum propriis manibus, quod dictu nefas est, peremisset.

2 See The Standard of Jan. 23rd, I9I4, quoting from a parliamentary return. 


\section{APPENDIX I}

I quote from Marini (Papiri Diplomatici, no. 93) the following deed of gift to the church of Ravenna as a good example of the usual form of a conveyance of land to the Church. It will be noticed that the donor Sisivera was a freedwoman and received the lands which she was about to make over to the Church from her former mistress Theudifera when she was freed by her. The clauses in the deed are as follows:

I. Parcels.

2. Reservation of usufruct to the donor for ten days.

3. Conveyance of the lands in perpetuity after the expiration of the usufruct.

4. Covenant by the donor for undisturbed possession by the Church and stipulation that she will not take advantage of laws made for the protection of women to revoke the gift.

5. Signature by the donor and attestation by witnesses.

The first few sentences of the deed are missing. The Latin throughout is of the most barbarous kind.

\section{Marini. Papiri diplomatici, 93.}

et in jur...omni... in potestatem perpetem transcribo cedo trado et mancipo id est ex fundum cui vocabulum est Balonianum omnem portiunculam meam in integro cum terris et vineis et omnibus 
generaliter et specialiter ad memoratam portiunculam meam longo latere pertinentibus constitutam territorio Ariminensi inter adfines circumcirca tam in suprascripto fundo Baloniano quam in aliis fundis possedentes a praedicta sacrae Ravennense Ecclesia qui nunc sunt et si qui alii adfines sunt q.q. tt. et populum finibus terminis campis, pratis, pascuis, silvis, salectis, sationalibus, vineis, arbustis, arboribus pomiferis, fructiferis et infructiferis diversisque generibus rivis, fontibus, aquis perennis, liminibus limitibusque suis omnibus omnique jure proprietateque eius sicuti a me meaque patrona auctores et proauctores bono, optimo, maximo et inconcusso jure possessum est atque nunc usque in hodie rite possedetur ita et a me traditur a praesenti die suprascriptae sacrae Ecclesiae Ravennensi pro remedium animae meae inperpetuo possedendum: venientem mihi ex destinatione suprascriptae quondam Theudiferae patronae meae quam mihi concessit ad confirmandam libertatem: de quam praefatem portionem meam in integro fundi suprascripti Baloniani cum omnibus ad se generaliter pertinentibus reteneo mihi usufructum dierum decem quod possit suprascriptae sacrae Ravennensi Ecclesiae actoribusque eius ut leges censeunt pro solemni et corporali traditione constare. Post vero transactos dies usufructuarios meos memoratam portionem fundi suprascripta praedicta Ecclesia Ravennensis actoresque eius habeant, teneant, possedeant juri dominioque more quo voluerit inperpetuo vindicent atque defendant vel quidquid ex eadem portionem juris mei facere maluerint per quolibet contractu liberam et perpetem in omnibus potestatem. Contra quam etiam inrevocabilem donationis meae pagina polliceor nunquam esse venturam neque per me neque per heredes successoresque meos adversus praedicta sacra Ecclesia Ravennensis actores- 
que eius quoniam et legibus cautum est ut quod semel in loca venerabilia donatum vel quoquo modo cessum fuerit nullo modo revocetur: et pro maiori firmitatem jurata dico per Dominum omnipotentem et sacra quatuor Evangelia quos corporaliter manibus meis teneo salutemque dominorum invictissimorum principium Augustorum Romanum guvernantum Imperatorum attestatione confirmo me ut superius dixi contra numquam esse venturam sed inviolabiliter tam me quam heredes meos conservatura esse spondeo, excluso erga me omnium legum beneficia quae de revocandis donationibus et de sexu femina Bellianus senatus-consultus mulieribus subvenire adsolet: quoniam ad hanc largitatem meam sponte et habita deliberatione perveni nullius cogentis $\mathrm{i} \overline{\mathrm{m}} \mathrm{p}$. nec suadentis impulso et haec inrevocabiliter me donasse profiteor: quam donationis meae paginam omni vi, dolo, metu et circumscriptione cessante Bono Tabellioni huius civitatis Ravennae rogatario meo scribendam dictavi in qua subta propria manu pro ignorantia litterarum signum venerabilem sacrae Crucis feci et testibus a me rogitis optuli suscribendam quam si gestis municipalibus allegare voluerint actores ecclesiae liberam tribui ex more licentiam allegandi. De qua re et de quibus omnibus suprascriptis stipulatione solemniter interposita. Actum Ravennae die et Imperatore suprascripto + .

Signum + Sisiverae hf. suprascriptae donatricis omnia suprascripta agnoscentis et consentientis cui et relecta est + .

Armatus.vd. Scolax huic chartulae donationis portionis in integro fundi suprascripti Baloniani cum omnibus ad se generaliter pertinentibus sicut superius legitur facte in sacra ecclesia Ravennense a suprascripta Sisivera hf. donatrice quae me praesente signum sacrae Crucis fecit et coram nobis ei relicta est 
rogatus ab eadem ad signum eius roborandum pro ea testes et Chirochrista subscribi et de conservandis omnibus suprascriptis ad Evangelia corporaliter praebuit sacramenta et hanc donationem a suprascripta Sisivera palam Bo u.u. diacono et vicedomino traditam vidi.

The remaining attestatory clauses are similar. The attesting witnesses are:

Adquisitus Opt. Nū̄. victr. Mediol.

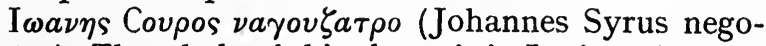
tiator). The whole of this clause is in Latin written in Greek characters.

Laurentius vir st. ex Epod.

Julinus uh.

Juvinus uh, orrearius.

Final attesting clause by the writer of the deed.

Bonus Tabellio Civitatis Ravennae scriptor huius chartulae donationis portionis in integro fundi suprascripti Baloniani cum omnibus ad se generaliter pertinentibus sicut superius legitur post roboratam a testibus atque traditam complevi et absolvi. 


\section{APPENDIX II}

\section{BIBLIOGRAPHY}

\section{Original Authorities}

Gregorii I Papae Registrum Epistolarum, ed. Ewald and Hartmann, in Monumenta Germaniae. Historica. Berlin, I887-1895.

S. Gregorii Papae I. Opera omnia. Migne, Patrol. Lat.

Vols. 75-79. Paris, 1849.

Dialogues of S. Gregory. Translated by P. W. Ed. E. G.

Gardner. London, I9II.

Johannes Diaconus. Vita S. Gregorii. Migne, Patrol. Lat.

Vol. 75. Paris, 1849 .

Paulus Diaconus. Vita S. Gregorii. Migne, Patrol. Lat.

Vol. 75. Paris, 1849 .

Liber Pontificalis, ed. Duchesne. Paris, 1886.

Liber Diurnus, ed. Th. E. ab Sickel. Vienna, I889.

Cassiodorus. Opera omnia, ed. J. Garet. Rouen, I679.

Jaffé, E. Regesta Pontificum Romanorum. 2nd ed.

Leipsic, $\mathrm{r} 884$.

Mansi. Sacrorum Conciliorum Nova Collectio. Florence, I 763 .

Marini. I Papiri Diplomatici. Rome, I805.

Salvian. De Gubernatione Dei. Migne, Patrol. Lat.

Vol. 53. Paris, 1849 .

\section{Books of Reference}

[The following list contains only those books to which frequent reference is made in this essay. For a complete bibliography of the subject, see The Cambridge Medieval History, vols. I and II, especially the bibliographies to chap. XIX, vol. I, and chaps. III and VIII, vol. II, and the General Bibliography to vol. II.] 
Borgia. Breve istoria del dominio temporale della Sede Apostolica nelle due Sicilie. Rome, I788.

Du Cange. Glossarium mediae et infimae Latinitatis, ed. Favre. Niort, I 883 .

Dudden. Gregory the Great, his place in history and thought. London, 1905.

Gregorovius. History of the City of Rome in the Middle Ages. Trans. Hamilton. London, I 894.

Grisar. Rundgang durch die Patrimonien des heiligen Stuhles um das Jahr 60o. Verwaltung und Haushalt der päpstlichen Patrimonien um das Jahr 6oo. Articles in Zeitschrift für katholische Theologie. Innsbruck, I877.

Gwatkin and Whitney. The Cambridge Medieval History. Vols. I and II. Cambridge, I9II-I9I3.

Hartmann. Untersuchungen zur Geschichte der Byzantinischen Verwaltung in Italien $54^{\circ}-75^{\circ}$. Leipsic, I889.

Hunter, W. A. Introduction to Roman Law. $5^{\text {th edition. }}$ London, 1897.

Savigny. Vermischte Schriften. Berlin, I850.

Tomassetti. La Campagna Romana, antica, medievale, e moderna. Rome, I9Io.

Zaccaria. De rebus ad historiam atque antiquitates Ecclesiae pertinentibus. Fulginiae, I78r.

Hauck-Herzog. Real-encyklopädie für protestantische Theologie und Kirche. Leipsic, I896-rgr3.

Wetzer-Kaulen. Kirchenlexikon oder Encyklopädie der katholischen Theologie. Freiburg-i.-B., I882-I901. 


\section{INDEX}

Acta Sylvestri, 4

actionaries, duties of, 37

Adeodata, abbess, $98 \mathrm{n}$.

Adeodatus, $47 n$.

Adrian, rector of Syracuse, $36 n$.

adscriptitius, synonym of colonus, $54 n ., 5^{8} n$.

affines, boundary stones, 42

Africa, exarch of, 16, 17, 104, 105

- patrimony in, I7, $55 \mathrm{n}$, I04, 105

Agatho, Pope, 70 n., 96

Agrigentum (Girgenti), 7

Albinus, son of a colonus, 131 Alexander Frigiscus, colonus,

\section{7}

Amalfi, bishop of, 98

Ampliatus, conductor, 107

Anastasius, law of, 56

Anicii, xenodochium of, 128 $n$.

annonae, grants of corn, 99, 125,126

Anthemius, sub-deacon and rector of Campania, Io, $26 n$. 27, 99

Antoninus, defensor of Sicilian patrimony, 5, 35

- defensor and rector of Dalmatia, 18

apocrisiarius, papal legate, I3, 3I

Appian Way, patrimony of, I2

Apulia, patrimony of, 9

Aquae Salviae, $24 n ., 4 \mathrm{I} n$. aquimolae, water mills, $44 n$. Arcadius, law of, $60 n$. arcarius, treasurer, 39, II2
Arigius, patrician, $15 n ., 25$ n., 68

Arles, Licerius bishop of, 14 , 22

- Sapaudus bishop of, 14

- Virgilius of, I5, 22

Asia, Roman estates in, 19

Augustine, mission to England, 16

Autun, 15 n., 128

Avars, raids of, I3, I8

Baronius, lists quoted by, 19

Basilius, bishop of Capua, I 13

- a sorcerer, $92 n$.

Bassus, accuser of Pope Xystus, 4

Bede, I 4

Belisarius, I7

Benedict, abbot, $33 n$.

- notary and rector of Carseolum, I I, $36 n$.

Benegestus, defensor, 102

Benenatus, notary and rector of Samnium, 9

- bishop of Misenum, 99

Bianchini, estimate of revenue from patrimonies, I9 $n$.

Bishops, property of, 4

- share of revenue allotted to poor, 29, II $5 n$., I20, I 2 I

- as rectors of patrimony, 22

- position in law-suits, 30

Boniface, deacon and rector of Corsica, 17, $36 n$.

- notary, 82

- church treasurer, II3

breve, register of estates of patrimony, 23, 24, I I6

Brunhild, Queen, $15 n$., 128 $n$. 
Bruttium, patrimony of, 7,8 , coloni, legal and social posi$70,96 n$.

- rector of, 7,27

burdatio, land-tax, 70, 7I

Cagliari, 16, 60, I I9 $n$.

Calabria, patrimony of, 8,9 , 70 n., 8I

Callipolis (Gallipoli), 9, 64 n., 98

Campania, patrimony of, ro, II

- rector of, 27, 8I, 82, $88 n$., $132 n$.

Candidus, priest and rector of Gaul, I5, 25 n., 3 I $n ., 64 n$., $68,82,89$

- defensor and rector of Tuscany, 12

capitatio, poll-tax, 68,69

capitulare, list of instructions, 24

Capri, $74 n$.

Capua, bishop of, $103 n$.

Carseolum, patrimony of, I I

- rector of, III

casale, farm, ? large field, 42, $43 n$.

Cassiodorus, Varia, 32, 33, 34, 65 n., 67 n., 71, 73 ., 8I, IOo, IOI $n$., I 26

Castorius, notary, $13,36 n$.

cautio, copy of rector's oath, 24 censitus, synonym of colonus, 54 n., 69

Cethegus, II 3

chartulary, equivalent to notary, 36, 39

Childebert, King, $15 n$.

Clerentius, slave, $8 \mathrm{I}$

Codex Justinian., 38, 56-64, 82,85

Codex Theodosian., 3, 32, 55, $63,65,69,82$

coloni, taxation of, 9

- some still pagan, I6, 9I

- relations with rector, 24 28

tion, 54-79

- liable to military service, 97

- suffered extortion from officials, I04

- payment of pensio, 107

- in demand as labourers, II9

Comitacius, count of Misenum, 99

conductores, property of, 5

- relations with rector, $25-$ 28

- legal position of, 48-54

- relations with coloni, 7476

- collection of revenue from, I07-109

conduma, farmstead, 43

Conon, Pope, 96

Constantia, Empress, I6

Constantine the Great, $1-4$, I9, 63 n., 65

- Pogonatus, 96

Constantinople, patrimony of church of, $38,39,47$

Corsica, patrimony in, 16,17

- coloni still pagan, I6, 9I

- sufferings of tax-payers, 70, I04

Cosmas, a Syrian trader, 89

Cottian Alps, patrimony in, I3, I4

Cyprian, deacon and rector of Sicily, 7, 23 n., 77, 91

Cyriac, monk and defensor, II 5

Cyridanus, overseer of corn supply, $25 n ., 95 n$. roo, 126

Dalmatia, patrimony in, $5 n_{:}$, I8, I9

- rector of, I8, 22, III

Damasus, Pope, I16 $n$.

datitii, barbarians who became coloni, $55 n$. 
Datius, archbishop, 126 deditii, see datitii, $55 n$. defensor civitatis, 32, 33 defensor ecclesiae, position in administration of patrimony, 14, 33-36

- - ecclesiastical status of, 23 36

- pseudo-defensors, 35 , - - concerned in work of poor relief, 123

Desiderius, of Vienne, $15 n$.

desuscepta, receipts, II3

diaconiae, organisations for poor relief, 122-127

Dionysius, bishop of Corinth, 2

domusculta, 43

Donatists, wars with, $\mathrm{r} 7$

Du Cange, Glossarium, I30 $n$.

Dudden, Rev. F., Gregory the Great, xvii, ro $n$.

Dynamius, rector of Gaul, I5, 22

ecclesiastical law, 30

- property, sale or lease of, 45-52

emphyteusis, form of lease, $46-49,52 n$.

Epiphanius, deacon, $46 n$.

Eugenius, rector of Tuscany, 12, $36 n$.

Eulogius, patriarch of Alexandria, 27

Eumorfiana, island off $\mathrm{Na}$ ples, II, 27

Eusebius, Hist. Eccles., 2

Eustachius, Saint, diaconia of, 48

Ewald, reference to notes of, $38,43,64,73$

exarch of Africa, I6, I7, 22, 104

- of Ravenna, 10, 104

excepia, small payments in kind, $68,74,75$
Fabian, Pope, 123

Fantinus, defensor in Sicily, 37,95

Faustus, ex-praetor, $130 n$.

Felix III, Pope, 33

Felix, sub-deacon and rector of Appian patrimony, 12

- conductor, $5 \mathrm{I}$

- defensor, 84

Ferrocinatus, $43 n$.

Florianus, I03

Franks, kingdoms of, I4, 15

fundi, farms, 7, 4I, 42

Gaudiosus, magister militum, I7

Gaul, patrimony in, $5 n ., 6$, $14-16,76 n$.

- rectors of, 15, 18, 22, $23 n$., 3I $n ., 68,82$

Gela, massa of, 108

Gelasius I, Pope, letters of, I, 5, I2, I $8,2 \mathrm{I}, 33,5 \mathrm{I}, 78$, IOI, IO2, $\mathrm{II}_{4}$

- orders concerning slaves, 84,87 , IOI

- receipts given by, 108, I 09 .

- ordinance of, 120

Gennadius, exarch of Africa, I $7,22,55 n$., $\mathrm{IO}_{4}$

Genoa, patrimony near, 13

Gentio, recruiting officer, 53 , 68,74

Germanicia, patrimony of, I7

Gratian, law of, $59 n$.

- Decretum, $120 n$.

Gregorovius, History of Rome, $123 n$.

Gregory the Great, Pope, Dialogues, $33 n ., 63,78$, $89 n ., 92 n .$, II 8 ., I19

- Letters (Registrum Epistolarum), 3, 4, 5, et passim

- II, Pope, 42 n., 48 ., 49, 50 n., 53 
Grisar, articles on patrimony, xvii-xix, $8 n ., \quad 9,20 n$. , $64 n ., 7 \mathrm{I} n ., 74$

guilds of bakers, $8 \mathbf{I}$

- of dyers, 89, I I $8 n$.

- of soap-boilers, 89, I $18 n$.

Hartmann, notes on Gregory's letters, 3I $n$., $128 n$.

Hauck-Herzog, Real-encyklopädie, 2 n., I $6 n$.

Hieronymus, defensor and rector of patrimony in Cottian Alps, 13

Hilary, deacon and rector of African patrimony, 17, 36 $n ., 98 n$.

Hippo, patrimony near, $\mathbf{r}$ ?

Honoratus, Saint, 78

Honorius, Emperor, law of, $60 n$.

- Pope, leases granted by. 50

horreae, barns, roo

Hunter, Introd. to Roman Law, $46 n$.

Hydruntum (Otranto), patrimony near, 9

Illyria, patrimony in, 6,18 , I9

imperial officials, xvi, I6, $2 \mathrm{I}$, 25, 71, 88, 94-106

imperial patrimony, 4

Innocent, Pope, I 6 n.

- praetorian prefect, I05

inquilinus, synonym of colonus, $54 n$.

Isaac, Saint, of Spoleto, I I9

Istria, patrimony in, I 3

Jaffé, RegestaPontificum, notes on pp. 5, I2, I4, I 8,22 , 24, 32, 40, 42, 44, 48, 49, $5 \mathrm{I}, 53,64,74,78,8 \mathrm{I}, 87$, roI, 102, I07, I09, I10, I I I, I I 2, I 4
Januarius, archbishop of Sardinia, 86

Jewish converts, I3I $_{3}$

- merchants, 89

Jews forbidden to keep Christian slaves, 85,86

- Gregory's attitude towards, 9o, 9I

John V, Pope, 96

John the deacon (Johannes Diaconus), Vita S. Gregorii, 8-18, II $5 n$, II $8 n$., I22, I26, I32, 133

- bishop of Syracuse, $26 n$., I08, II 3

- defensor, 24, $30 n$.

- notary and rector of Illyrian patrimony, 18

- praetorian prefect, Ioo, I26

- religiosus, 125

- sub-deacon and rector of Istrian patrimony, I3

Julian, bishop of Cingulum and rector of Picenum, 22, II 2

Justin, praetor of Sicily, 25 n., 99

Justinian, Emperor, laws of, I9, 38, 45, 47, 56, 57, 58, 83

(See also Codex Just. and Novellae Just.)

Latifundia, large estates, 42, 55

Latium, patrimony in, I2

Leo the Iconoclast, Emperor, $7 n$.

Leontius, ex-consul, 105, 106 $n$.

Liber Diurnus, quoted or referred to, $23 n$., $24 n$., $25 n$., $28 n ., 5$ I, 60 n., 83, 88, I I I, I 6 n., I22, I23 n., I24, I29

Liber Pontificalis, quoted or referred to, $4,22,96$, I $16 n$., $123 n$. 
Liberatus, merchant, $3 n$.

Libertinus, praetor of Sicily, 90,105

Licerius, bishop of Arles and rector of Gallic patrimony, I 4, I5, 22

Liguria, patrimony in, 13, 22, $36 n$.

locatio, form of lease, 46,47 , $52 n$.

Lombards, invasions by, xiii, $6,9,11,12,13,14,16,35$. 92,97

- rule preferred to imperial government, 70, 104, 106

- redemption of captives taken by, $88 n$., I I 7

- bought off by Gregory, II 7,130

Lucania, patrimony in, 8,70

Luitprand, King, xiii, I4

Magnus, priest of Milan, I3, 22

Malchus, bishop and rector of Dalmatia, 18, 22, 32

Manichees, in Sicily, 92

Mansi, Conciliorum Collectio, 102, 109, I IO

Marcian, a pseudo-defensor, 36

Marcus Aurelius, 54

marriage of sub-deacons forbidden, 23

- of defensors and notaries allowed, 23

- of slave with freewoman not recognised, 80

Marseilles, patrimony near, I4 massae, estates into which patrimony was sub-divided, $40,4 I, 60$

matricula, roll (of persons in receipt of poor relief), I2I, 122

matricularii, persons whose names were on the matricula, 29, 122, 123
Maurus, bishop of Praeneste, $27 n$.

Maximian, bishop of Syracuse and papal vicar, 3I

Maximus, Emperor, law of, $59 n$.

Melleus, sub-deacon, 8r, iro

Messina, 7, 33

Migne, Patrologia Latina, referred to in notes on $\mathrm{pp}$. I8, 27, 33, 5I, 8I, 84, 85, 87, IO7, IIO, II2, II 3

Milan, church of, 13, 22, 33, $34,100,120$

Misenum, bishop of, 99

mission, to England, I6

- to Corsica and Sardinia, r6, 91

Monasteries, 3 n., 82, 83, 84, 85

Montana, slave, 80,83

Naples, patrimony in, Io, II

- church of, 80 , IOO, I2I, I26

- guild of soap-boilers at, 89

Narses, official at Constantinople, 88

Nasas, Jew, 90

notaries, duties of, 14, 36, 107,123

- position of, 23

Nursia, patrimony in, I I

Novellae, of Justinian, notes on pp. $30,45,46,47,48,49$, . 79

Occelanus, tribune of Otranto, $9,97 n$.

oeconomi, officials of church of Constantinople, 38, 39

Optatus, rector of Nursian patrimony, II

originarius, colonus by birth, $54 n$.

Ortona, mentioned by Gregory, 10, $43 n$.

Otranto, patrimony round, 9 
Pagliari, church of, 70

Panormus (Palermo), 7, $46 n$.

Pantaleo, defensor, 73, I $13 n$.

- notary and rector of $\mathrm{Li}$ gurian patrimony, $13,36 n$.

Paschasius, bishop of Naples, I2I

Paterius, notary, 83

Paulus Diaconus, referred to, I 4

peculium, savings of slaves or of coloni, $4,6 \mathrm{r}, 62,80$

Pelagius I, Pope, $5 n$., 12, 14 , 22,27 n., 33, 35, 8I, IOI, IIO, II

- II, Pope, 7, I I, I4, 23

- of Tours, $15 n$.

pensio, payment made by coloni, $63-67,72,107$, I I I

Peter, Saint, church of (at Rome), 8, 27

- - relics of, 23

- notary, $36 \mathrm{n}$.

- sub-deacon and rector of Sicilian patrimony, 5,6 , 10, 24, 25 n., 27, 3I, 32, 37, 43 . 5I, 65-67, 9I $n$., 94, I24 $n$.

Picenum, patrimony in, $5 n$., $12,22,78$

Pimerius, bishop of Amalfi, 98

Pisaurum, citizen of, 125

Placidus, rector of Gallic patrimony, $\mathrm{I} 4$

polypticum, account book, II 5

Praeneste, bishop of, $27 n$.

priests, possession of property by, 4

- Candidus only priest appointed as rector, 23

Protasius, of Aix, $x_{5} n$.

rationes, accounts, 26

Ravenna, church of, $3 n$., 33 , I34

- exarch of, ro

- patrimony near, $13,36 n$.

rectors, position of, $2 \mathrm{I}-32, \mathrm{IO} 2$ rectors, relations with coloni, 6o-64

- names of, during Gregory's pontificate, 7-18

- receipt of revenue by, ro7II 2

recula, small field, 18

Romanus, notary and rector of Apulia, 9

- rector of Syracuse, $25 n$., $6 \mathrm{I}, \mathrm{I0} 8, \mathrm{II} 3$

- exarch, 104

Rome, city of, grants of corn to, 6, 27, 28, 99-101, I18, 125

- patrimony in, $x_{4}$

- population of, $\operatorname{Ir} 7, \operatorname{Ir} 8$

- division into districts, 123

- diaconiae in, 123-127

Rossi, Roma sotterranea cristiana, $123 n$.

Sabina, patrimony of, II, III Sabinus, rector of Sardinian patrimony, 17

salae, dwellings of herdsmen, 43

Salona, church of, 33

Salvian, De Guhernatione Dei, 56,70

Samaritans, at Catane, 86

Samnium, patrimony of, 9

Sapaudus, bishop of Arles, 14

Sardinia, patrimony of, 16,17

- slaves in, 82, 86, 9I, $\mathrm{r}_{30}$

- extortions of officials, 104

Savigny, Der römische Colonat, $55 n$., $59 n$., 6r, $62 n$., $75 n$., $\mathrm{x} 20 \mathrm{n}$.

- Uber die römische Steuerverfassung, $69 n$.

Savinus, bishop of Gallipoli, 9 - sub-deacon and rector of Bruttium, 8, 27

Scholasticus, defensor, ro, 77 scribo, recruiting officer, 53 , 97

scrinium, registry, 24,98 
Scylacaeum, castrum of, 98

Serenus, of Marseilles, $r_{5} n$.

Sergius, defensor and rector of Calabria, 9

Servus-dei, deacon and rector of Sicily, 7,67

Sicily, patrimony in, 5, 6, 7, $35,65,89,95$

- rector of, $7,27,31,35,38$, $44,71,72,89,94, I 32$

- refugees from Lombards in, $35, \mathrm{Ir}_{3}$

- Jews in, 90, 91

- pagans and heretics in, $9 r$, 92

- corn supplies from, 99, II, 125

Simplicius, Pope, I20 $n$.

sitonicum, granary, Ioo

slaves, property of, 4

- position of, 28, 79-89

- purchase of English, 15, 82

- Jewish, 86

Slavs, raids of, 13,18 solaticum, ground rent, 98 solidi, difference between Gallic and Roman, $15 n$.

- value of, 65, $77 n$.

Spain, papal envoy sent to, 30 n., 35

Spoleto, St Isaac of, I I9

Stephen, chartulary, ro3, ro4 sub-deacons, regionary, I4

- appointed as rectors, 23

- forbidden to marry by Pelagius II, 23

Symmachus, defensor and rector of Corsica and Sardinia, 17

Syracuse, patrimony in district of, 7

- bishop of, $26 n$., 108, II3

Syragius, of Autun, ${ }_{5} n$.

Talitanus, imperial official, 95

Tamnus, Jewish merchant, 89

Terracina, bishop of, $\mathbf{I} 2$
Terracina, tree-worshippers at, 12, $92 n$.

Theodore, consul, 95

Theodoric, King, privileges granted by, 34, 73

Theodosius, Emperor, see Codex Theodosianus

- imperial tax-collector, $7 \mathrm{r}$, 72

Theophanes, Chronographia, I9, 20

Theudebert, King, I $5 n$.

Theuderich, King, $5 n$.

Thomas, slave of church, 80 , 82,83

titulus, notice of ownership, 37 n., 104

Toledo, archbishop of, $30 n$.

Tomassetti, La Campagna Romana, 42, $55 n$.

Tours; Pelagius of, $15 n$.

Tres Tabernae, threatened by Lombards, 12

tributarius, synonym of colonus, $54 n$.

tributum, land-tax, 69, 70, 96

tuitio, protection (ecclesiastical), 29, 87

Tuscany, patrimony in, 12

Urbicus, defensor and rector of Sabine patrimony, II, III

usufruct, of church lands, $49 n$.

Valens, law of, $32,64 n$.

Valentinian, law of, 32, $64 n$.

Velletri, Lombards near, 12

Vergilius, of Arles, I5 n., $22 n$.

Vienne, Desiderius of, $15 n$.

Vigilius, mentions patrimony of Praevalitana, 18

vilicilia, small payment to vilicus, 67

vilicus, agent who collected pensio from coloni, 67 
Vincomalus, receipt from Gelasius to, 26

Vitalis, defensor and rector of Sardinia, 16, 17

Wetzer-Kaulen, Kirchenlexikon, 2 n., II6n.

xenodochium, church infirmary, 29, 44, 127-1 30

xenodochus, official in charge of a xenodochium, I29, I30

Xystus, Pope, 4

Zaccaria, De Patrimonio, 9, ro $n .$, I4 $n .$, I9 $n$., III, II $2 n$. Zacharias, Pope, leases granted by, 49,50

Zeia, count, letter to, Ior

Zittanus, magister militum of Sicily, 95 




\section{UNIVERSITY OF CALIFORNIA LIBRARY BERKELEY}

Return to desk from which borrowed.

This book is DUE on the last date stamped below.

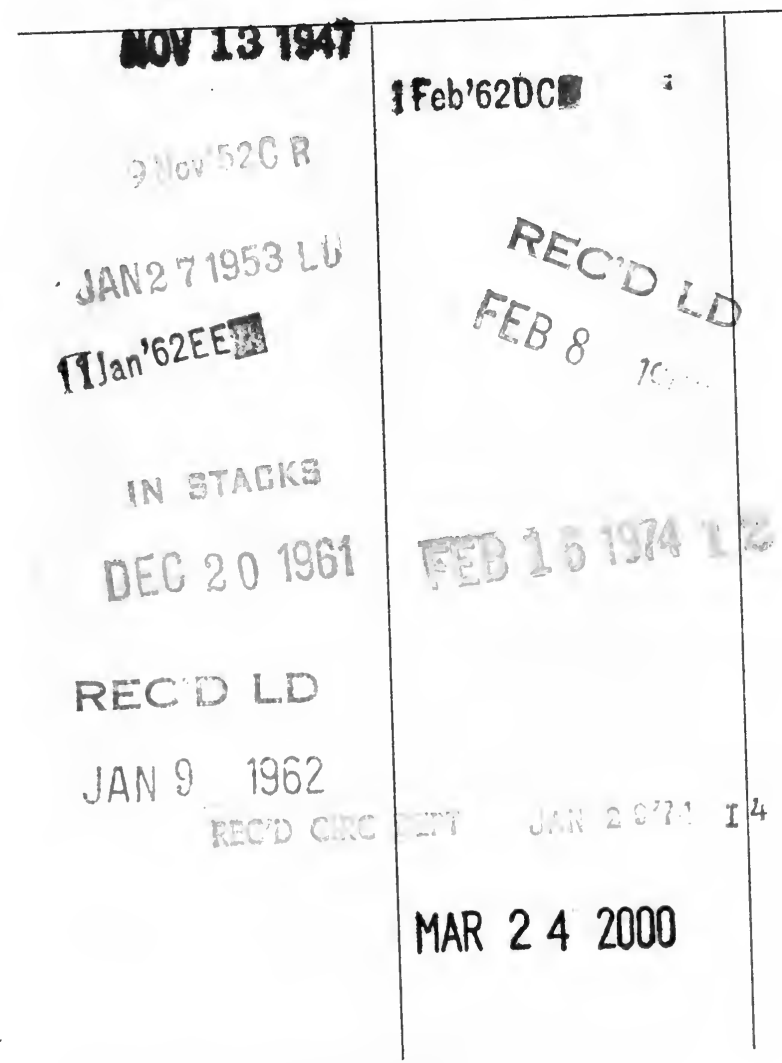

LD 21-100m-9,'47(A5702s16) 476 


$$
\begin{gathered}
(35945 \\
8 \times 1950 \\
87
\end{gathered}
$$

\section{UNIVERSITY OF CALIFORNIA LIBRARY}



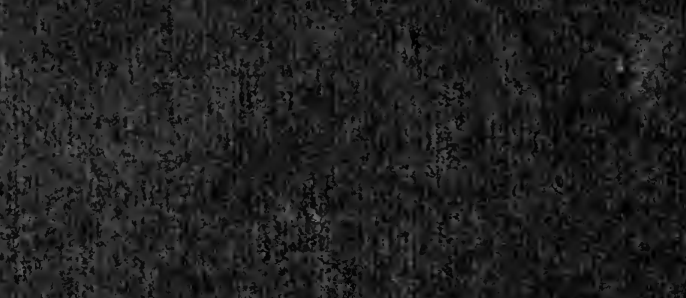

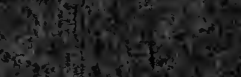

intis sing
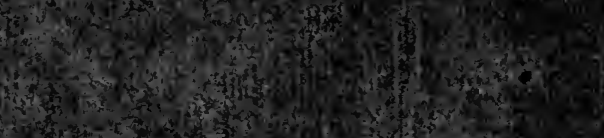

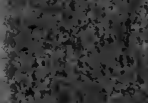
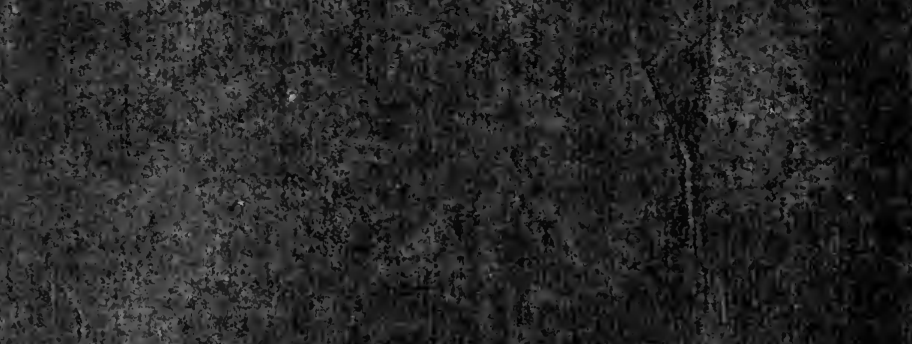

As

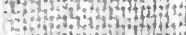

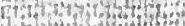

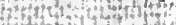

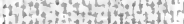

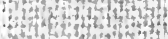

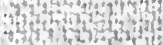

Wivition

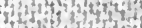

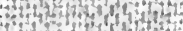

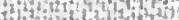

4.

3.t.

no

s.

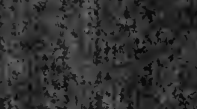

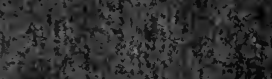

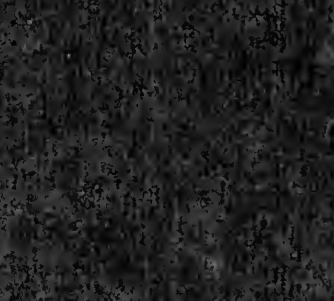

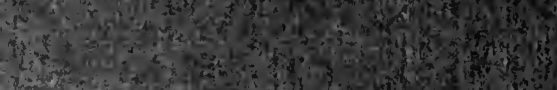

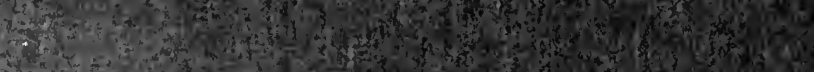

